\title{
APLICAÇÃO DE GEOPROCESSAMENTO PARA O AUMENTO DA EFICIÊNCIA DE PERCURSO EM OPERAÇÕES AGRÍCOLAS NA CULTURA DA CANA-DE-AÇÚCAR (Saccharum spp.)
}

\author{
RODRIGO VELLARDO GUIMARÃES
}

\begin{abstract}
Dissertação apresentada à Escola Superior de Agricultura "Luiz de Queiroz", Universidade de São Paulo, para obtenção do título de Mestre em Agronomia, Área de Concentração: Máquinas Agrícolas.
\end{abstract}

PIR A C I C A B A

Estado de São Paulo - Brasil

Setembro - 2004 


\title{
APLICAÇÃO DE GEOPROCESSAMENTO PARA O AUMENTO DA EFICIÊNCIA DE PERCURSO EM OPERAÇÕES AGRÍCOLAS NA CULTURA DA CANA-DE-AÇÚCAR (Saccharum spp.)
}

\author{
RODRIGO VELLARDO GUIMARÃES \\ Engenheiro Agrônomo
}

Orientador: Prof. Dr. JORGE GUSTAVO DA GRAÇA RAFFO

Dissertação apresentada à Escola Superior de Agricultura "Luiz de Queiroz", Universidade de São Paulo, para obtenção do título de Mestre em Agronomia, Área de Concentração: Máquinas Agrícolas.

PIR A CICABA

Estado de São Paulo - Brasil

Setembro - 2004 


\section{Dados Internacionais de Catalogação na Publicação (CIP) DIVISÃO DE BIBLIOTECA E DOCUMENTAÇÃO - ESALQ/USP}

\section{Guimarães, Rodrigo Vellardo}

Aplicação de geoprocessamento para o aumento da eficiência de percurso em operações na cultura da cana-de-açúcar (Saccharum spp.) / Rodrigo Vellardo Guimarães. - - Piracicaba, 2004.

82 p. : il.

Dissertação (mestrado) - - Escola Superior de Agricultura Luiz de Queiroz, 2004.

Bibliografia.

1. Aerofotos 2. Agricultura de precisão 3. Cana-de-açúcar 4. Geoprocessamento 5. Mecanização agrícola 6 . Microbacia hidrográfica 7. Sistema de informação geográfica 8. Software I. Título

CDD 631.3 
"Caminhante, não há caminho, faz-se o caminho ao andar..."

Antonio Lopes

Aos meus pais, que sempre me apoiaram, Vradinir e Anita, À minha filha Luna, que ilumina minha vida, Minha irmã, Luciana, sempre atenciosa e leal amiga, Meus sobrinhos, Letícia e Rennan, que são a alegria da família...

Dedico. 


\section{AGRADECIMENTOS}

Ao meu orientador, professor Dr. Jorge Gustavo da Graça Raffo (ESALQ/USP), pela minha aceitação, orientação e confiança ao longo destes anos;

Ao professor Luiz Geraldo Mialhe (ESALQ/USP), pela entusiasmada orientação, que foi fundamental para a execução deste estudo;

Aos Professores da ESALQ, Prof. Dr. Valdemar Antonio Demétrio, Prof. Dr. Edgar Gomes Ferreira de Beauclair, Prof. Dr. Thomaz Caetano Canavam Ripoli, Prof. Dr. José P. Molin, Prof. Dr. Marcos Milan, pelas sugestões e críticas, construtivas;

Ao Prof. Dr. Casimiro Dias Gadanha Junior, coordenador do programa de Pós-Graduação de Máquinas Agrícolas pela confiança e pela inestimável ajuda para a conclusão de minha Dissertação;

A Prof. Dra. Sonia Maria Stefano Piedade, pela ajuda nas análises estatísticas; Ao meu amigo, André Marcondes Andrade Toledo, do laboratório de geoprocessamento do CENA/USP, pelo fornecimento dos mapas vetoriais de hidrografia, estradas, solos e ; Ao Engenheiro Agrônomo José Eduardo Bove (CATI), pela incalculável colaboração para a coleta de dados, fornecimento de mapas e pelo acompanhamento de campo na microbacia dos Marins;

Ao Eng. Agrônomo José Carlos Conde (COOPERSUCAR), pelos esclarecimentos e pela atenção;

Ao Eng. Agrônomo, Arnaldo Bortoletto e ao Eng. Agrônomo Marcos Farhat da COPLACANA pela colaboração no fornecimento do mapa de talhões.

Ao Eng. Agrônomo Ricardo Peres (FCA/UNESP), pela ajuda na elaboração dos mapas temáticos;

Aos meus amigos e colegas do departamento de Máquinas Agrícolas pelos muitos momentos de alegria e descontração;

Aos funcionários do departamento de Engenharia Agrícola, Dona Lurdes, Fernanda, Juarez, Áureo, Chicão, Jezuíno, Sandra, Davilmar e Carlos, que ajudaram em todos os momentos Aos funcionários da Biblioteca Central da ESALQ/USP, que me ajudaram nas correções 


\section{SUMÁRIO}

\begin{tabular}{|c|c|c|}
\hline \multicolumn{3}{|c|}{ SUMÁRIO } \\
\hline & & Página \\
\hline \multicolumn{2}{|c|}{ LISTA DE FIGURAS... } & ix \\
\hline \multicolumn{2}{|c|}{ LISTA DE TABELAS........ } & $x i$ \\
\hline \multicolumn{2}{|c|}{ RESUMO..................... } & xii \\
\hline \multicolumn{2}{|c|}{ SUMMARY... } & xiv \\
\hline 1 & INTRODUÇÃO......................... & 1 \\
\hline 2 & 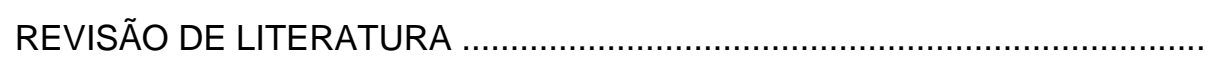 & 2 \\
\hline 2.1 & 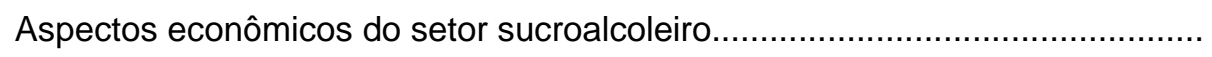 & 2 \\
\hline 2.1 .1 & Perspectivas para o setor & 3 \\
\hline 2.2 & 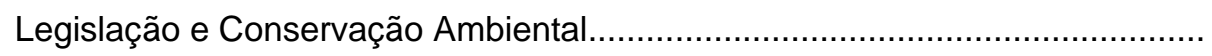 & 5 \\
\hline 2.2 .1 & Queimada em canaviais.............................. & 5 \\
\hline 2.2 .1 & Código Florestal...................... & 5 \\
\hline 2.2 .3 & Áreas de Proteção Ambiental... & 6 \\
\hline 2.2 .4 & Controle de erosão em estradas rurais e carreadores.............. & 7 \\
\hline 2.3 & 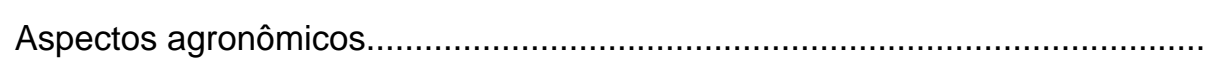 & 9 \\
\hline 2.3.1 & Clima e Solo............................. & 9 \\
\hline 2.3.2 & 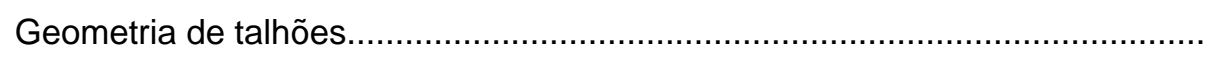 & 11 \\
\hline 2.3.3 & 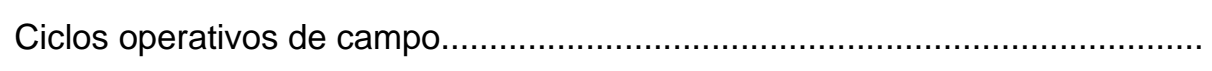 & 13 \\
\hline 2.4 & Sensoriamento Remoto......... & 15 \\
\hline 2.4 .1 & Tipos de sensores..................... & 15 \\
\hline 2.4 .2 & Resolução de uma imagem..... & 16 \\
\hline 2.4 .3 & Fotogrametria.......................... & 17 \\
\hline 2.5 & 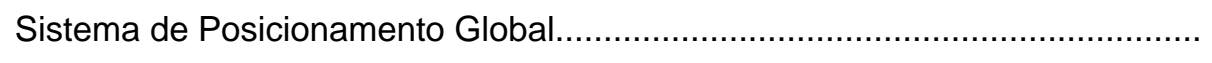 & 17 \\
\hline 2.5 .1 & Método diferencial de Posicionamento (DGPS) & 18 \\
\hline 2.5 .2 & GPS e banco de dados espaciais. & 19 \\
\hline 2.6 & Sistema de Informações Geográficas.................... & 19 \\
\hline 2.6 .1 & SIG aplicado ao planejamento rural..... & 20 \\
\hline
\end{tabular}




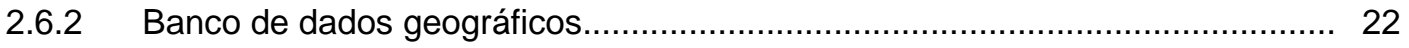

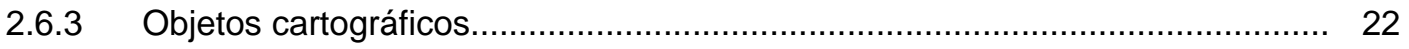

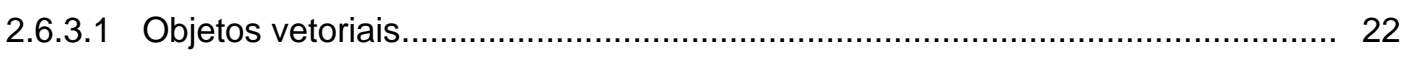

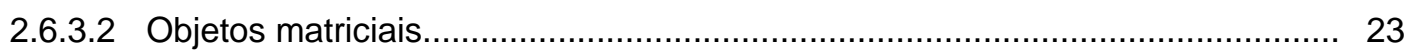

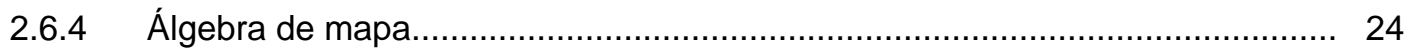

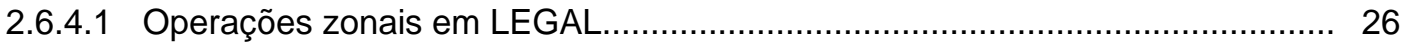

2.6.4.2 Operações algébricas pontuais................................................................. 27

$2.6 \quad$ Processamento digital de imagens........................................................... 28

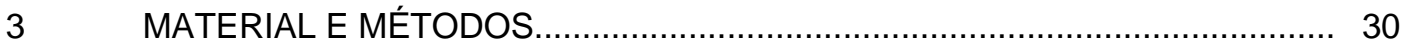

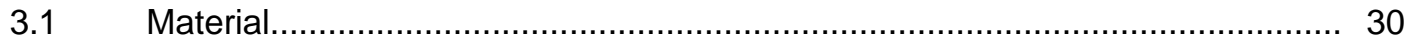

3.1.1 Caracterização da área de estudo....................................................... 30

3.1.2 Equipamentos e programas computacionais................................................. 32

3.1.3 Sistema de coordenadas e projeção......................................................... 32

3.1.4 Categorias e planos de informação........................................................... 32

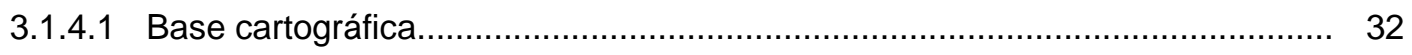

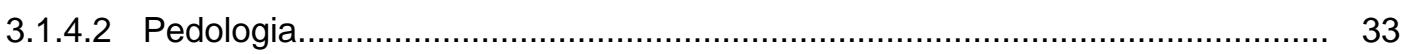

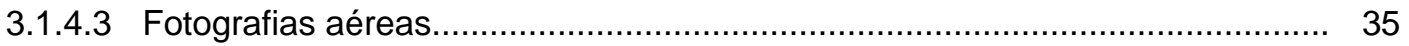

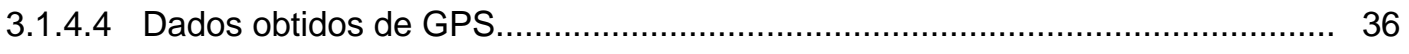

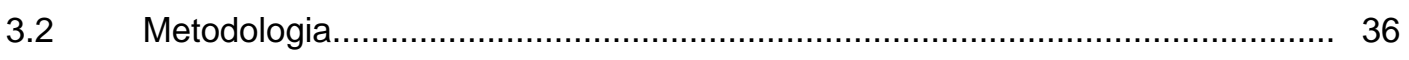

3.2.1 Atividades preliminares.......................................................................... 38

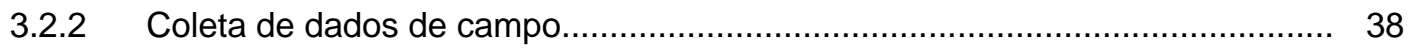

3.2.3 Entrada das imagens no SIG .......................................................... 38

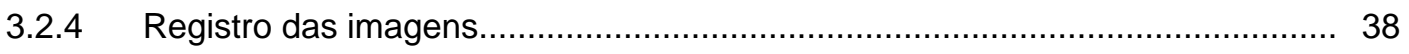

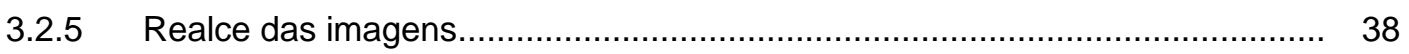

3.2.6 Análise das fotografias aéreas................................................................... 39

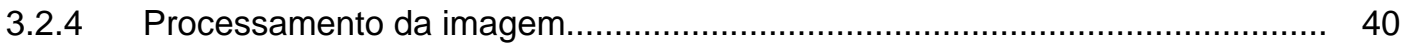

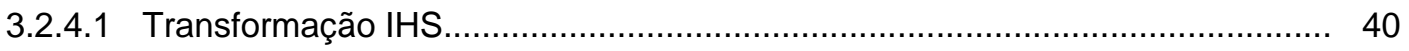

3.2.4.2 Segmentação da banda H................................................................. 40

3.2.4.3 Classificação da imagem realçada e segmentada.......................................... 40

3.2.4.4 Classificação supervisionada do mapa de solos............................................. 41 
3.2.4.5 Avaliação do mapeamento................................................................... 41

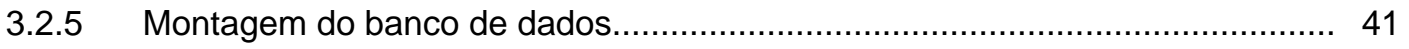

3.2.6 Digitalização das curvas de nível................................................................ 42

3.2.7 Vetorização de polígonos............................................................................... 44

3.2.8 Cruzamento dos planos de informação........................................................ 44

3.2.9 Critérios teóricos para a elaboração das Pl's.................................................. 46

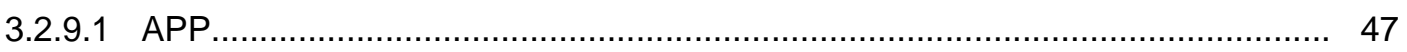

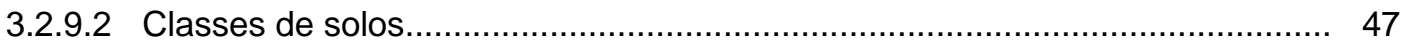

3.2.9.3 Formato e tamanho dos talhões................................................................. 47

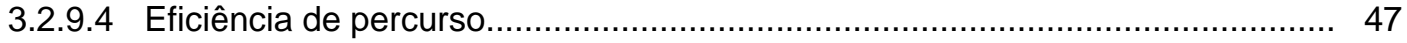

3.2.9.5 Planejamento da base física............................................................ 48

3.2.9.6 Limitações físicas................................................................................... 48

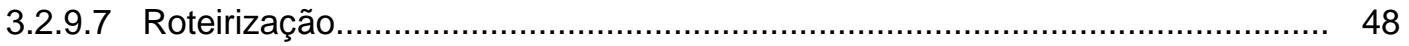

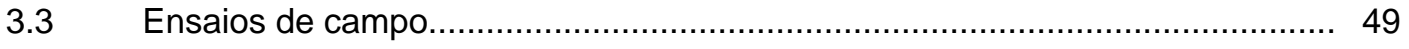

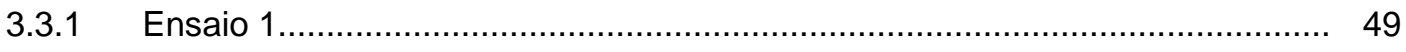

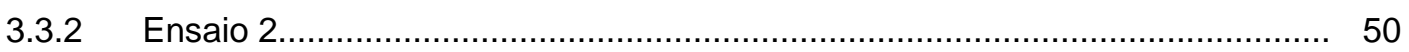

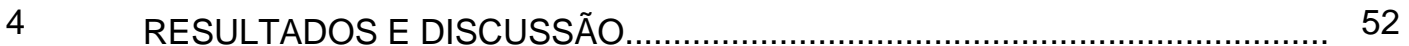

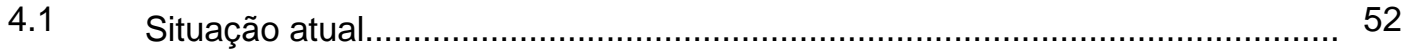

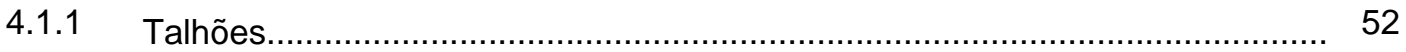

4.1.2 Carreadores e estradas vicinais............................................................... 55

4.1.3 Vegetação remanescente..................................................................... 56

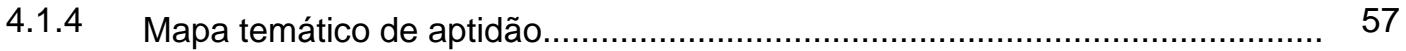

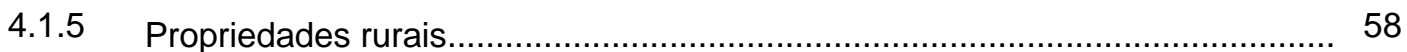

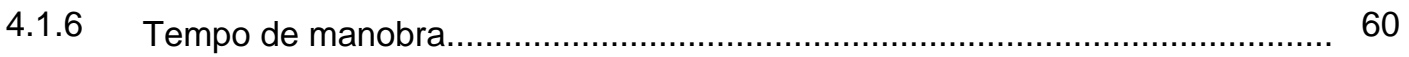

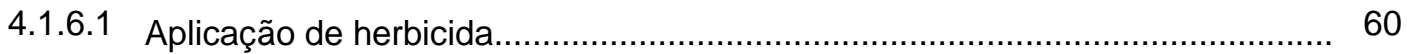

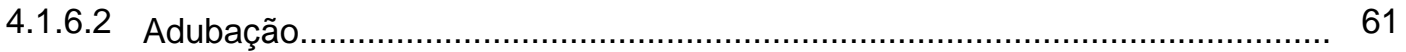

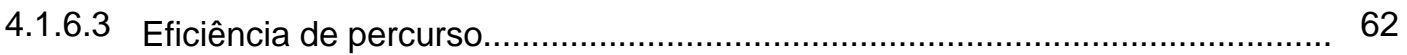

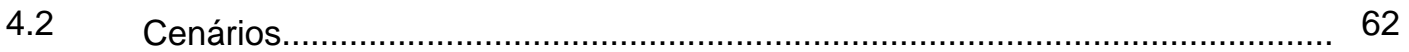

4.2.1 APP

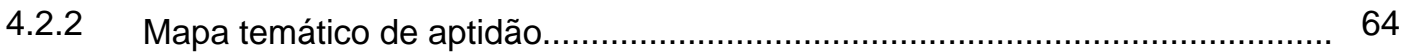

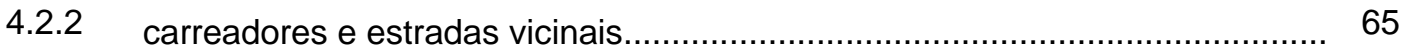

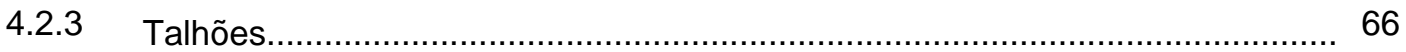

4.2.4 Intersecção entre propriedades e talhões.................................................... 68

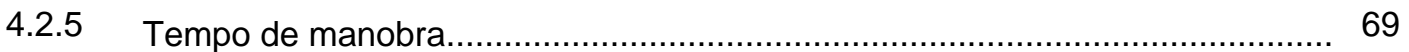

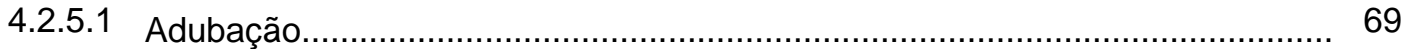

4.2.5.2 Aplicação de herbicida........................................................................ 70 
4.2.5.3 Cenário de Eficiência de percurso............................................................... 71

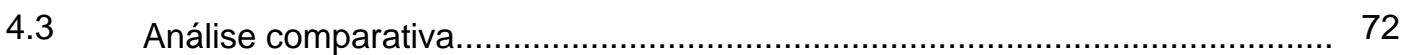

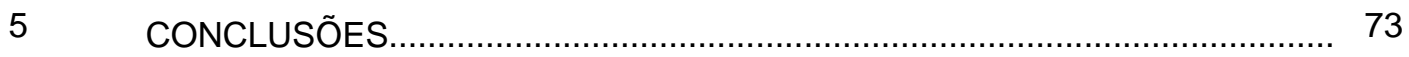

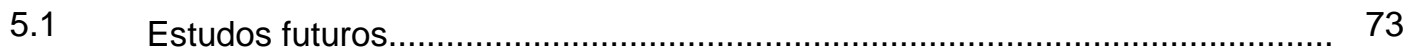

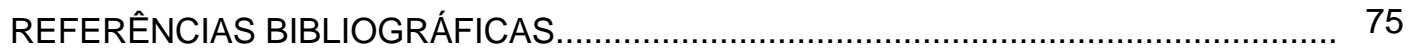




\section{LISTA DE FIGURAS}

Página

1 Formato de talhões

Fonte: (adaptado de Mialhe, 1974)

2 Ciclo de operação de campo unidirecional para preparo de solo

Fonte: (adaptado de Mialhe, 1974)

3 Ciclo operacional aberto para preparo de solo

Fonte: (adaptado de Mialhe, 1974).....

4 Esquema para a análise do ciclo operativo unidirecional fechado, de sentido horário, para gradagem em faixas alternadas (adaptado de Mialhe, 1974).....

5 Esquema de um SIG aplicado em um processo de planejamento.

Fonte: Adaptada de Aronoff (1989)

6 Objetos topológicos

7 Operação de maioria zonal. Fonte: Barbosa (1997)

8 Programa em LEGAL que integra dados matriciais e atributos de bancos de dados.Fonte: Matteo 1998)

9 Integração de planos de informação através de operação algébrica pontual Fonte: Adaptada de Aronoff (1989)............................................................. 27

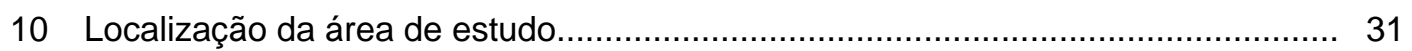

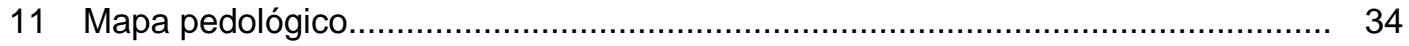

12 Imagem proveniente de mosaico de fotografias aéreas...................................... 35

13 Fluxograma da metodologia aplicada............................................................ 38

14 Categorias e Pl's do banco de dados do sistema............................................... 41

15 Metodologia para a obtenção de mapa de declividade.......................................... 43

16 Programa em LEGAL para a obtenção do mapa de aptidão na área total de cana 45 
17 Programa em legal para determinação da porcentagem da área dos talhões 26, 27 e 28 que estão presentes na propriedade 119............................................... 45

18 Cruzamento dos planos de informação........................................................... 46

19 Talhões identificados na área de estudo............................................................ 53

20 Representação gráfica do tamanho dos talhões observados na área de estudo..... 54

21 Traçado de carreadores e estradas vicinais........................................................ 55

22 Vegetação remanescente da área de estudo................................................... 56

23 Mapa de aptidão da área de cana-de-açúcar..................................................... 57

24 Propriedades rurais da região da área de estudo............................................ 58

25 Tamanho (ha) das propriedades rurais presentes na área de estudo.................... 59

26 Tempo estimado em manobras de cabeceira para operação de aplicação de

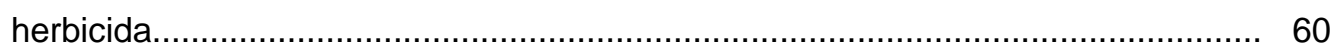

27 Tempo estimado de manobra para adubação................................................... 62

28 Eficiência de percurso dos talhões presentes na área de estudo............................ 63

29 Cenário de Área de Preservação Permante (APP) ................................................... 63

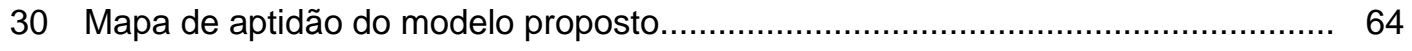

31 Alternativa de traçado de carreadores ao modelo atual........................................6 65

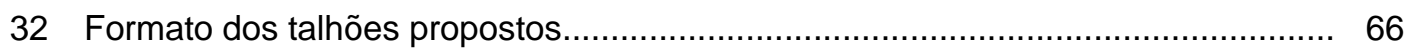

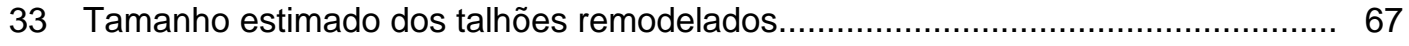

34 Área de três talhões que tem intersecção com uma propriedade............................ 69

35 Tempo estimado de manobra para o cenário de talhões propostos - operação:

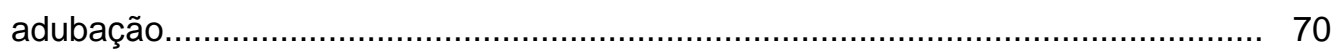

36 Cenário de tempo de manobra para aplicação de herbicida................................... 71

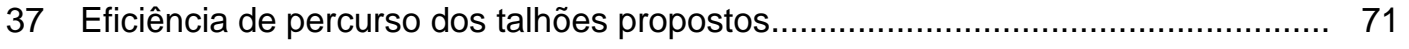

38 Sobreposição das camadas, declividade, cenários de carreadores, APP, hidrografia e cenário de talhões....................................................................... 73 


\section{LISTA DE TABELAS}

Página

1 Classes de solos.

2 Ensaio de campo para a observação do tempo médio gasto com manobras de cabeceira para a operação de aplicação de herbicida.....

3 Tempo de manobra observado no campo para a aplicação de herbicida.

4 Ensaio de campo para a observação do tempo médio gasto com manobras de cabeceira para a operação de adubação.............................................................. 50

5 Tempo de manobra em uma operação de adubação............................................... 51

6 Dados dos talhões observados por sensoriamento remoto.................................... 54

$7 \quad$ Aptidão da área na qual é cultivada cana-de-açúcar............................................ 57

8 Dados estatísticos das 73 propriedades rurais, presentes na área de estudo........ 59

9 Tempo estimado de manobra para a aplicação de herbicida para os 189 talhões

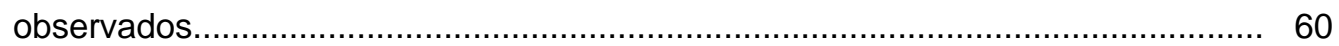

10 Tempo estimado de manobra para adubação em 189 talhões................................ 61

11 Eficiência de percurso dos 189 talhões observados na área de estudo.................. 62

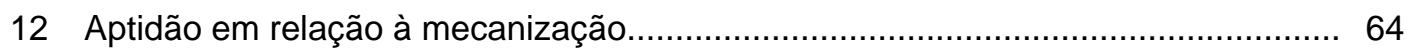

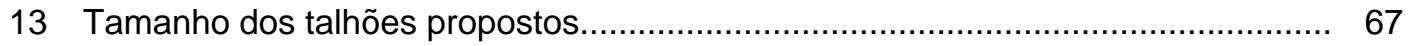

14 Exemplo da aplicação do algoritimo em LEGAL: Área de três talhões presentes

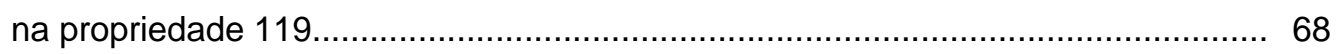

15 Tempo estimado com manobras de cabeceira para a operação de adubação, no cenário dos 81 talhões propostos..

16 Tempo de manobra estimado para aplicação de herbicida nos 81 talhões projetados com os critérios propostos......................................................... 69

17 Estatística descritiva da EP\% no cenário proposto para 81 talhões...................... 71

18 Comparação entre o modelo adotado e o cenário proposto................................. 72 


\title{
APLICAÇÃO DE GEOPROCESSAMENTO PARA O AUMENTO DA EFICIÊNCIA DE PERCURSO EM OPERAÇÕES AGRÍCOLAS NA CULTURA DA CANA-DE-AÇÚCAR
}

(Saccharum spp.)

\author{
Autor: RODRIGO VELLARDO GUIMARÃES \\ Orientador: Prof. Dr. JORGE GUSTAVO DA GRAÇA RAFFO
}

\section{RESUMO}

A utilização de máquinas e implementos agrícolas nas culturas anuais ou semiperenes no Brasil, é um dos fatores que mais demandam recursos financeiros, devido ao custo em combustíveis, mão-de-obra e depreciação das máquinas. Além disso, se mal utilizadas, pode acarretar danos ambientais, como erosão e compactação do solo. A agricultura de precisão vem crescendo no Brasil e o princípio é o controle de fertilidade, assim como de atributos físicos e químicos que interferem na produtividade de áreas específicas. Partindo deste pressuposto, as zonas de manejo, delimitadas por áreas geométricas, são definidas pelo administrador, pelos fatores físicos e químicos do solo, assim como sócioambientais. A hipótese deste trabalho foi que "A geometria dos talhões pode influenciar diretamente a eficiência de percurso". O objetivo deste trabalho foi criar uma base de dados geográficos que subsidiasse a avaliação da geometria dos talhões e o traçado dos carreadores, em uma região canavieira. A área de estudo se localiza na microbacia do Ribeirão dos Marins, município de Piracicaba, estado de São Paulo. O software utilizado para o georreferenciamento das imagens, cruzamento dos mapas, elaboração de MNT, e criação do banco de dados foi o SPRING, desenvolvido pelo Instituto Nacional de Pesquisas Espacias (INPE). Foram utilizadas fotografias aéreas para a identificação dos talhões, carreadores, estradas vicinais e rede de drenagem, para a elaboração de mapas temáticos a serem inseridos no sistema. Os mapas de curvas de nível, uso do solo e classe de solo em formato vetorial subsidiaram a elaboração dos 
mapas temáticos de ambientes de produção. Com a metodologia utilizada, foi proposto um cenário de talhões, com base nos critérios inseridos no sistema, e calculados; o comprimento dos carreadores, a área de preservação permanente, o tempo de manobra de máquinas agrícolas de duas operações agrícolas, assim como a eficiência de percurso. Este cenário,foi comparado com a situação atual, para que fosse estabelecido quanto a geometria influenciou nos aspectos estudados. 


\title{
APLICATION OF GEOPROCESSING FOR INCREASE THE WAY EFICIENT ON THE AGRICULTURAL MACHINES OPERATIONS ON THE SUGAR CANE (Saccharum spp.) CROP
}

\author{
Author: RODRIGO VELLARDO GUIMARÃES \\ Adviser: Prof. JORGE GUSTAVO DA GRAÇA RAFFO
}

\section{SUMMARY}

The use of machines and agricultural implements in cultures annual or semi-perennial in Brazil is one of the factors that more demands financial resources, due to the cost in fuels, labor and machinery depreciation. Besides, if badly used, can happen environmental damages, such as erosion and compacting soil. Precision Agriculture is growing in Brazil and it is based on soil physical and chemical attributes as well other factors that interfere in the productivity of specific areas. From this stand point, the geometric shapes field, which are influenced by soil environmental and social factors, have a fundamental role in the optimization of the productive processes, influencing directly in the income of the producer. The planning of the shape of the fields and roadways with the use of Geographical Information System (GIS) and Remote Sensing techniques contribute to the optimization of traffic, improving the course efficiency, reducing the number of the machine hours and fuel and labor costs, minimizing the environmental impacts. The present work aimed at using GIS and Remote Sensing to obtain field and roadways maps for the sugarcane crop. The area studied was the Marins drainage basin, located in the city of Piracicaba, São Paulo state. The software used for images georeferencing, map crossing and TIN elaboration was SPRING, developed by INPE (Instituto de Pesquisas Espaciais). Aerial pictures were used for the identification of the fields, roadways, local highways and watersheds, in order to elaborate thematic maps to insert in the system. Contour, land use and soil type in vector format subsidize the elaboration of thematic maps of production scenarios. The information layers were crossed using LEGAL (Linguagem Espacial de Geoprocessamento Algébrico) programming. With this methodology, fields 
scenarios were proposed, based on criteria insert in the system. The roadway length, the reserve forest, steering time of two agricultural operations, the intersection of plots and farm boundaries and traffic efficiency were calculates. Thus, it was possible simulate an optimized scenario with higher traffic efficiency. This scenario, compared to the currently adopted plot design, would accomplish a decrease in the roadway length steering time, machine hours and increase in the area cultivated. 


\section{INTRODUÇÃO}

A agricultura paulista lidera a produção de cana-de-açúcar no País, tendo produzido em 2002, 59\% da produção total do Brasil. O cenário econômico para os próximos anos é promissor, e a necessidade de aumentar a produção para atender a demanda está contribuindo para novos investimentos no setor.

Apesar das perspectivas serem favoráveis, algumas regiões com tradição no plantio de cana-de-açúcar estão passando por modificações, de acordo com a nova legislação paulista (Lei $n^{\circ} 11.241$ de 19/02/02) que regulamenta a queima em canaviais no estado, restringindo as áreas onde não possam ser realizadas operações de colheita mecanizada. Para Sparovek, (1997) a situação da proibição de queimadas de cana afetaria, na região de Piracicaba, 45.200 ha, que se localizariam em solos inaptos para a mecanização da colheita, de um total de 86.799 ha. Além disso, devido ao alto custo de produção (devido à indexação dos insumos ao dólar) e o elevado preço das terras no estado de São Paulo, a adoção de estratégias que permitam incrementar o rendimento financeiro é uma necessidade para garantir a oferta dos produtos oriundos da cana-de-açúcar.

A hipótese deste estudo é a de que "a geometria dos talhões pode influenciar a eficiência de operações agrícolas". A área de estudo desta Dissertação situa-se na microbacia do Ribeirão dos Marins, localizada na cidade de Piracicaba, Estado de São Paulo, com latitude aproximada de s $22^{\circ} 48^{\prime} 35^{\prime \prime}$, e longitude aproximada de o 47 43' 14". O objetivo deste trabalho foi utilizar técnicas de Geoprocessamento para avaliar a geometria dos talhões e o traçado dos carreadores e propor uma metodologia que aumente a eficiência de percurso de duas operações agrícolas em uma região canavieira. 


\section{REVISÃO DE LITERATURA}

Neste capítulo é apresentado o embasamento teórico dos critérios utilizados para o estudo de talhões e carreadores na cultura da cana-de-açúcar, utilizando técnicas de geoprocessamento. São abordados tópicos de legislação ambiental, aspectos gerais da cultura estudada, geomorfologicos, eficiência de percurso, ambientes de produção, Sistema de Informações Geográficas e Sensoriamento Remoto.

\subsection{Aspectos econômicos do setor sucroalcooleiro}

Um dos primeiros produtos brasileiros a ser exportado foi a cana-de-açúcar. Nos séculos XVI e XVII, o Brasil já era um dos maiores exportadores mundiais de açúcar. Segundo Arruda (1996), às condições favoráveis de solo e clima para o desenvolvimento da cultura, constituiu-se na principal causa da ocupação territorial brasileira.

Da área colhida no Brasil em 2002, de aproximadamente, 4,7 milhões de ha, 50\% estavam localizadas no Estado de São Paulo, que produziu 59\% da cana-de-açúcar, representando mais de duzentos milhões de toneladas, com uma produtividade física de 80 t/ha, a mais alta do país FNP (2002). A liderança de São Paulo também se firmou na exportação de açúcar, notadamente na década de 1990, que de 1\% em 1990/91, passou para 62,8\% em 1996, o que significou sair de 13 mil para 3,1 milhões de toneladas em cinco anos. Na produção de álcool manteve sua participação histórica de maior produtor nacional, operando na faixa de $60 \%$. Além disso, a cultura da cana-de-açúcar é a atividade mais importante na demanda pela força de trabalho na agricultura paulista, ocupando, em 1993, 40,6\% do total, crescendo para quase a metade em 1996, mesmo com queda de $10 \%$ na demanda total (SEADE, 1996, e SEADE, 1997). Para Balsadi (1995), o problema que se coloca é justamente a grande dependência na geração de emprego focada nas condições de desenvolvimento de, praticamente, uma atividade que, além das influências das condições gerais da economia derivadas do processo de desregulamentação a que está submetida - e do mercado externo, 
passa por um aprofundamento em seu processo de transformação tecnológica, com reflexos reducionistas na utilização de mão-de-obra Veiga Filho et al. (1995).

\subsubsection{Perspectivas para o setor}

De acordo com MAPA (2003), a lei regulamentada pelo Ministério do Meio Ambiente japonês faculta o uso da mistura de álcool à gasolina, a partir de março de 2004, nas regiões de Osaka e da Ilha Hokaido. De 2005 em diante, essa norma valerá para todo o país. Análises do governo do Japão comprovam que a adição até $10 \%$ de etanol não compromete a mecânica da sua frota de veículos, que consome 60 bilhões de litros/ano de gasolina. Além do álcool, o governo japonês está interessado no seqüestro de carbono e produção de biodiesel. As novas áreas de canaviais poderiam servir para o seqüestro de carbono, pelo qual o Japão pagaria, e para o cultivo de produtos dos quais se extraiam óleo para misturar no diesel. Anualmente, aquele país tem um estoque de crédito de US\$ 7 bilhões para investimentos no Brasil. Parte dos recursos pode ser usada no programa que está sendo analisado pela Câmara Setorial do Açúcar e do Álcool (MAPA, 2003).

Para que o setor possa atender a demanda, o aumento da área produtiva, inclusive em áreas não aptas para a colheita mecanizada, vem acarretando um debate entre ambientalistas e usineiros; as operações de queima prévia do canavial. Do total da área de cana-de-açúcar colhida no país, aproximadamente $75 \%$ é colhida no sistema de corte manual com queima prévia e $25 \%$ no sistema de corte mecanizado. A queima dos canaviais é amplamente praticada, pois aumenta o desempenho agrícola das colheitas manuais e mecanizadas Veiga Filho (1998).

Entretanto, grupos de ambientalistas, assim como de boa parte da opinião pública, considera que a queima de canaviais é extremamente nociva à saúde humana, assim como altamente impactante ao ambiente (Saturnino \& Landers, 1997).

A mudança na etapa do corte, de manual para mecânico, não é apenas uma mera substituição de uma técnica por outra; em operações agrícolas significa mesclar e otimizar cinco aspectos (Sugar \& Sweetener, 1996):

- o preparo do solo na lavoura;

- o dimensionamento dos equipamentos no campo;

- a equipe de manutenção e apoio;

- o treinamento do pessoal envolvido;

- alterações no transporte e na recepção da cana na indústria. 
O sistema de colheita é composto por três subsistemas: o sub-sistema de corte e carregamento, o sub-sistema de transporte e o sub-sistema de recepção. Cada subsistema tem interfaces que incluem aspectos comuns, os quais estabelecem um fluxo da matéria-prima do campo à indústria e que precisam ser alterados para compor-se ao novo arranjo técnico (Rípoli \& Paranhos, 1987).

Para Veiga Filho (1998), a questão fica mais complexa ao incluir os fatores sociais que causam impactos na demanda de mão de obra, e outras questões que subsidiem as reformulações no processo de produção. Devido aos fatores acima citados, o processo de mecanização no Brasil, e em particular no Estado de São Paulo, tem sido lento e pouco difundido. Segundo Toledo, et al. (1991) o índice de mecanização para a safra 1989/90, que 19\% da área mecanizável de cana-de-açúcar era colhida mecanicamente. A mesma estimativa, feita oito anos depois, para a safra 1997/98, em 69 usinas que representaram 46\% da área colhida em São Paulo, mostram um índice de mecanização de 17\% para o Estado, e de 29\% para a região canavieira de Ribeirão Preto (Comissão Tëcnica, 1997), muito baixos quando comparados com os $100 \%$ de mecanização do corte na Austrália e na Lousiana (EUA), por exemplo.

Weick (2001) estudando as mudanças e direções da tecnologia do agronegócio em 2010 cita que grandes inovações irão mudar o panorama internacional e dentre elas quatro tecnologias serão as mais importantes, sendo: Sistema de Posicionamento Global (GPS), Sistema de Informações Geográficas, Biotecnologia e informática aliada à internet. Já Ascoug et al. (1999) em uma análise do uso do computador por agricultores norte-americanos, citam que a adoção do computador nas propriedades agrícolas depende de alguns fatores, a saber; nível de escolaridade do produtor, idade do produtor, tamanho da propriedade, preço do produto agrícola produzido e diversificação das atividades, sendo que em grandes propriedades mais de $86 \%$ delas utilizam computador e que pequenos produtores este número reduz drasticamente, sendo que a grande maioria não utiliza deste recurso, contudo a maioria dos produtos agrícolas comercializados vem de propriedades que utilizam recursos computacionais. Os mesmos autores citam que aqueles que adotam o uso de computadores solicitam o desenvolvimento de programas que auxiliem na tomada de decisão, para que a possibilidade de erros seja minimizada.

Antunes \& Angel (1996) citam que os recursos computacionais devem ser encarados pelos agricultores como um fator de produção adicional e que deve ser adotado caso traga benefícios financeiros compensadores. 


\subsection{Legislação e conservação ambiental}

\subsubsection{Queimada em canaviais}

De acordo com a a revista Gleba (2002), a Lei $\mathrm{n}^{\circ} 10.547 / 00$ relativa ao uso agrícola do fogo no Estado de São Paulo, e regulamentada pelo Decreto $n^{\circ} 48.869 / 01$, que prevê a eliminação do fogo na colheita da cana no prazo de 30 anos, a restrição deve ser feita de forma gradativa, em conjunto com políticas de reciclagem e aproveitamento da mão-de-obra do setor sucroalcooleiro. Com isso, a mecanização ou colheita verde, segundo a revista Gleba (2002), deve ser realizada somente em declives inferiores a 12\%. Só no Estado de São Paulo, esta limitação inviabilizaria cerca de $45 \%$ da área plantada de cana, ou seja, dos 2,8 milhões de hectares, aproximadamente um milhão estaria acima de 12\% de declividade, sendo imprópria para a mecanização da colheita.

Para Sparovek (1997) a situação da proibição de queimadas de cana afetaria, na região de Piracicaba, 45.200 ha, que se localizariam em solos inaptos para a mecanização da colheita, de um total de 86.799 ha. Para que houvesse mecanização, a produção de cana deveria sofrer deslocamento para outras regiões. Este fenômeno já está acontecendo, de acordo com Veiga Filho (1998), que descreve a liberação de 15 mil hectares em quatro usinas de um mesmo

grupo econômico, localizadas na região de Piracicaba, e que adquiriu o controle acionário de outra usina, instalada em Jaú (SP), com solos de alta fertilidade natural e baixa declividade, sendo adequados à mecanização da colheita:

- são consideradas como áreas de colheita mecanizável os canaviais instalados em terras com declividade menor que $12 \%$;

- as áreas de colheita mecanizável, pertencentes a fornecedores e por eles colhidas, sem qualquer auxílio ou interferência de serviços prestados por quaisquer agroindústrias ou empresas a elas coligadas, ocupando área inferior a 125 ha, terão, para os efeitos deste regulamento, o mesmo tratamento que as áreas de colheita não mecanizável.

\subsubsection{Código Florestal}

Além das operações de colheita com queima prévia, para o planejamento agrícola em um ambiente de SIG, deve-se considerar outros aspectos do código florestal. De acordo com Machado (2002), a Lei $n{ }^{\circ} 4.771 / 65$ determina a proteção de florestas nativas e define as Áreas de Preservação Permanente (APP), onde a conservação da vegetação é obrigatória; uma faixa 
de 10 a 500 metros nas margens dos rios (dependendo da largura do curso d'água), na beira de lagos e de reservatórios de água, no topo de morros, encostas com declividade superior a $45^{\circ} \mathrm{e}$ locais acima de 1.800 metros de altitude. Também exige que as propriedades rurais da região Sudeste do País preservem $20 \%$ da cobertura arbórea, devendo tal reserva ser averbada no registro de imóveis, a partir do que fica proibido o desmatamento, mesmo que a área seja vendida ou repartida (Brasil, 1965).

\subsection{3 Áreas de Proteção Ambiental}

A análise do uso e ocupação do solo evidencia a pouca disponibilidade de áreas com matas remanescentes, denunciando um total descumprimento da legislação em vigor. Mais do que o simples cumprimento da legislação a não proteção dos mananciais com matas ciliares causa severos danos ao ambiente. De acordo com Crestana et al. (1993), deve-se considerar que as matas ciliares cumprem o seguinte papel:

- reduzem as perdas de solos decorrentes de processos erosivos e de solapamento das margens, causadas pela ausência de vegetação;

- aumentam os refúgios e fontes de alimentação para as faunas silvestre e aquática;

- asseguram a perenidade das fontes e nascentes;

- protegem os cursos d'água dos impactos decorrentes do transporte de defensivos, corretivos e fertilizantes;

- melhoram a qualidade e aumentam o volume de água para consumo humano e uso agrícola;

- promovem o repovoamento faunístico das matas artificiais e dos cursos d'água.

Para Crestana et al. (1993) a ausência de matas ciliares tem contribuído para o assoreamento dos leitos dos córregos, vindo a causar uma grande diminuição da oferta de água. A qualidade da água também pode ser afetada pela presença do elemento ferro nos corpos d'água, vindo a causar danos sérios ao bom funcionamento dos sistemas de irrigação.

Nesse sentido, torna-se imperioso e urgente à recomposição das matas ciliares, de modo a proteger os mananciais. Dessa maneira, segundo Crestana et al.(1993), deve-se proporcionar a recomposição da mata ciliar, considerando uma faixa de 30 metros de largura ao longo de todos os canais de drenagem, de acordo com a Lei em vigor, que regulamenta uma faixa de 30 metros. Nos casos das barragens, considerando o pequeno porte das propriedades 
rurais, a proposta é de se considerar também uma recomposição de uma faixa de 30 metros (SOUZA, 1995).

\subsubsection{Controle de erosão em estradas rurais e carreadores}

As estradas rurais são a infraestrutura que permitem o transporte e escoamento da produção agrícola aos centros de venda dos produtos. Elas são o meio de comunicação das comunidades e por meio dela se dão o carreamento das riquezas nacionais (Bertolini et al., 1982).

Segundo o DERSA (1975), o Estado de São Paulo conta com aproximadamente $200.000 \mathrm{~km}$ de estradas, sendo menos de 10\% pavimentada, o que resulta em cerca de $180.000 \mathrm{~km}$ de estradas estaduais e municipais de terra.

Considerando o alto custo da pavimentação, a busca por novas alternativas que mantenham as estradas em níveis aceitáveis de trafego e custo se torna indispensável.

Para agravar ainda mais a situação de degradação das estradas, as chuvas no Estado de São Paulo, que se concentram entre outubro e março, coincidem com a maior intensidade de tráfego, em virtude do transporte de insumos e produtos (DERSA, 1975).

Como as águas pluviais constituem a principal causa dos estragos ocasionados pela erosão nas estradas, a captação e controle dessas águas, são extremamente importantes, de modo que, se acumule-as em locais determinados, favorecendo sua penetração do solo, favorecendo o abastecimento do lençol freático e, conseqüentemente, alimentando fontes e nascentes naturais (Ross, 1994).

Os problemas oriundos ao manejo inadequado das águas pluviais, segundo Lima (1976), "causam danos consideráveis às estradas e áreas adjacentes, uma vez que estas áreas recebem o deflúvio superficial das estradas". Por outro lado, estas áreas cultivadas próximas às estradas às vezes são responsáveis pelo acúmulo de material em taludes e leitos carroçáveis.

Para Lima (1976), tanto as estradas regionais como os carreadores, devem ser planejados e construídos de modo a atingir vários propósitos como:

- $\quad$ ser transitável o maior tempo possível;

- servir os pontos escolhidos;

- permitir o escoamento da produção local;

- reduzir os custos de transporte e manutenção de veículos;

- prevenir danos ambientais pelo efeito erosivo. 
Além destes fatores, devemos considerar também o menor custo construtivo, a velocidade diretriz, os pontos de passagem obrigatórios (pontes, viadutos, etc.), a classe de solo da região e o relevo local (DERSA, 1975).

De acordo com Bertolini et al. (1982), a declividade das encostas é o principal fator do relevo condicionante da erosão. Sua variação determina formas e feições da paisagem, ditando também potencialidades de uso e restrição ao aproveitamento das terras. As classes, discretizadas de acordo com De Biasi (1991), são; de A (0-3\%), B (3-6\%), C (6-12\%), D (1220\%), E (maior que 20\%) e hidromórfico (<3\%):

- classe A (0-3\%): Compreende áreas planas ou quase planas, onde o escoamento superficial (deflúvio) é lento ou muito lento. Esta classe não oferece dificuldade ao uso de máquinas agrícolas. A erosão hídrica não é significativa, exceto em vertentes muito longas e com solos altamente suscetíveis à erosão;

- classe B (3-6\%): Os terrenos desta classe têm declives suaves, onde geralmente o deflúvio é lento ou médio. O trabalho mecanizado usual é de fácil operação. Geralmente práticas simples de conservação do solo são suficientes (cultivo em nível ou plantio direto), exceto em solos erodíveis (arenosos) com comprimento de rampa muito longo;

- classe C (6-12\%): Engloba terrenos inclinados, em relevo geralmente ondulado. O deflúvio é médio ou rápido. O declive normalmente não prejudica o uso de máquinas agrícolas. Em alguns casos a erosão hídrica pode ser controlada com práticas simples. Porém, normalmente são necessárias práticas complexas de conservação do solo (terraceamento, plantio direto, etc.), para que seja cultivado intensamente;

- classe D (12-20\%): Compreende terrenos inclinados em relevo ondulado. Geralmente o escoamento superficial é rápido para a grande maioria dos solos. O uso de máquinas agrícolas é parcialmente prejudicado. A erosão hídrica compromete o cultivo intenso;

- classe E (>20\%): Constitui terrenos muito inclinados a fortemente inclinados onde o escoamento superficial é muito rápido. A grande maioria dos solos é extremamente suscetível à erosão, e os terrenos devem ser utilizados somente para cultivos perenes, pastagens ou reflorestamentos. A maior parte das máquinas agrícolas pode ser usada, mas com dificuldades. Existem sérios impedimentos ao uso, exigindo práticas muito complexas (projetos de drenagem), e devem ser mantidos preferencialmente como áreas de preservação ambiental;

- hidromórfico (<3\%): As áreas com predomínio de solos hidromórficos representam áreas encharcadas planas ou quase planas (declividade menor que 3\%) e constituem unidade específica de capacidade de uso da terra. 


\subsection{Aspectos agronômicos}

Como a matéria-prima da indústria sucroalcooleira é produzida no campo e sua participação na formação dos custos de açúcar e do álcool é bastante elevada, ao redor de $60 \%$ (Veiga Filho, 1998), o progresso técnico nesta área tem um papel chave na competitividade setorial, seja pelo rebaixamento dos custos de produção do açúcar e do álcool, como por possibilitar a redução de preços dos subprodutos e co-produtos ao mercado comprador.

A necessidade de se adotar tecnologias que permitam incrementar o rendimento financeiro e, conseqüentemente, garantir a oferta dos produtos oriundos da cana-de-açúcar é imprescindível. Entre as tecnologias e conceitos que surgiram recentemente, estão os conceitos da Agricultura de Precisão, que é nada mais que um conjunto de técnicas que permite o levantamento de informações das culturas para facilitar o gerenciamento localizado. A implementação da Agricultura de Precisão permite a aplicação de um sistema de gerenciamento eficiente, como mapas de produtividade, georreferenciamento de talhões e acesso a dados qualitativos relacionados a dados geográficos (Molin, 2001).

\subsubsection{Clima e solo}

Segundo Prado (1996), a cana-de-açúcar é uma planta semiperene, que possui desenvolvimento radicular relacionado com as condições físico-hídricas, químicas e morfológicas da camada subsuperficial (0,8-1,0 m de profundidade, se não existir rocha).

Um dos fatores que mais interferem no crescimento radicular em profundidade é a

disponibilidade de água. Em condições de déficit hídrico, o crescimento radicular e conseqüentemente a produtividade podem reduzir-se significativamente até mesmo num solo rico abaixo da camada arável, se ocorrer forte limitação hídrica, quando existe a maior demanda por água (Prado,1996).

Um solo rico abaixo da camada arável (eutrófico) não representa o melhor ambiente de produção (A1) se for baixa a disponibilidade de água. Se o caráter eutrófico sozinho fosse responsável para se enquadrar no ambiente $A$, as regiões semi-áridas (Vertissolos) do Brasil representariam o melhor ambiente de produção. Além disso, esse solo pode salinizar-se ao longo do tempo, causando a morte da cana-de-açúcar, o que nos leva a classificá-lo no ambiente de produção E2, mesmo sendo o mais fértil dos solos brasileiros (Prado, 1996).

No Estado de São Paulo, por exemplo, um Latossolo eutrófico (rico) e com baixa disponibilidade de água enquadra-se no ambiente B1, mas se existir outra grave limitação, como, por exemplo, à baixa capacidade do solo reter cálcio, magnésio e potássio na camada 
arável (baixa capacidade de troca de cátions, ou baixa CTC), enquadra-se no ambiente C. Por outro lado, um solo muito pobre abaixo da camada arável (álico), com baixa disponibilidade de água e com baixa CTC na profundidade de 0-20 cm enquadra-se no ambiente $\mathrm{E}$, mas, se em outro local apresentar adequada disponibilidade de água e retenção de cálcio, magnésio e potássio na camada arável (alta CTC) são reclassificados no ambiente $\mathrm{D}$, ou até mesmo no C1 (Prado, 1996).

Para o mesmo autor, três fatores devem ser considerados na disponibilidade de água para a cana-de-açúcar: o solo, o clima e a planta. Existem solos que disponibilizam para a cultura 120 litros de água por metro cúbico, outros, mais limitantes, apenas 40 litros de água por metro cúbico. Se no clima local existe uma evapotranspiração de $5 \mathrm{~mm} / \mathrm{dia}$, após uma adequada chuva (ou irrigação) no volume de 1 metro cúbico, o primeiro solo fornecerá água por 24 dias consecutivos (120 dividido por 5), enquanto que o segundo solo disponibilizará água por apenas 8 dias consecutivos (40 dividido por 5), considerando que não chova pela segunda vez dentro desses respectivos 24 e 8 dias. Portanto, a partir do vigésimo quinto dia para o primeiro solo e do nono dia, para o segundo, a cana-de-açúcar não terá água disponível em nenhum ponto no volume de cada metro cúbico, a menos que chova novamente ou se faça irrigação (Prado, 1996).

Para Prado (1996), a adequação dos ambientes de produção deve considerar os seguintes fatores:

- conhecer a classe de solo;

- utilizar as informações para melhor manejo da cana-de-açúcar visando os maiores lucros sem degradar o ambiente.

\subsubsection{Geometria de talhões}

As operações agrícolas necessitam de deslocamento ordenado nas glebas, sobre toda a extensão da superfície do terreno. As máquinas se utilizam disso para o preparo, do solo, plantio, cultivo, de aplicação de defensivos e colheita. Segundo Mialhe (1974), as operações de preparo periódico de solo são as mais importantes em relação aos métodos de distribuição de percurso de campo.

Os campos de cultura apesar de possuírem formatos bem distintos, podem ser enquadrados, como exemplifica a Figura 1, nos seguintes modelos geométricos básicos; retângulo, quadrado, trapézio, triângulo e faixas sinuosas. Além do modelo geométrico, a declividade do terreno também contribui para o formato e tamanho dos talhões. Para Mialhe 
(1974), "o sentido de tráfego de máquinas, bem como o alinhamento das culturas em fileiras, será aquele em nível, segundo uma direção perpendicular à linha de declive máxima".

Faixa sinuosa

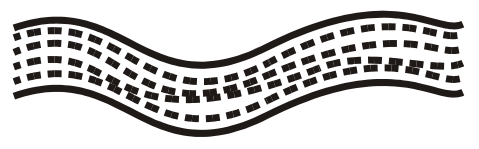

Quadrado
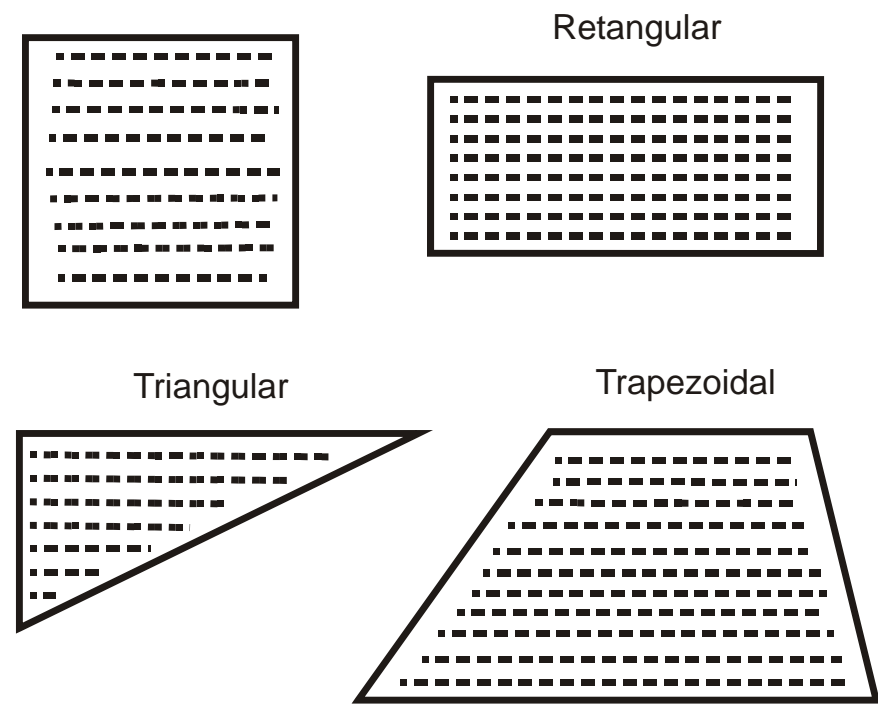

Figura 1 - Formato de talhões (adaptado de Mialhe, 1974)

Para Furlani Neto (1994) é necessário que se faça adaptações e alterações no que é rotulado de sistematização dos talhões que são:

- alterar o comprimento dos talhões, os quais tem, no sistema de colheita manual, comprimento de 200 a $300 \mathrm{~m}$ e que precisam ser modificados para $400 \mathrm{~m}$ ou mais para aumentar o desempenho das operações agrícolas, ocasionado pela redução das manobras de cabeceira e estabilização da velocidade média;

- alterar a forma de se fazer as linhas dos sulcos, que devem seguir paralelas às curvas de nível, evitando-se a presença dos "bicos", sulcos que vão diminuindo de tamanho e que implicam em aumento de manobras da colhedora e do veículo de carga sobre o talhão; 
- sistematizar os terrenos, que consiste em nivelar o terreno antes do plantio para evitar as micro-ondulações que impedem uma melhor evolução da velocidade média das operações agrícoals e prejudicam o corte basal correto dos colmos;

- diminuir o desnível entre o carreador e o talhão, para evitar que as linhas de cana próximas ao carreador tenham que ser cortadas manualmente.

Para Conde (1995), o tamanho ideal de talhões situa-se entre 10 a 20 ha, dependendo da classe do solo. O uso de máquinas no campo tem relação direta no aumento da compactação dos solos, prejudicial ao desenvolvimento da cana no plantio e nas rebrotas. Este problema é potencializado com o uso de colhedoras e caminhão de carga, devendo este conjunto ser redimensionado para evitar a entrada do veículo pesado, o qual pode ser substituído por tratores e carretas com pneus de alta flutuação, utilizados como veículos de transbordo.

A otimização dessas mudanças organizacionais depende do desenvolvimento de técnicas complementares, de alterações e ajustes ou de pequenos inventos que aumentem os desempenhos operacionais e reduzam os custos, colaborando para a difusão do processo de inovação. Este é o caso do arranjo dos componentes físicos (colhedora, caminhões e tratores, veículos de manutenção, etc.) envolvidos na operação da colheita mecanizada e sua operacionalidade, que demandam o desenvolvimento de métodos e de levantamentos das condições locais, além do estabelecimento de critérios para quantificar o número de veículos que racionalizem as operações mecanizadas (Rípoli \& Balastreire, 1976).

Nesta linha de técnicas complementares está a proposição de uma nova sistemática de plantio de cana (Furlani Neto, 1994) para melhorar o desempenho das colhedoras, chamado de sistema de sulcos alternados duplos. Nesse sistema altera-se o espaçamento tradicional de 1,40 m para 1,40 m x 0,80 m, originando duas linhas plantadas à distância de 0,80 m, seguidas de outras duas linhas plantadas a 0,80 m, distantes entre si por $1,40 \mathrm{~m}$, permitindo o corte simultâneo de duas linhas e reduzindo o tráfego no talhão em $36 \%$. O menor pisoteio pode contribuir para aumentar a longevidade e produtividade dos canaviais, assim como reduzir custos de operação. 


\subsubsection{Ciclos operativos de campo}

Para Mialhe (1974) ciclo operativo de campo é a nomenclatura dada ao percurso sucessivo que as máquinas executam no campo, segundo uma orientação. Para exemplificar, na Figura 2 é ilustrado o ciclo operacional, denominado ciclo unidirecional fechado, que é caracterizado por passadas nas regiões mais externas do talhão, e a cada volta, na mesma direção, a passada se aproxima do centro do talhão.

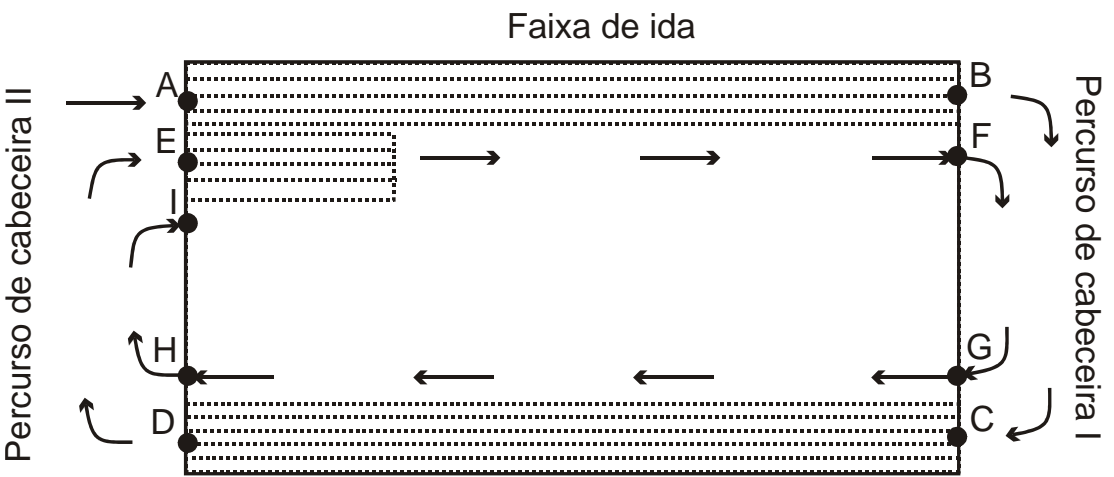

Faixa de volta

Figura 2 - Ciclo de operação de campo unidirecional para preparo de solo (adaptado de Mialhe, 1974)

Outro ciclo operacional conhecido é denominado ciclo operacional aberto, cujo sentido é indeterminado, como mostra a Figura 3.

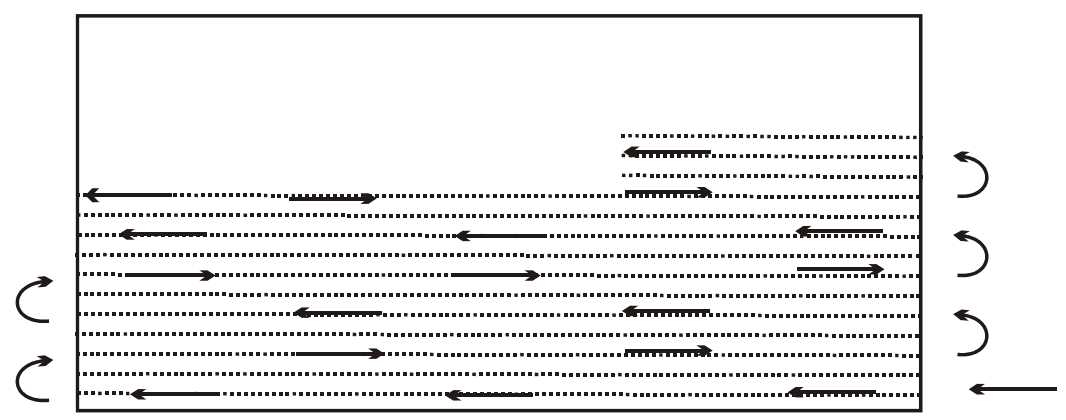

Figura 3 - Ciclo operacional aberto para preparo de solo (adaptado de Mialhe, 1974)

Para a análise de eficiência de percurso, é utilizada uma equação (Mialhe, 1974) na qual são considerados a largura e comprimento do talhão, a largura de trabalho do implemento 
agrícola e o número de passadas sobre o talhão. Na Figura 4, é ilustrado o esquema para a análise do ciclo operativo unidirecional fechado.

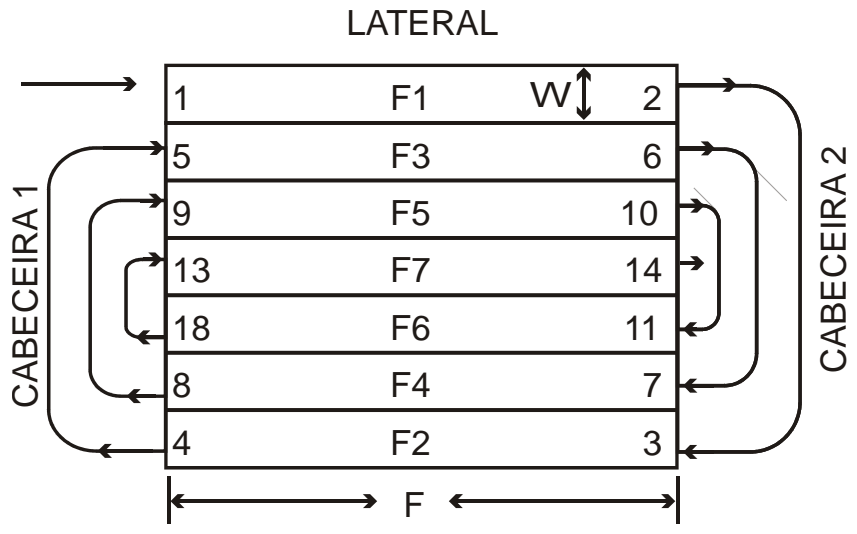

Figura 4 - Esquema para a análise do ciclo operativo unidirecional fechado, de sentido horário, para gradagem em faixas alternadas (adaptado de Mialhe, 1974)

Os símbolos utilizados na Figura 4 são:

$w=$ largura de trabalho da

$\mathbf{W}=$ largura do

$\mathbf{F}=$ comprimento de faixa de operação = comprimento

$\mathbf{n}=$ número de faixas ou

de onde resulta a eq.(1):

$E P \%=\frac{F}{F+\left(\frac{W-w}{2}\right)} 100$

Analisando a eq. (1) pode-se concluir que:

Quando $W=W$, ou seja, a largura de corte da máquina for, teoricamente igual à largura do talhão, a eficiência de percurso é máxima (EP=100\%). Portanto, o planejamento da base física dos talhões deve seguir os seguintes critérios (Mialhe, 1974): 
- utilizar máquinas com grande largura de corte ou talhões cujas larguras sejam relativamente pequenas;

- estabelecer geometrias para os talhões que resulte, para uma mesma área, F relativamente bem maior que $\mathrm{W}$.

\subsection{Sensoriamento remoto}

Segundo INPE (2003), sensoriamento remoto pode ser definido como: "É a utilização de sensores para aquisição de informações sobre objetos ou fenômenos sem que haja contato direto entre eles".

Fotografias aéreas assim como imagens orbitais são, portanto, dados de Sensoriamento Remoto. As informações são obtidas através radiação refletida ou emitida por sua superfície, ao longo do espectro eletromagnético, através de sensores de campo, instalados em aeronaves ou satélites (Mather, 1987).

Kennie \& Matthews (1985) atribuíam o enriquecimento de detalhes em uma imagem orbital pela utilização de fotografias aéreas.

\subsubsection{Tipos de sensores}

De acordo com INPE (2002), os sensores podem ser classificados em função da fonte de energia:

- Passivos: não possui uma fonte própria de radiação. Ele mede radiação solar refletida ou radiação emitida pelos alvos. ex: sistemas fotográficos;

- Ativos: possui sua própria fonte de radiação eletromagnética, trabalhando em faixas restritas do espectro. ex: radares.

Ou em função do tipo de produto:

- Não-imageadores: não fornecem uma imagem da superfície sensoriada. ex: radiômetros (saída em dígitos ou gráficos) e espectrorradiômetros (assinatura espectral). São essenciais para a aquisição de informações minuciosas sobre o comportamento espectral dos objetos da superfície terrestre. 
- Imageadores: obtem-se como resultado uma imagem da superfície observada. Fornecem informações sobre a variação espacial da resposta espectral da superfície observada.

o sistema de quadro ("framing systems"): adquirem a imagem da cena em sua totalidade num mesmo instante. (ex: RBV);

o sistema de varredura ("scanning systems") ex: TM, MSS, SPOT, etc.;

o sistema fotográfico.

\subsubsection{Resolução de uma imagem}

Segundo INPE (2002) resolução é uma medida da habilidade que um sistema sensor possui de distinguir entre respostas que são semelhantes espectralmente ou próximas espacialmente. A resolução pode ser classificada em espacial, espectral, radiométrica e temporal.

- resolução espacial: mede a menor separação angular ou linear entre dois objetos. Por exemplo, uma resolução de 20 metros implica que objetos distanciados entre si a menos que 20 metros, em geral não serão discriminados na imagem;

- resolução espectral: é uma medida da largura das faixas espectrais do sistema sensor. Por exemplo, um sensor que opera na faixa de 0,4 a 0,45 $\mathrm{m}$ tem uma resolução espectral menor do que o sensor que opera na faixa de 0,4 a 0,5 um;

- resolução radiométrica: está associada à sensibilidade do sistema sensor em distinguir dois níveis de intensidade do sinal de retorno. Por exemplo, uma resolução de 10 bits (1024 níveis digitais) é melhor que uma de 8 bits;

- resolução temporal: corresponde ao tempo, expresso em dias necessários para que ocorra uma revisita a uma determinada área. É utilizada para monitorar mudanças no ambiente. 


\subsubsection{Fotogrametria}

Wolf (1983) definiu fotogrametria como "a arte, ciência e tecnologia de se obter informações confiáveis sobre objetos físicos e o meio ambiente através do processo de registrar, medir e interpretar fotografias e outros padrões de energia eletromagnética radiante registrada".

Existem duas áreas distintas dentro da fotogrametria: a métrica ou simplesmente fotogrametria e a interpretativa ou fotointerpretação. Fotogrametria consiste em tomar medidas precisas a partir de fotografias e de outras Fontes de informação para determinar a posição relativa de pontos. Isso possibilita calcular distâncias, ângulos, áreas, volumes, alturas, tamanhos e formas de objetos. Nessa atividade, as fotografias são mais freqüentemente aéreas, ou seja, tomadas a partir de avião, mas fotografias terrestres também são usadas (Wolf, 1974).

A aplicação mais comum de aerofotos ocorre em trabalhos de mapeamento. Em extensas áreas, mapas planialtimétricos podem ser feitos, a partir de tais fotografias, com grande precisão e de forma mais rápida e econômica que os levantamentos com instrumentais de campo (Wolf, 1974).

As fotografias aéreas, tais como são, não podem ser consideradas como mapas, mas, por métodos fotogramétricos e com uso de geometria sólida e plana, pode-se fazer mapas planialtimétricos a partir de fotografias (Marchetti \& Garcia, 1986).

\subsection{Sistema de Posicionamento Global}

O desenvolvimento do GPS (Global Positioning System), foi projetado pelo Departamento de Defesa dos Estados Unidos da América (EUA) para oferecer a posição instantânea, bem como a velocidade e o horário de um ponto qualquer sobre a superfície terrestre ou bem próxima a ela num referencial tridimensional (Letham, 1996).

O sistema GPS entrou em operação em 1981 e em 1993 a constelação dos satélites utilizados pelo sistema foi concluída. Este sistema foi projetado de forma que em qualquer lugar do mundo e a qualquer momento existam pelo menos quatro satélites acima do plano horizontal do observador (Blitzkow, 1995).

Os satélites que compõem o segmento espacial do sistema GPS orbitam ao redor da Terra distribuídos em seis órbitas distintas, a uma altitude de $20.200 \mathrm{Km}$, distribuídos em seis planos orbitais com uma inclinação de $55^{\circ}$ em relação ao equador, e com um período de revolução de 12 horas siderais (Han et al., 1995). 
Essa configuração garante que, no mínimo, quatro satélites GPS sejam visíveis em qualquer local da superfície terrestre ou acima dela, a qualquer hora do dia (Monico, 2000).

\subsubsection{Método Diferencial de Posicionamento (DGPS)}

Neste método se a localização de um receptor for conhecida, podem-se comparar as coordenadas medidas com os valores conhecidos previamente e deste modo calcular correções às medições, as quais podem ser usadas para também corrigir as medições dos outros receptores que estão em pontos desconhecidos e não muito longes daquele local. O receptor na posição conhecida é chamado receptor base ou de referência, o receptor ou receptores que estão em posições desconhecidas são chamados "rover" (Bernardi \& Landim., 2002). O rastreador de referência calcula a distância do receptor a cada satélite, e baseando-se, na localização instantânea de cada satélite que é informada pelo sistema ao receptor e com as medidas de distâncias calculadas, um software incorporado no equipamento determina a posição do ponto (coordenadas) do receptor base. Em seguida, compara os valores calculados com os valores das coordenadas previamente conhecidas do local. A diferença entre esses valores indica o erro cometido pelo sistema no ponto base (Bernardi \& Landim., 2002). Como grande parte dos erros que afetam o GPS são oriundos de fenômenos físicos da ionosfera e da troposfera e estes efeitos são relativamente constantes num raio de algumas dezenas de quilômetros ao redor do ponto base pode-se supor que os pontos "rover" se não estão muito distantes da base sofrerão os mesmos efeitos e conseqüentemente apresentarão o mesmo erro da base. Este valor é fornecido ao "rover" em tempo real ou em tempo diferido e o mesmo pode então calcular a sua posição com maior exatidão (Bernardi \& Landim., 2002). O DGPS é baseado na medição da distância receptor-satélite através da observação do código. Se não ha necessidade de trabalhar em tempo real as medições da base e do "rover" são gravadas e mais tarde transferidas para um computador para serem efetuados os cálculos. Esta técnica é usualmente designada por DGPS em pós-processamento (Bernardi \& Landim., 2002). 


\subsubsection{GPS e banco de dados espaciais}

Para (Bernardi \& Landim., 2002). o GPS é um sistema multipropósitos, que permite ao usuário determinar suas posições expressa em latitude, longitude, altura geométrica ou elipsoidal, velocidade e o tempo em relação a um sistema de referência definido para qualquer ponto sobre ou próximo da superfície da Terra. Com a criação e aperfeiçoamento do GPS nas ultimas décadas houve um avanço tecnológico significativo nas áreas de geodésia e cartografia

Entretanto, com a crescente utilização do GPS nos levantamentos geodésicos, geológicos, cartográficos e ambientais induz à necessidade de adoção de sistemas de referências geocêntricos. Para a determinação de uma posição qualquer no espaço ou na Terra, o sistema operacional GPS utiliza como referência o sistema geodésico denominado de World Geodetic System (WGS84) de 1984. Dentro deste contexto deve-se ter uma série de cuidados com as transformações de datum, escala e tipos de projeções (Bernardi \& Landim., 2002).

\subsection{Sistema de Informações Geográficas}

Os Sistemas de Informações Geográficas (SIG's) surgiram há mais de três décadas e tem-se tornado uma ferramenta valiosa nas mais diversas áreas de conhecimento. Tais sistemas constituem um ambiente tecnológico e organizacional que tem, cada vez mais, ganho adeptos no mundo todo. Entre o final da década passada e o início da atual houve um crescimento acentuado das aplicações de SIG's, o que se deve, em parte, ao advento e à disseminação do microcomputador pessoal, além da introdução de tecnologia de relativo baixo custo e alta capacidade de performance, tais como as estações de trabalho (Assad, 1993).

Segundo Assad (1993), "Sistema de Informações Geográficas (SIG) é uma ferramenta computacional que permite cruzar vários tipos de informações, facilitando a tomada de decisão, considerando os fatores pertinentes ao empreendimento". As técnicas de SIG fornecem meios para o levantamento atualizado de recursos físicos (topografia, solos, minérios, água e biota), que tem grande influência em projetos de grandes áreas, considerando uma microbacia hidrográfica.

Tecnicamente, um SIG pode ser definido, segundo Aronoff (1989), como "um conjunto integrado de hardware e software para a aquisição, armazenamento, estruturação, manipulação, análise e exibição gráfica de dados espacialmente referenciados pelas coordenadas geográficas". Esta definição técnica reflete com exatidão os componentes físicos 
do SIG e as funções principais que tais sistemas executam, mas peca por não incluir o papel que as pessoas representam no sistema.

Entretanto, pessoas administram e usam SIG. Pela ótica dos planejadores urbanos e rurais, cientistas ambientais e muitos outros usuários de SIG, tais sistemas são ferramentas para realizar o inventário de dados geográficos, fundir dados de muitas fontes, monitorar e avaliar a condição de nosso ambiente e modelar ou predizer as conseqüências das alterações humanas no ambiente. São necessários ambos os pontos de vista para definir por completo o que um SIG é e entender o crescimento fenomenal do uso de SIG durante a última década.

\subsubsection{SIG aplicado ao planejamento rural}

De acordo com Câmara (1995), os SIG's podem ser utilizados da seguinte maneira:

- para compor e gerenciar uma base de dados geográficos, composta de informações provenientes de diversas Fontes (mapas, dados de censo, cadastro urbano e rural, imagens de satélite, GPS);

- subsidiar a análise espacial de fenômenos, pela consulta, recuperação, visualização e combinação de variáveis que descrevem o ambiente geográfico;

- para a produzir cartografia, pelo registro de dados geográficos, que podem ser acessados de forma rápida e simplificada.

Um SIG é uma representação do mundo real, e para a sua adequada representação, os dados coletados devem ser minuciosamente elaborados, buscando entender o fenômeno estudado, simplificando a realidade, correlacionando fatores e por fim facilitando a tomada de decisão (Câmara, 1995).

Para Aronoff (1989) as atividades intrínsecas de um SIG, iniciam e terminam no mundo real (Figura 5). O mesmo autor considera o sucesso de um SIG depende de quatro fatores:

- o conjunto de dados utilizado em SIG consiste necessariamente de abstrações da realidade, sobre as quais se desenvolve o raciocínio de planejamento, devendo ser coletadas apenas informações relevantes ao projeto;

- a organização da base de dados constitui um sistema simples que permite a entrada, a armazenagem e a recuperação dos dados; 
- o modelo conceitual consiste em abstrações, generalizações e aproximações que representam um objeto ou fenômeno que existe no mundo real. Um bom modelo é aquele que prediz o comportamento do mundo real para o fenômeno de interesse, de forma correta e consistente, ajustando-se aos resultados da realidade;

- o critério de análise importa não apenas para a tomada de decisão referente à seleção da melhor dentre as opções de ação sob aspectos específicos, mas também para o conhecimento das conseqüências decorrentes da opção feita, bem como, da determinação de ações preventivas que potencializem as conseqüências positivas e minimizem as negativas.

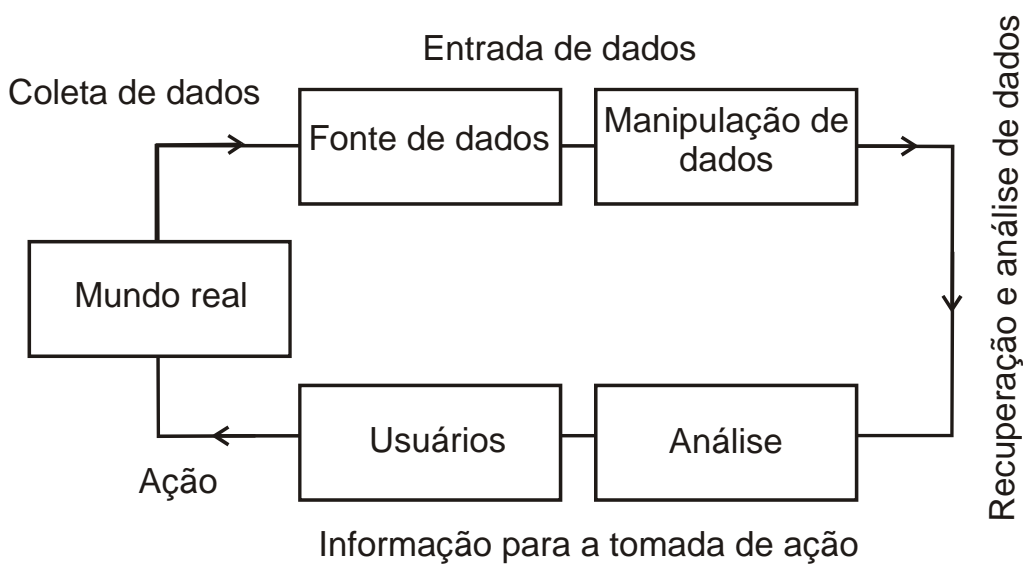

Figura 5 - Esquema de um SIG aplicado em um processo de planejamento. (Adaptado de Aronoff , 1989)

\subsubsection{Banco de dados geográficos}

Uma vez que os dados para análises do SIG foram adquiridos de várias fontes, uma base de dados geometricamente consistentes e topologicamente estruturados deve ser criada para o conjunto de dados. Obter um conjunto de dados cartográficos geometricamente consistentes, sempre foi primordial na compilação de mapas, desde que todos os materiais devam ser trazidos à mesma escala e projeção cartográfica ou sistema de coordenadas. De acordo com Courseware (2000) o mapeamento digital matricial em um SIG vem a exigência adicional que todos os pixels sejam do mesmo tamanho e forma e registrados exatamente com os outros dados raster. 


\subsubsection{Objetos cartográficos}

Objetos cartográficos são os componentes geométricos básicos da cartografia e dos bancos de dados do SIG que definem três entidades geométricas fundamentais (INPE, 2003); pontos, linhas e poligonos. Estas entidades são usadas para representar as características ambientais. O formato de representação pode ser matricial ou vetorial (Figura 6).

\subsubsection{Objetos vetoriais}

- ponto: um objeto adimensional especificando a localização geográfica por um conjunto de coordenadas;

- nó: um objeto adimensional servindo como junção topológica a uma linha ou como ponto extremo (inicial ou final);

- segmento linear: uma linha reta entre dois pontos;

- seqüência linear: uma seqüência de segmentos lineares sem nós;

- cadeia: uma seqüência de segmentos lineares com nó inicial e nó final;

- anel: uma seqüência de cadeias ou seqüências lineares que formam uma poligonal fechada;

- polígono: um anel e sua área interna.

\subsubsection{Objetos matriciais}

- elemento matricial (pixel): um elemento bidimensional que é a menor parte não divisível em uma imagem;

- célula do quadriculado: um objeto bidimensional representado num elemento de uma tesselação regular da superfície. 


\section{Objetos Vetoriais}
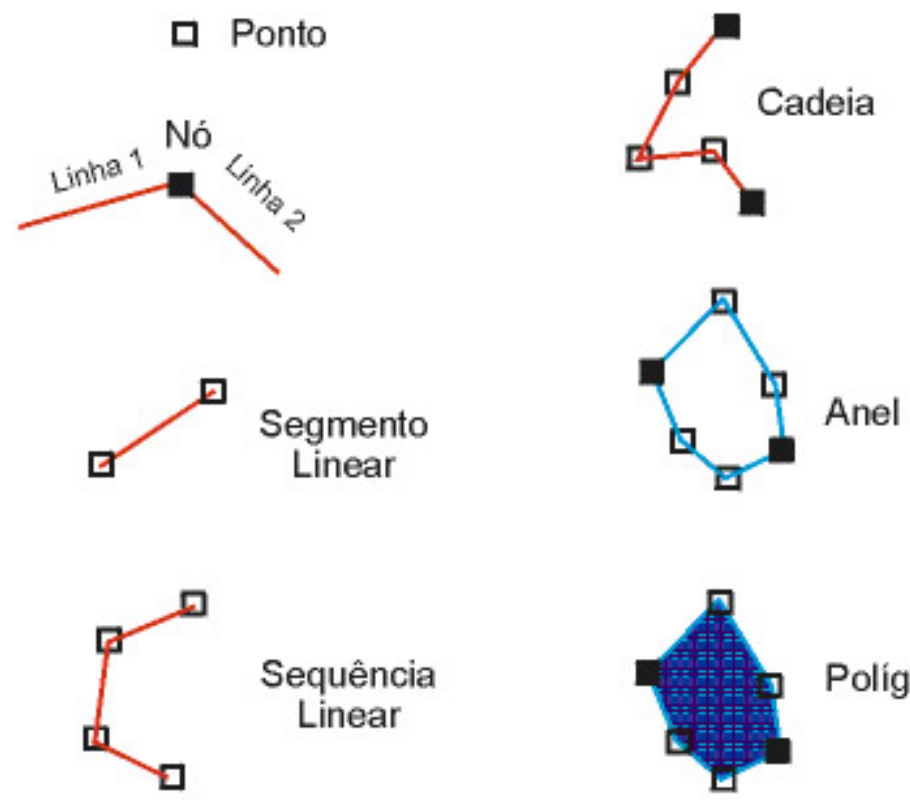

\section{Objetos Matriciais}

\section{Pixel}

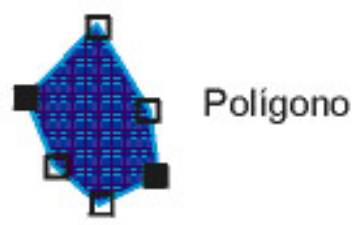

Figura 6 - Objetos topológicos.

Fonte: (INPE, 2003)

\subsection{4 Álgebra de mapas}

O termo "álgebra de mapas" foi cunhado por Tomlin (1990), para indicar o conjunto de procedimentos de análise espacial em Geoprocessamento que produz novos dados, a partir e funções de manipulação aplicadas a um ou mais mapas. Para Maguire (1991) e Shepherd (1991), as informações são reunidas em um SIG para que se possa:

- determinar quais tipos de feições ocorrem num dado local;

- $\quad$ procurar feições que possuam determinadas características;

- monitorar funções que variam com o tempo. 
Esta visão concebe a análise espacial como um conjunto de operações matemáticas sobre mapas, em analogia aos ambientes de álgebra e estatística tradicional. Os mapas são tratados como variáveis individuais, e as funções definidas sobre estas variáveis são aplicadas de forma homogênea a todos os pontos do mapa (Maguire, 1991).

A Álgebra de Mapas compõe uma linguagem especializada para realizar operações que tem tanto um sentido matemático quanto cartográfico e espacial. Estas operações podem ser agrupadas em três grandes classes (Maguire, 1991):

- pontuais: a saída da operação é um mapas cujos valores são função apenas dos valores dos mapa de entrada em cada localização correspondente. Podem operar apenas sobre um mapa (Fatiar um modelo numérico de terreno) ou realizar intersecções entre conjuntos espaciais (Operações booleanas entre mapas temáticos);

- vizinhança: o resultado é um mapa cujos valores dependem da vizinhança da localização considerada. Exemplos são a filtragem espacial de uma imagem e o cálculo de declividade de um MNT;

- zonais: definidas sobre regiões específicas de um mapa de entrada, onde as restrições são fornecidas por outro mapa. Um exemplo seria: "Dado um mapa de solos e um mapa de declividade da mesma região, obtenha a declividade média para cada tipo de solo".

As operações de transformações zonais ou por região operam sobre um mapa de origem e um conjunto de regiões delimitadas por polígonos na forma matricial ou vetorial. Diferentemente das transformações de vizinhança, onde cada posição geográfica possui sua própria vizinhança representada por uma máscara que se desloca sobre os dados, nas transformações zonais as regiões são estáticas, ou seja, não se deslocam sobre a região geográfica de estudo (Tomlin, 1990). As operações zonais mais comuns são:

- máximo e mínimo zonal: gera um mapa onde o valor resultante em todas as posições geográficas que compõem uma região é igual ao maior valor ou ao menor valor do atributo encontrado na mesma região sobre o mapa de origem;

- maioria zonal: o resultado e o valor em todas as posição geográficas dentro de uma região é igual ao valor de maior freqüência encontrado na mesma região sobre o mapa de origem (Figura 7);

- média zonal: o valor produzido, em todas as localizações que compõem uma região, é igual à média aritmética dos valores da variável geográfica nas mesmas localizações no mapa de origem; 
- diversidade zonal: gera um resultado onde o valor resultante em todas as posições geográficas que compõem uma região é igual ao número de valores diferentes do atributo no mapa de origem;

- estatística zonal: produz uma estatística dos valores para cada região. O resultado é um dado tabular indicando para cada região, os valores máximo, médio, mínimo, variância, desvio padrão e diversidade.

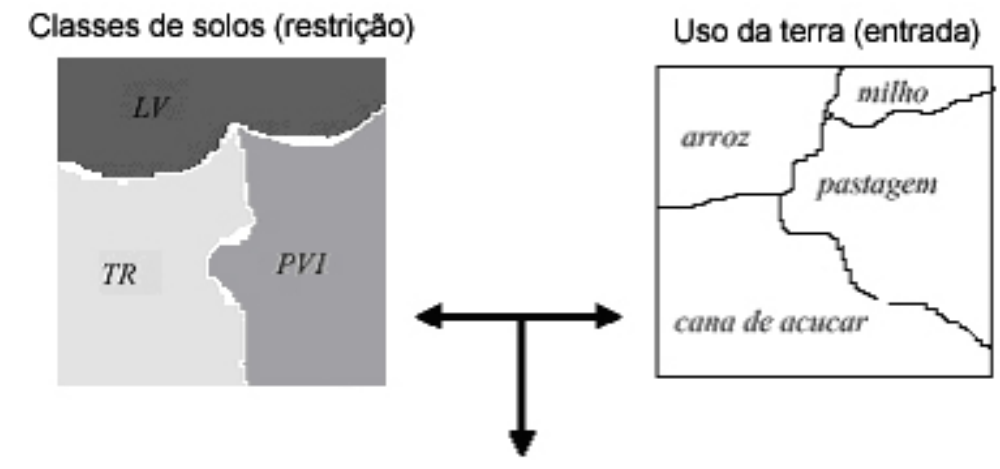

Cultura mais frequente em cada classe de solo (regiåo)

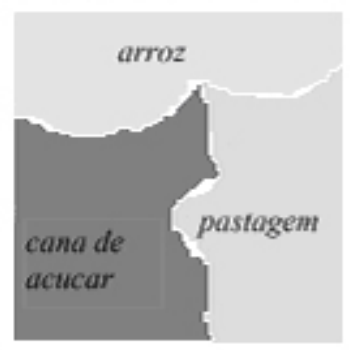

Figura 7 - Operação de maioria zonal.

Fonte: Barbosa (1997)

\subsubsection{Operações zonais em LEGAL}

O sistema SPRING (Câmara et al., 1996) inclui uma linguagem, de manipulação de dados, denominada LEGAL (Linguagem Espacial de Geoprocessamento Algébrico), que vem sendo implementada a partir de proposta original definida em Câmara (1995). As operações zonais em LEGAL possuem uma interface direta com tabelas de um bancos de dados relacional. Deste modo, o resultado de uma operação zonal pode ser diretamente armazenado como um atributo de elementos do banco de dados. Um exemplo de um programa em LEGAL, desenvolvido por Matteo (1998), para determinar o relacionamento entre o valor do índice de vegetação normalizado ("NDVI"), obtido das bandas TM4 e TM3 de uma imagem LANDSAT, 
com a produtividade de talhões de uma fazenda de cana de açúcar pode ser visualizado na Figura 8. A imagem estava no formato matricial e os talhões estavam associados a um mapa cadastral, com atributos armazenados num banco de dados relacional.

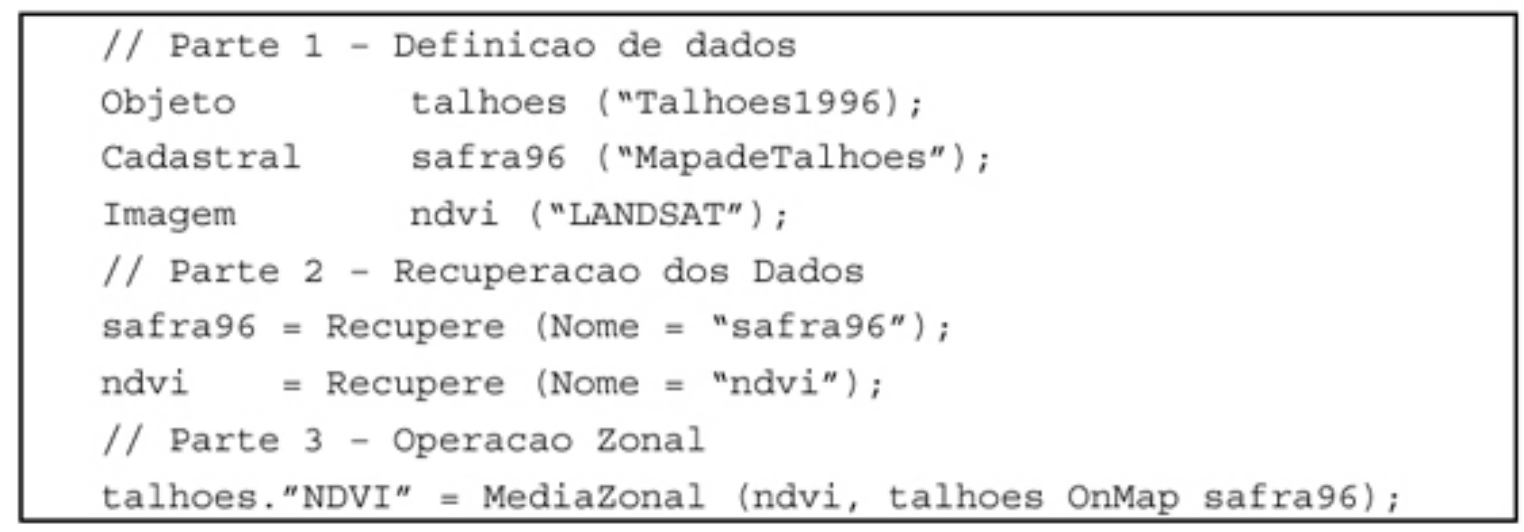

Figura 8 - Programa em LEGAL que integra dados matriciais e atributos de bancos de dados. Fonte: (Matteo, 1998)

A última linha do programa realiza, de uma só vez, todo o procedimento desejado. O campo "NDVI", correspondente a um atributo de cada talhão, será preenchido com os valores médios do índice de vegetação, calculados sobrepondo-se na imagem de satélite, os limites da cada talhão. Segundo Matteo (1998), não são conhecidas linguagens de álgebra de mapas que executam procedimentos que combinem mapas, bancos de dados e operadores zonais com semelhante grau de concisão. 


\subsubsection{Operações algébricas pontuais}

As operações no SIG SPRING são consideradas pontuais (Figura 9) porque são realizadas isoladamente para cada célula das matrizes de entrada (Penido, 1998), podendo ser da categoria temática, numérica ou imagens.

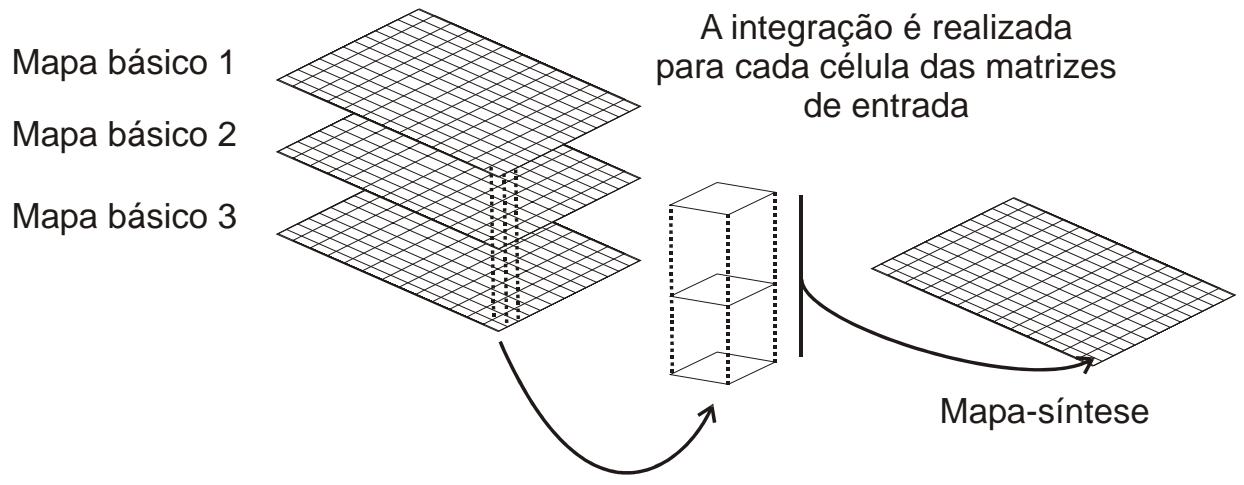

Figura 9 - Integração de planos de informação através de operação algébrica pontual (Adaptado de Aronoff , 1989)

Para Penido (1998), as principais operações algébricas pontuais para o planejamento urbano e rural são: combinação booleana, ponderação, multiplicação, fatiamento e reclassificação.

- combinação booleana: é realizada sobre os dados temáticos e gera um mapa-síntese onde o valor em cada posição geográfica é o resultado da aplicação de um operador da lógica booleana (AND, OR, NOT, XOR) sobre os valores dos atributos da mesma posição dos mapas básicos (mapas temáticos de entrada);

- ponderação: transforma dados temáticos em numéricos (grade regular) e produz uma grade regular onde o valor resultante em cada posição geográfica é a multiplicação dos valores de entrada;

- fatiamento: transforma um dado numérico em temático, pela substituição de intervalos de valores por atributos temáticos, segundo regras determinadas pelo usuário;

- reclassificação: agrega classes temáticas distintas, segundo com os padrões estabelecidos pelo tomador de decisão. 


\subsection{Processamento digital de imagens}

Por Processamento Digital de Imagens entende-se a "manipulação de uma imagem por computador de modo que a entrada e a saída do processo sejam imagens" (INPE, 2002). O objetivo de se usar processamento digital de imagens, é melhorar o aspecto visual de certas feições estruturais para o analista humano e fornecer outros subsídios para a sua interpretação, inclusive gerando produtos que possam ser posteriormente submetidos a outros processamentos.

Venturieri (1996) elencou as seguintes operações computacionais para a extração de informações de imagens orbitais ou aerofotos; pré-processamento, realce, segmentação e classificação.

- pré-processamento: Para imagens orbitais, é necessário fazer uma correção atmosférica, para corrigir as distorções de forma e cor causadas pela atmosfera. Os erros podem ser radiométricos ou geométricos (Mather, 1987) e Richard (1986). Em imagens provenientes de fotografias aéreas a correção geométrica tem como objetivo minimizar as distorções geométricas provenientes do sensor utilizado e da variabilidade da captação da imagem. Estas deformações são decorrentes da variação de altitude de vôo daplataforma do sensor, efeito de curvatura da terra, refração atmosférica e deslocamento em relação ao relevo (Novo, 1995);

- georreferenciamento: consiste em identificar pontos da imagem com coordenadas específicas, o usuário do SIG pode executar a operação de três maneiras: Por pontos de controle, obtidos através de DGPS; por uma mesa digitalizadora; ou por tela, na qual o usuário seleciona pontos de controle a partir de uma imagem já georreferenciada;

- realce de imagem: o objetivo desta técnica é melhorar a qualidade das imagens sob os critérios subjetivos do olho humano. O contraste entre dois objetos pode ser definido como a razão entre os seus níveis de cinza médios (INPE, 2002). A manipulação do contraste consiste numa transferência radiométrica em cada "pixel", com o objetivo de aumentar a discriminação visual entre os objetos presentes na imagem;

- segmentação da imagem: neste processo, a imagem é dividida em regiões que devem corresponder às áreas de interesse da aplicação. Entende-se por regiões, um conjunto de "pixels" contíguos, que se espalham bidirecionalmente e que apresentam uniformidade (Venturieri, 1996). A divisão em porções consiste basicamente em um processo de crescimento de regiões, de detecção de bordas ou de detecção de bacias; 
- classificação de imagens: processo de extração de informação em imagens para reconhecer padrões e objetos homogêneos. Os métodos de classificação são usados para mapear áreas da superfície terrestre que apresentam um mesmo significado em imagens digitais. Ela pode ser supervisionada, por regiões, a partir de uma imagem segmentada ou pós-classificada. Todas elas usam algoritmos computacionais baseados em modelos estatísticos. O conjunto de características espectrais de um "pixel" é denotado pelo termo "atributos espectrais" (INPE, 2002). 


\section{MATERIAL E MÉTODOS}

\subsection{Material}

\subsubsection{Caracterização da área de estudo}

A microbacia do Ribeirão dos Marins está localizada inteiramente no Município de Piracicaba, no centro-oeste do Estado de São Paulo (Figura 10). Esta área do Estado de São Paulo caracteriza-se por uma ocupação heterogênea do solo, com a maior parte da população concentrada em centros urbanos. As atividades econômicas são diversificadas, com áreas dominadas pela agropecuária, (cana-de-açúcar, hortaliças e a criação de gado de corte, leite, caprinos, ovinos e eqüinos) e outras por indústrias. Assim, a microbacia do Ribeirão dos Marins pode ser considerada como típica, em relação ao padrão de uso e ocupação do solo da região (Martinelli et al., 2002).

O clima da região é do tipo subtropical com temperaturas médias anuais entre 18 e $22^{\circ} \mathrm{C}$ (Sentelhas et al., 1999). A precipitação anual média é de aproximadamente $1300 \mathrm{~mm}$. Cerca de $70 \%$ do volume de precipitação ocorre no verão, situação característica de clima tropical. Em termos geomorfológicos, a bacia está localizada em terrenos sedimentares que formam a depressão periférica. A altitude média é de 529 metros, variando entre 465 e 615 metros. Como conseqüência, a bacia do ribeirão dos Marins apresenta uma rede de drenagem de $188 \mathrm{~km}$ de cursos de água permanentes, distribuídos em uma área de $58,7 \mathrm{~km}^{2}$, o que resulta em uma densidade de drenagem de 3,2 (Martinelli et al., 2002). O mesmo autor subdividiu a microbacia em 7 sub-bacias e destas, a sub-bacia 1 apresentou a maior porcentagem de área com o cultivo de cana-de-açúcar, sendo escolhida então para a elaboração deste estudo. 


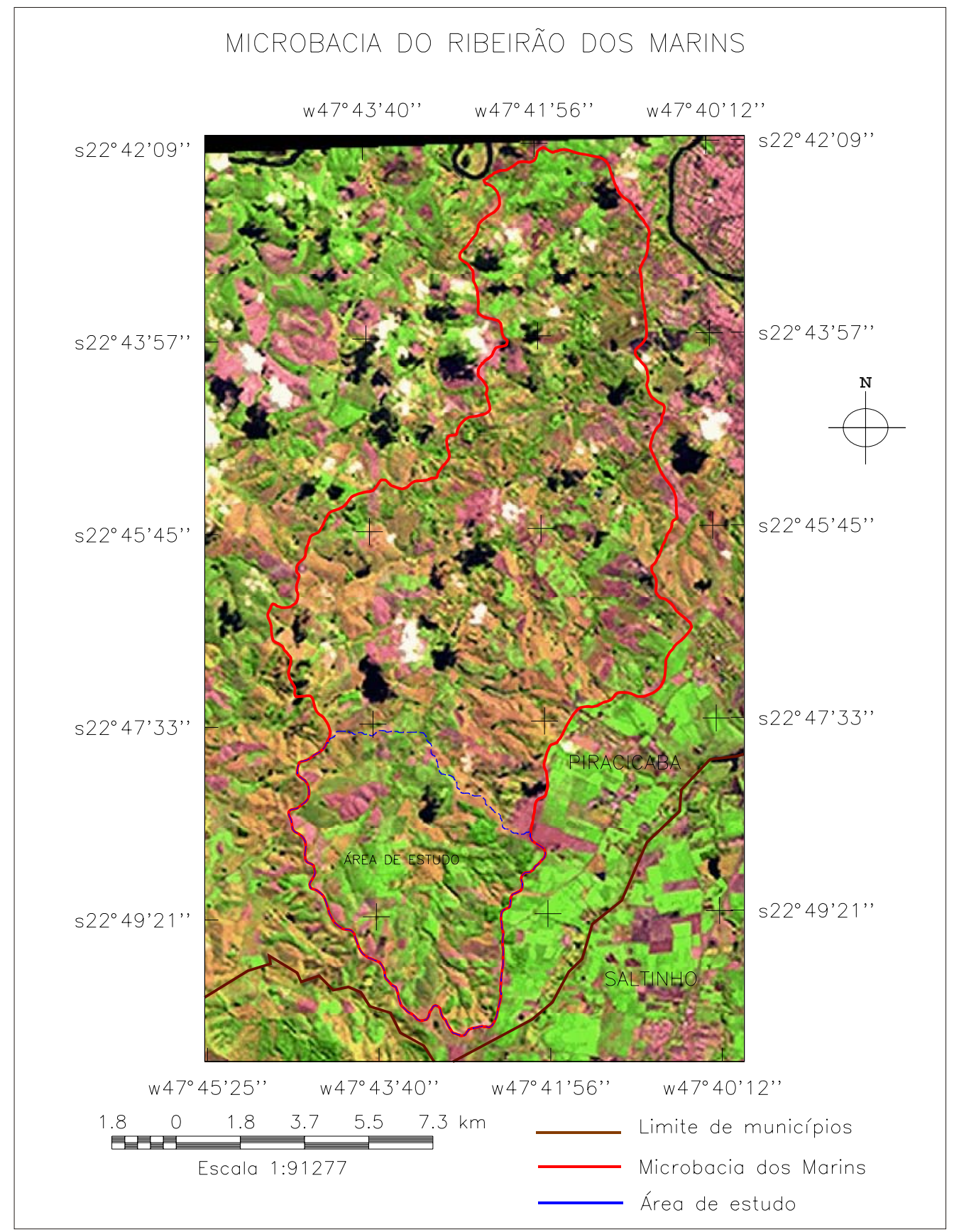

Figura 10 - Localização da área de estudo Fonte: EMBRAPA (2003) 


\subsubsection{Equipamentos e programas computacionais}

- Software SPRING 4.01 com sistema operacional Windows, com processador de 2,7 $\mathrm{MHz}$ e 512 de Memória RAM;

- DGPS de 12 canais;

- PalmTop com o software FieldRover®;

- Software GPS Track Maker® para descarregamento dos dados e software EXCEL® para elaboração de planilhas.

\subsubsection{Sistema de coordenadas e projeção}

Os planos de informação foram georrefenciados e projetados no sistema Universal Transverso de Mercator (UTM), zona 23, datum horizontal Córrego Alegre, esferóide Internacional, origem Equador, $45^{\circ} \mathrm{W}(10.000 \mathrm{~km} / 500 \mathrm{~km})$. Este sistema é do tipo cilíndrico conforme, permitindo representar corretamente áreas e distâncias.

\subsubsection{Categorias e planos de informação}

Foram utilizados mapas base de diversas Fontes para a elaboração do SIG, tais como: Cartas do IBGE, fotografias aéreas, pontos georreferenciados com DGPS, ensaios de campo, mapas pedológicos entre outros.

\subsubsection{Base cartográfica}

A base cartográfica deste banco de dados foi constituída pelas cartas base do Instituto Geográfico e Cartográfico do Estado de São Paulo na escala 1:10.000. Para cobrir a área de estudo foi utilizada a quadrícula: Piracicaba I (SF-23-Y-A-IV-2-S0-E). Deste mapa, foram extraídos os temas referentes à:

- topografia: linhas cotadas eqüidistantes 5 metros;

- rede de drenagem: rios, córregos, lagos e represas. 


\subsubsection{Pedologia}

O mapa de solos utilizado como base desse estudo (Projeto Radambrasil, SF. 23/24, 1983) foi produzido originalmente na escala de 1:250.000 (e formado mosaico em 1:1.000.000), - que determina que as Unidades de Mapeamentos dos Solos sejam compostas invariavelmente por associações de solos, dificultando a análise das características intrínsecas a cada tipo de solo, que determinam sua suscetibilidade à erosão. A utilização de técnicas de sensoriamento remoto, através de análise de fotografias aéreas é de extrema importância para a caracterização ser o mais próximo da realidade (Demattê, 1998). O mapa resultante é apresentado na Figura 11. A conversão para a nova nomenclatura foi realizada pelo autor segundo EMBRAPA (1999). A área de cada classe de solos é apresentada na Tabela 1 e descrição detalhada de cada unidade é a seguinte:

- PV_7 - Grupamento indiscriminado de ARGISSOLOS VERMELHO_AMARELOS abruptos, A moderado e espesso, textura arenosa/média. Unidade Serrinha (Arenic Abruptic Paleudalt).

- PV_8 - Grupamento indiscriminado de ARGISSOLOS VERMELHO_AMARELOS abruptos, A moderado e espesso, textura arenosa/média pouco profundos. Unidade Serrinha fase pouco profunda. (Arenic Abruptic Paleudalf).

- PV_9 - Grupamento indiscriminado de ARGISSOLOS VERMELHO_AMARELOS Tb abruptos, A moderado, textura arenosa/argilosa ou média/argilosa. Unidade Santa Cruz. (Abruptic Paleudalf e Abruptic Arenic Paleudalf).

- PV_10 - Grupamento indiscriminado de ARGISSOLOS VERMELHO_AMARELOS Eutrófico, A moderado, textura média/argilosa pouco profundos. Unidade Manduca (Abruptic Paleudalf e Typic Paleudalf).

- Li_3 - NEOSSOLO LITÓLICO Eutrófico ou Distrófico, A moderado, proeminente ou chernozêmico, substrato sedimentos indiscriminados do Grupo Passa Dois. (Typic Udorthent).

- Li_5 - NEOSSOLO LITÓLICO Eutrófico, A moderado ou chernozêmico, substrato arenitos das Formações Botucatu ou Pirambóia.

- Li_6 - NEOSSOLO LITÓLICO Eutrófico, A moderado ou chernozêmico, substrato basalto ou diabásio. (Lithic Udorthent e Lithic Hapludoll) 


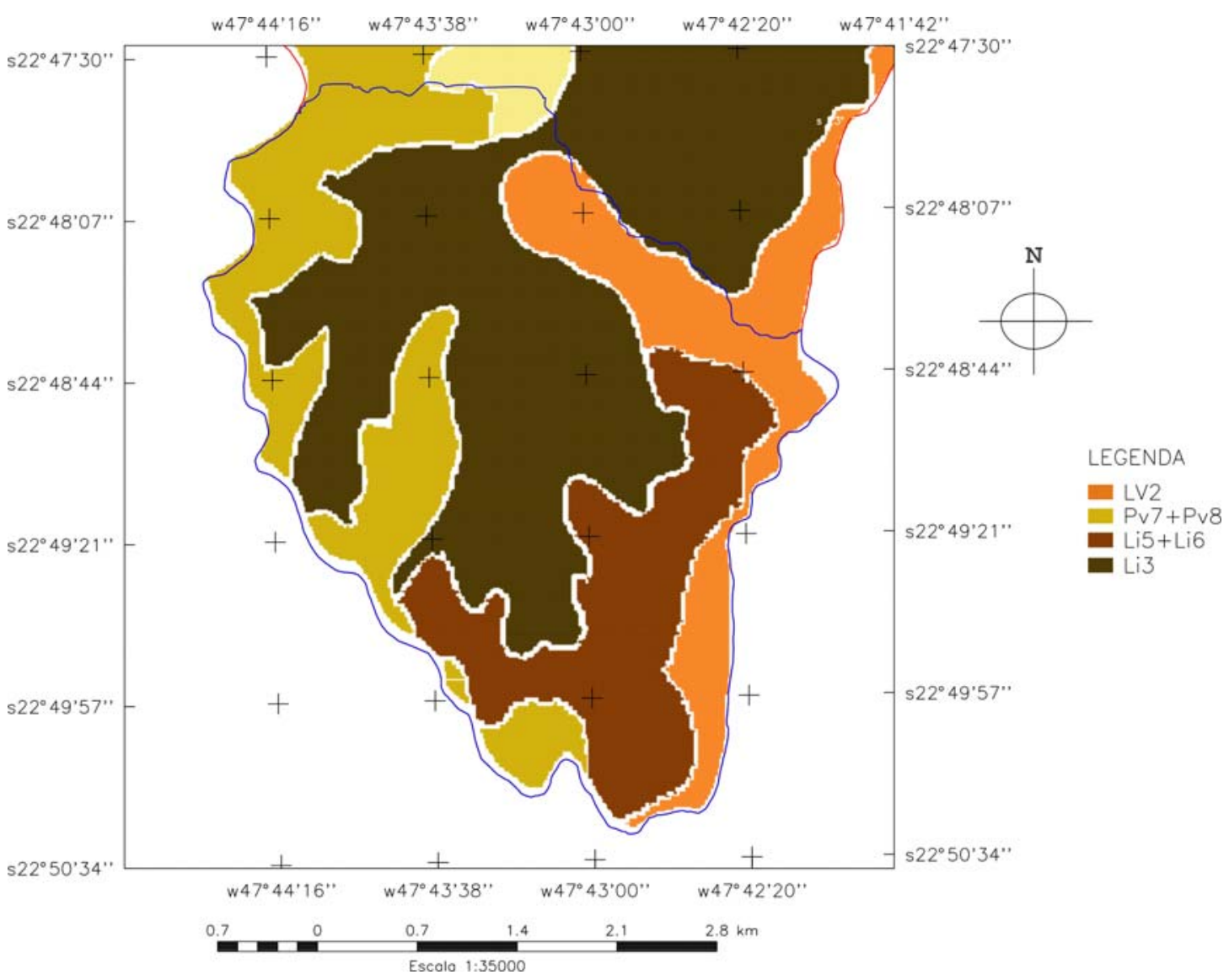

Figura 11 - Mapa pedológico

Tabela 1. Classes de solos

\begin{tabular}{cc}
\hline Solo & Área \% \\
\hline Li5 + Li6 & 20,53 \\
PV10+PV9 & 1,02 \\
PV7 & 14,78 \\
PV7+PV8 & 22,21 \\
Li3 & 41,06 \\
\hline
\end{tabular}




\subsubsection{Fotografias aéreas}

Para derivar os mapas de uso e cobertura do solo, assim como para a determinar o formato dos talhões foram adquiridas 15 fotografias aéreas correspondentes ao ano de 2000 , escala 1:25.000.

O recobrimento longitudinal (linha de vôo) entre as fotografias é de $60 \%$ e o lateral (faixas adjacentes) de $30 \%$.

Destas fotografias, foram digitalizadas 3 fotografias aéreas que recobriam a sub-bacia 1, que é a área específica deste estudo, e posteriormente foi realizado o mosaico das imagens (Figura 12).

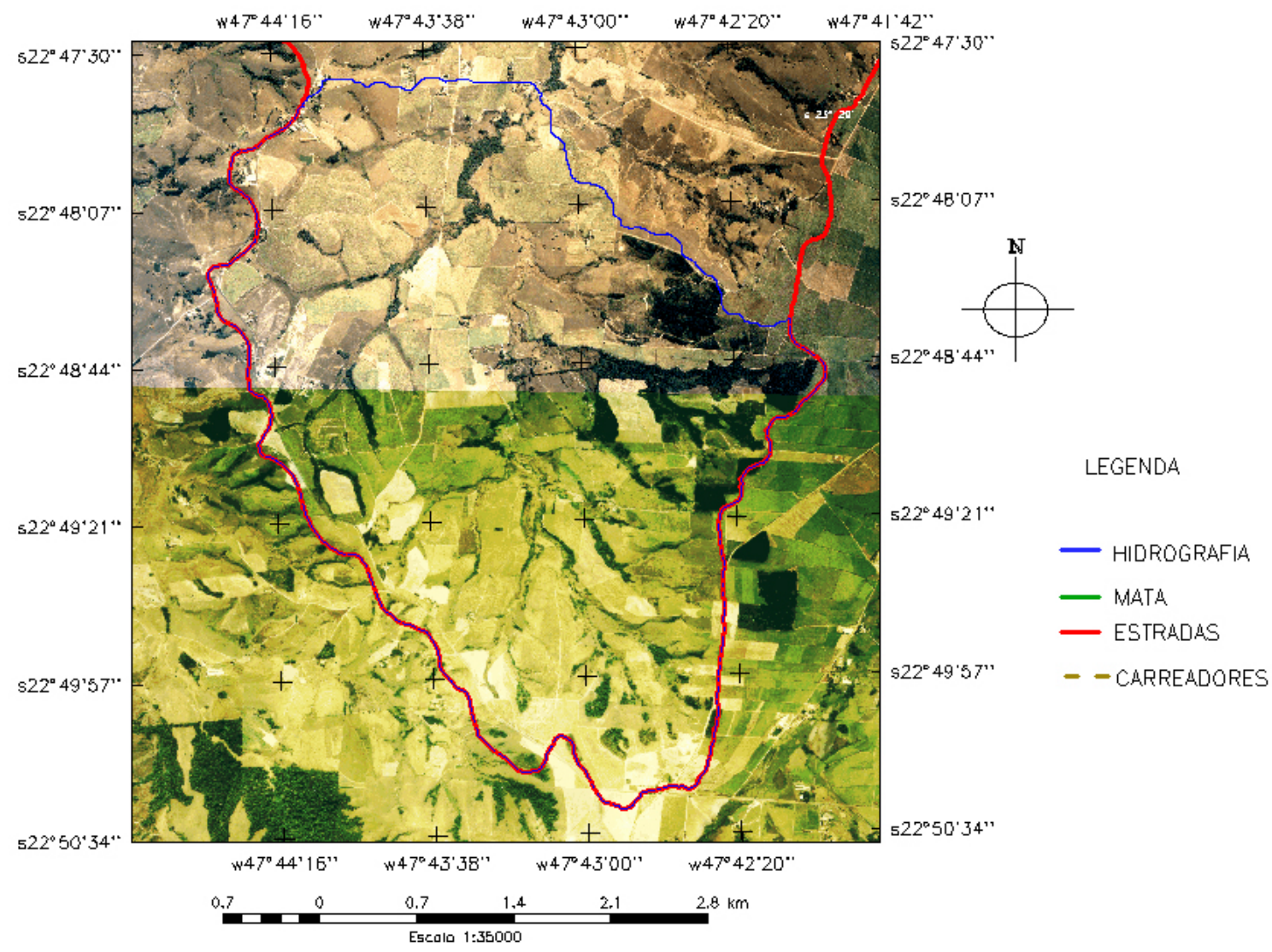

Figura 12 - Imagem proveniente de mosaico de fotografias aéreas 
3.1.4.4 Dados obtidos de DGPS

Foram coletados pontos amostrais para o registro das imagens, assim como para a identificação de feições especiais, tais como ravinas, voçorocas e áreas de risco ambiental.

\subsection{Metodologia}

Com o objetivo de criar um cenário com talhões e carreadores, para que fossem comparados com a realidade de campo, foram utilizados mapas de diversas fontes. $O$ fluxograma da metodologia é apresentado na Figura 13. 


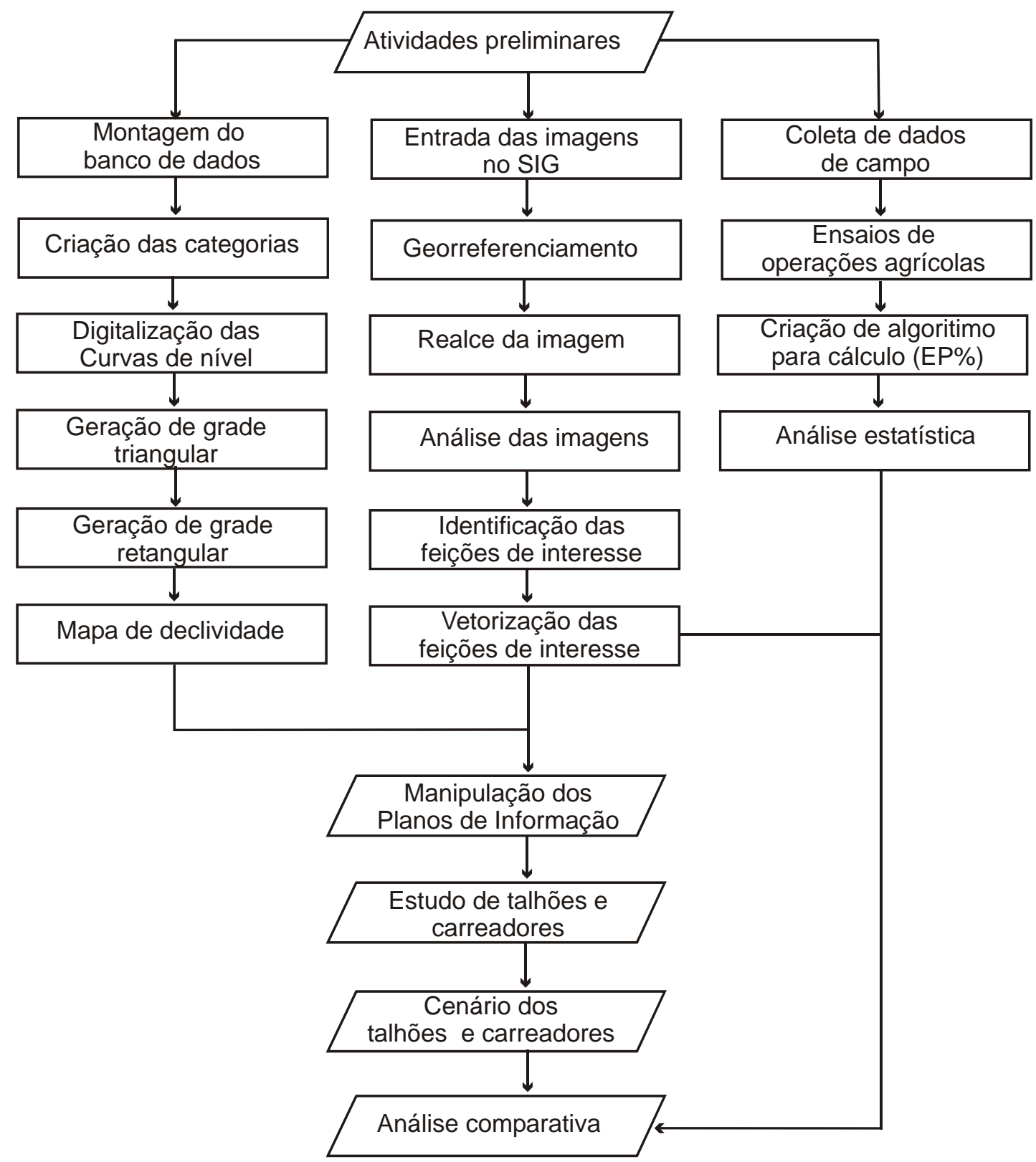

Figura 13 - Fluxograma da metodologia aplicada 


\subsubsection{Atividades preliminares}

Neste estágio, foi realizado o levantamento de dados da bacia do Ribeirão dos Marins, assim como a capacitação no software (SPRING), revisão bibliográfica e escolha das imagens. Foram estipulados os critérios, baseados na revisão bibliográfica, para a criação do SIG.

\subsubsection{Coleta de dados de campo}

Foram coletados pontos por DGPS, para o georreferenciamento das imagens provenientes de fotografias aéreas. Com um GPS de navegação foram coletados pontos com problemas de erosão (carreadores), nascentes e cursos d'água.

\subsubsection{Entrada das imagens no SIG}

As imagens provenientes de fotografias aéreas foram importadas pelo módulo de importação do SPRING, denominado IMPIMA. Foram inseridos parâmetros de resolução (1 metro) e as bandas de entrada e saída das imagens. O mesmo procedimento foi realizado para a imagem proveniente do sensor LANDSAT 7 ETM+, entretanto a resolução utilizada foi de 30 metros.

\subsubsection{Registro das imagens}

As imagens foram georreferenciadas pelos pontos de controle adquirido por DGPS. Os modos utilizados foram o teclado, para a entrada das coordenadas e pela imagem, com pontos de referência conhecidos por outras imagens.

\subsubsection{Realce das imagens}

As imagens foram realçadas pelo aumento linear de contraste, para que se evidenciassem os talhões e carreadores. 


\subsubsection{Análise das fotografias aéreas}

As imagens, provenientes de digitalização das fotografias aéreas, foram analisadas para o reconhecimento de feições de interesse (carreadores, drenagem, talhões, pastagem, etc.). Foram escolhidas as imagens que possuíam maior porcentagem de área com canaviais. De acordo com Marchetti, (1986), não existe classificação de revestimento e uso da terra que seja única e ideal. Cada classificação é feita de forma a atender as necessidades do usuário e adaptadas à região (Wolf, 1974).

- pasto: apresenta textura fina, homogênea e ligeiramente aveludada; tonalidade verde claro e médio. Aspectos associados: aguadas, bebedouros, cercas, currais, trilhas, árvores para sombreamento;

- cana-de-açúcar: textura fina ou aveludada; porte baixo ou médio; tonalidade verde médio e; apresenta-se distribuída em áreas de cultivo relativamente grandes, muito recortadas por carreadores;

- floresta: textura média e grossa; porte alto; tonalidade verde médio a escuro. Aspectos associados: telhado desuniforme; geralmente limites irregulares e ausência de carreadores;

- silvicultura: nesta categoria são consideradas as formações arbóreas homogêneas, instaladas pelo homem, para fins industriais ou para consumo dos estabelecimentos rurais; textura fina e média; porte médio a alto; tonalidade verde médio a escuro intenso. Aspectos associados: telhado uniforme, em geral limites regulares e carreadores definidos;

- culturas anuais: na época da tomada das fotografias aéreas aparece predominantemente como restos de cultura ou em processo de preparo do solo para o plantio, exceto quando se trata de culturas de inverno. Difere da cana-de-açúcar pela baixa ocorrência de carreadores, baixa subdivisão em glebas quando as áreas cultivadas são extensas, ausência de diferentes estágios de desenvolvimento simultâneos, curvas de nível mais freqüentes e evidentes dentro das glebas;

- culturas perenes: frutíferas em geral, cafezais etc; textura granular (fina e média); porte baixo e médio; tonalidade verde médio e escura. Aspectos associados: possibilidade de individualização das plantas em função do plantio uniforme com largos espaçamentos; configuração geométrica das glebas;

- urbanização: textura grosseira; tonalidade cinza médio e telhado não uniforme. Aspectos associados: quarteirões, ruas, prédios, casas, aspectos geométricos;

- hortifruticultura: culturas estaqueadas ou em canteiros. 
Áreas de interpretação duvidosa foram identificadas nas fotografias e visitadas no campo para determinar o seu uso corretamente.

\subsubsection{Processamento da imagem}

As técnicas utilizadas para melhorar os aspectos visuais da imagem e aumentar a acurácia da metodologia foram; aumento linear do contraste (Crosta, 1992), segmentação (Bins et al.,1996), transformação IHS (Campos, 2002), classificação não supervisionada (Richards, 1986), classificação não supervisionada (Venturieri, 1996), classificação supervisionada por Máxima Verossimilhança (Bins, 1993)

\subsubsection{Transformação IHS}

A imagem, inicialmente RGB (Red, Green e Blue), foi transformada para IHS (Intensity, Hue, Saturation), para que fosse segmentada a banda $\mathrm{H}$.

\subsubsection{Segmentação da banda $H$}

A segmentação da banda $\mathrm{H}$ delineou os talhões e carreadores de modo a facilitar a identificação dos mesmos. A rede hidrográfica também foi evidenciada.

\subsubsection{Classificação da imagem realçada e segmentada}

Os talhões foram classificados de acordo com os tons de cinza (0-255). 


\subsubsection{Classificação supervisionada do mapa de solos}

Os solos foram classificados, tendo como base o mapa do Projeto Piracena (2001) e as referências de Prado (2002).

\subsubsection{Avaliação do mapeamento}

Os mapas foram avaliados e, quando não atendiam as qualidades almejadas, foram refeitos.

\subsubsection{Montagem do banco de dados}

Os dados geográficos foram agrupados e armazenados no banco de dados (Access) de acordo com os padrões do software SPRING. As categorias e seus respectivos Planos de Informação são apresentados esquematicamente na Figura 14:

\begin{tabular}{|l|l|}
\hline Categorias & Planos de Informação (PI's) \\
\hline $\begin{array}{l}\text { Imagens: Armazenamento das imagens } \\
\text { provenientes de fotografias aéreas e imagens } \\
\text { de satélite. O formato desta categoria é raster. }\end{array}$ & IMG IMG 2, IMG 3, IMG 4, IMG 5, IMG_sat, \\
\hline MNT: O modelo numérico do terreno & $\begin{array}{l}\text { Curvas de nível, linhas de quebra, grade } \\
\text { regular, grade triangular e declividade }\end{array}$ \\
\hline $\begin{array}{l}\text { Temático: Nesta categoria são agrupados os } \\
\text { mapas resultantes de imagens classificadas e } \\
\text { segmentadas, assim como os mapas } \\
\text { importados no formato shape (.shp) }\end{array}$ & $\begin{array}{l}\text { Declividade, Imagem sombreada, mapa } \\
\text { drenagem, bacia, estradas e talhões. }\end{array}$ \\
\hline Cadastral: Objetos ligados ao banco de dados & Talhões atuais, talhões propostos. \\
\hline Objeto: Objetos cadastrais & Talhões atuais, talhões propostos. \\
\hline $\begin{array}{l}\text { Rede: Objetos vetoriais para roteirização de } \\
\text { percursos }\end{array}$ & Carreadores e estradas rurais \\
\hline
\end{tabular}

Figura 14 - Categorias e Pl's do banco de dados do sistema 


\subsubsection{Digitalização das curvas de nível}

As linhas das curvas foram vetorizadas e nelas foram atribuídas cotas. Deste mapa foi elaborado o mapa de declividade. Para esta PI, foram categorizados, de acordo com os critérios já consagrados em: < 3\%, $3-6 \%, 6-12 \%$ e > 12\%. Para a elaboração desta PI, foi utilizado o seguinte procedimento (Figura 15):

- Digitalização das curvas de nível, com linhas de quebra (hidrografia);

- Geração de grade triangular;

- Geração de grade regular;

- Fatiamento (divisão em classes). 


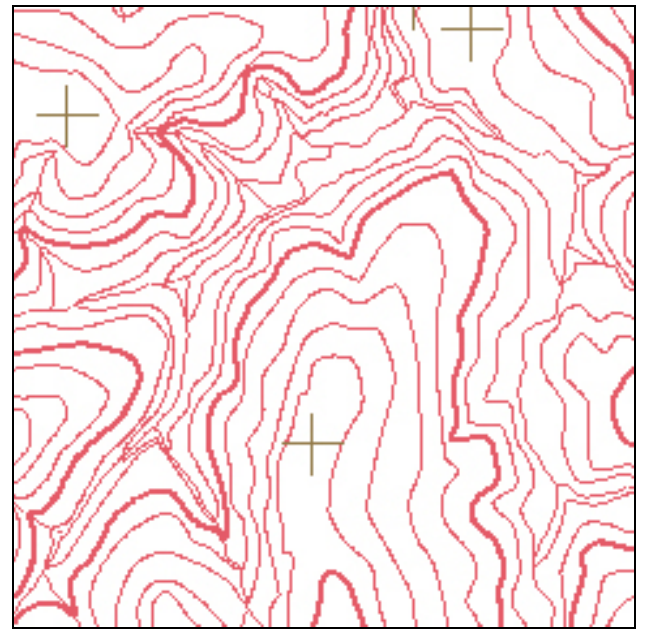

Curvas de nível

\begin{tabular}{|c|c|c|c|c|c|}
\hline$\stackrel{5411}{+}$ & 537.2 & $\underset{+}{534} 1$ & $\stackrel{531.1}{+}$ & $\underset{+}{525.5}$ & $\stackrel{5245}{+}$ \\
\hline$\stackrel{540,8}{+}$ & $\underset{+}{5.3 .3 .0}$ & $\underset{+}{526,4}$ & $\underset{+}{s 24,3}$ & $\underset{+}{520.2}$ & 518,5 \\
\hline $\begin{array}{l}541.3 \\
+\end{array}$ & $\begin{array}{r}5.35 .7 \\
+\end{array}$ & $\begin{array}{r}5.516 \\
+\end{array}$ & $\begin{array}{r}526.4 \\
+\end{array}$ & 522.0 & $5177^{\circ}$ \\
\hline$\underset{+}{54 G, 2}$ & 537.8 & $\underset{+}{5.34 .7}$ & 552.8 & $\begin{array}{c}524,6 \\
+\end{array}$ & $\underset{+}{520.1}$ \\
\hline$\underset{+}{539.1}$ & 537.7 & $\begin{array}{c}5.35 .1 \\
+\end{array}$ & $\underset{+}{5.3 .3 .2}$ & $\underset{+}{529.8}$ & $\underset{+}{523,6}$ \\
\hline$\stackrel{5377}{+}$ & $\stackrel{536.1}{+}$ & $\underset{+}{5346}$ & $\stackrel{532.2}{+}$ & $\stackrel{529.3}{+}$ & $\begin{array}{c}526 \\
+\end{array}$ \\
\hline $\begin{array}{c}5.37,0 \\
+\end{array}$ & $5 \underset{+}{5} 5.0$ & $\begin{array}{c}5.33 .5 \\
+\end{array}$ & $\underset{+}{551.5}$ & 528.1 & $\begin{array}{r}526.7 \\
+\end{array}$ \\
\hline
\end{tabular}

Grade regular

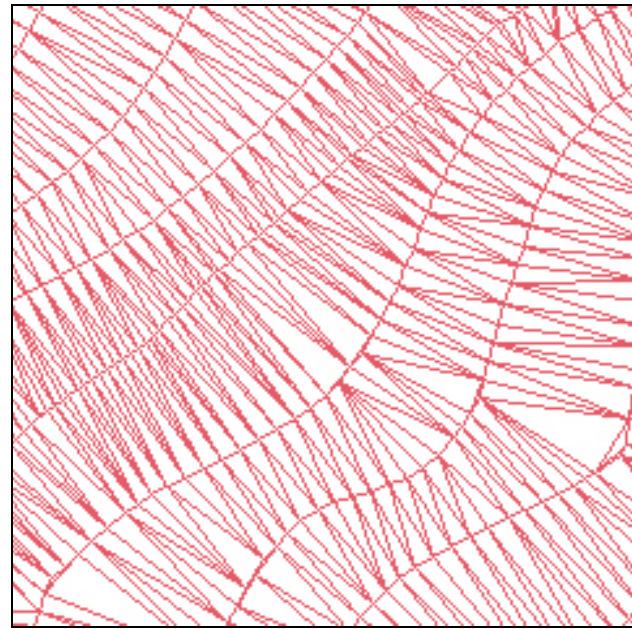

Grade triangular (TIN)

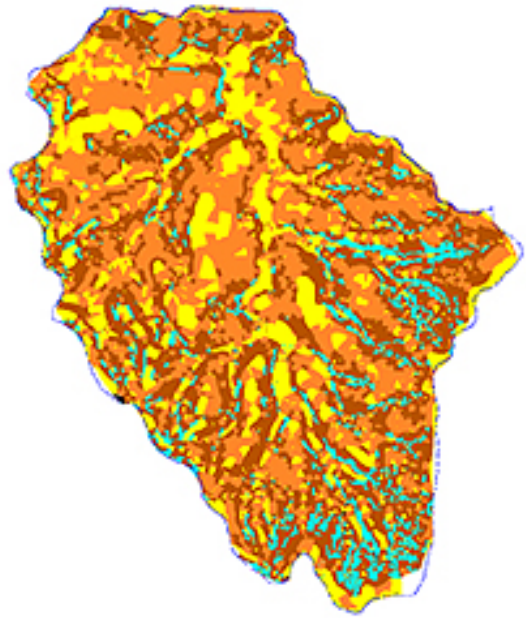

Mapa de declividade

Figura 15 - Metodologia para a obtenção do mapa de declividade em \% 


\subsubsection{Vetorização de polígonos}

Os polígonos referentes aos talhões, obtidos com o uso das fotografias aéreas foram transformados em objetos vetoriais, estando vinculado a uma tabela do banco de dados. As propriedades também foram vetorizadas e inseridas no banco de dados.

\subsubsection{Cruzamento dos planos de informação}

Os planos de informação foram cruzados pelo módulo de programação em LEGAL, apresentado na Figura 16 e 17.

//Cruzamento entre os planos temáticos de declividade e área de cana

\{

//Definindo as variáveis e suas categorias

Tematico decliv("declividade"), talhao("talhoes"), apti("aptidao");

//Recuperando planos

decliv=Recupere (Nome = "fatiamento");

talhao=Recupere (Nome = "talhonamento");

//Criando novo plano

apti=Novo(Nome="apt_pp", ResX=10, ResY=10, Escala=3000);

//Definindo as relações entre classes

apti = Atribua (CategoriaFim = "aptidao")

\{

"varzea": (talhao.Classe == "proposta" \&\& decliv.Classe == "0-3"),

"mecanizável": (talhao.Classe == "proposta" \&\& decliv.Classe == "3-6"),

"mecanizável_restri": (talhao.Classe == "proposta" \&\& decliv.Classe == "6-12"),

"impropria": (talhao.Classe == "proposta" \&\& decliv.Classe == "12 - 18")

\}

\}

Figura 16 - Programa em LEGAL para a obtenção do mapa de aptidão na área total de cana 
/Cruzamento entre os planos temáticos propriedades e talhões

\{

//Definindo as variáveis e suas categorias

Tematico talh("talhoes"), prop("talhoes"), percent("prop_alg");

//Recuperando planos

talh=Recupere (Nome = "prop_alg");

prop=Recupere (Nome = "propriedades");

//Criando novo plano

percent=Novo(Nome="percent", ResX=10, ResY=10, Escala=3000);

//Definindo as relações entre classes

percent $=$ Atribua $($ CategoriaFim $=$ "prop_alg")

\{

"talhao26": (talh.Classe == "26" \&\& prop.Classe == "p119c"),

"talhao27": (talh.Classe == "27" \&\& prop.Classe == "p119c"),

"talhao28": (talh.Classe == "28" \&\& prop.Classe == "p119c")

\}

\}

Figura 17 - Programa em LEGAL para determinação da porcentagem da área dos talhões 26,27 e 28 que estão presentes na propriedade 119 


\subsubsection{Critérios teóricos para a elaboração das PI's}

Os critérios utilizados para a elaboração dos Pl's são apresentados no organograma (Figura 18).
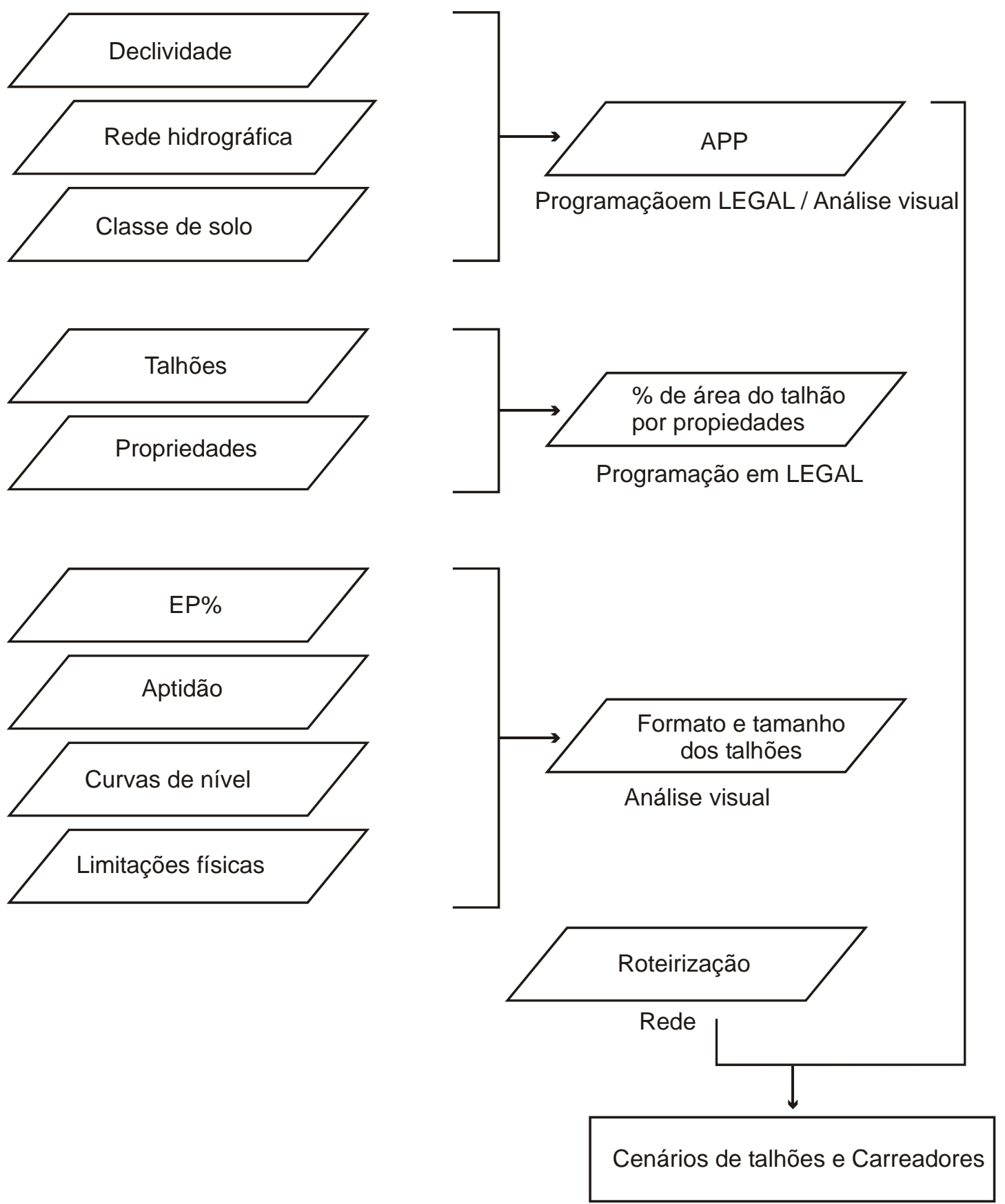

Figura 18 - Cruzamento dos planos de informação 


\subsubsection{APP}

Este plano de informação teve como objetivo criar um mapa restritivo, de acordo com a legislação vista anteriormente. De acordo com a Lei $n^{\circ} 4.771 / 65$, que determina a proteção de florestas nativas e define as Áreas de Preservação Permanente (onde a conservação da vegetação é obrigatória): uma faixa de 10 a 500 metros nas margens dos rios (dependendo da largura do curso d'água), beira de lagos e de reservatórios de água. Neste trabalho, à distância considerado foi de 30 metros em relação à hidrografia. Foram utilizados os seguintes PI para a obtenção deste mapa temático: hidrografia, declividade e classe de solo.

\subsubsection{Classes de solos}

Os solos foram discretizados, segundo suas características físicas e químicas mostradas na tabela 3. O mapa base utilizado para foi convertido em TM para o fatiamento em classes de declive.

\subsubsection{Formato e tamanho dos talhões}

Esta PI foi elaborada em função das classes de solos, tendo em vista os ambientes de produção (Prado, 1996). O mapa base utilizado foi o de classes de solos Projeto Piracena (2001).

\subsubsection{Eficiência de percurso}

O formato e o tamanho dos talhões foram considerados de acordo com os critérios estabelecidos por Mialhe (1974), e indicados na revisão bibliográfica. 


\subsubsection{Planejamento da base física}

Este plano de informação foi elaborada a partir do mapa de declividade e, segundo critérios propostos por Mialhe (1974) e Furlani Neto (1994), que são:

- comprimento dos talhões: o qual tem, no sistema manual, comprimento de 200 a 300 $\mathrm{m}$ e que precisam ser modificados para $400 \mathrm{~m}$ ou mais para aumentar o rendimento das operações, ocasionado pela redução das manobras de cabeceira e estabilização da velocidade média;

- sistematização dos terrenos: consiste em nivelar o terreno antes do plantio para evitar as micro-ondulações que impedem uma melhor evolução da velocidade média da colhedora e prejudicam o corte basal correto dos colmos;

- curvas de nível: As curvas de nível serviram como mapa base para determinação do formato dos talhões que de acordo com Furlani Neto (1996), a forma de se fazer as linhas dos sulcos, que devem seguir paralelas às curvas de nível, evitando-se a presença dos "bicos", sulcos que vão diminuindo de tamanho e que implicam em aumento de manobras da colhedora e do veículo de carga sobre o talhão.

\subsubsection{Limitações físicas}

Foram detectados pontos onde limitações físicas impediriam o acesso de máquinas agrícolas tais como: estradas, cercas, construções rurais, etc.

\subsubsection{Roteirização}

Os pontos de escoamento de produção são considerados obrigatórios, considerando as estradas rurais e a localização da Usina Santa Helena. Esta PI foi inserida na categoria "REDE", possibilitando o acesso à base de dados e fornecendo os melhores percursos, de acordo com as distâncias e as impedâncias. 


\subsection{Ensaios de campo}

Foram realizados dois ensaios de campo na microbacia dos Marins, com o objetivo de mensurar o tempo de manobra de duas operações agrícolas para a cultura da cana-de-açúcar; adubação e aplicação de herbicida. Ambas foram realizadas no mês de julho, época em que também a operação de colheita. Com os tempos médios gastos nas operações, foram estimados para todos os talhões, os observados nas fotografias aéreas e os propostos.

\subsubsection{Ensaio 1}

Para a aplicação de herbicida, a faixa de deposição do implemento foi de $7 \mathrm{~m}$ (Tabela 2), com duas hastes laterais dobráveis. Quando o operador vai virar o conjunto máquina/implemento, as hastes são erguidas de modo que ela fique perpendicular ao solo e não se encoste à lavoura do talhão ao lado. Entretanto, em algumas manobras a haste "enrosca" (manobra 2 e 4) no cabo que a suspende, resultando uma manobra mais lenta. $\mathrm{Na}$ Tabela 3, são apresentados os tempos cronometrados no ensaio.

Tabela 2. Ensaio de campo para a observação do tempo médio gasto com manobras de cabeceira para a operação de aplicação de herbicida

\begin{tabular}{cc}
\multicolumn{2}{c}{ operação de aplicação de herbicida } \\
\hline \multicolumn{2}{c}{ Ensaio 1} \\
\hline Operação & Aplicação de Herbicida \\
Produtor/Operador & Nelson Nadia \\
Trator & Massey 290 \\
Ciclo operacional & Unidirecional aberto \\
Faixa de deposição & $7 \mathrm{~m}$ \\
Rotação do motor & 1.100 R.P.M \\
\hline
\end{tabular}


Tabela 3. Tempo de manobra observado no campo para a operação aplicação de herbicida

\begin{tabular}{cc}
\hline Manobra & Tempo (s) \\
\hline 1 & 54,00 \\
2 & 127,00 \\
3 & 57,00 \\
4 & 108,00 \\
5 & 55,00 \\
6 & 102,00 \\
Média & 83,83 \\
Melhor tempo & 54,00 \\
Pior tempo & 127,00 \\
\hline
\end{tabular}

\subsubsection{Ensaio 2}

Para a aplicação de fertilizante, a largura de deposição foi de $2,8 \mathrm{~m}$ (duas ruas), e o ciclo operacional adotado foi o fechado. Os dados referentes ao conjunto máquina/implemento são apresentados na Tabela 4, e tempo de manobra para a operação citada na Tabela 5.

Tabela 4. Ensaio de campo para a observação do tempo médio gasto com manobras de cabeceira para a operação de adubação

\begin{tabular}{cc}
\hline & Ensaio 2 \\
\hline Operação & Adubação \\
Produtor/Operador & Júlio Zampaulo \\
Trator & New Holand 7630 \\
Ciclo operacional & Unidirecional fechado \\
Largura de trabalho & $2,8 \mathrm{~m}$ \\
Rotação do motor & 1.700 R.P.M \\
\hline
\end{tabular}


Tabela 5. Tempo de manobra em uma operação de adubação

\begin{tabular}{cc}
\hline Manobra & Tempo (s) \\
\hline 1 & 15,00 \\
2 & 17,00 \\
3 & 12,00 \\
4 & 16,00 \\
5 & 16,00 \\
6 & 23,00 \\
7 & 16,00 \\
Média & 16,43 \\
Melhor tempo & 12,00 \\
Pior tempo & 23,00 \\
\hline
\end{tabular}

A tabela foi elaborada em excel e inserida o algoritmo para cálculo da eficiência de percurso. Posteriormente, a tabela foi exportada em dbf.IV e inserida no banco de dados do sistema criado para consultas espaciais de atributos qualitativos. 


\section{RESULTADOS E DISCUSSÃO}

Neste capítulo são apresentados os resultados do mapeamento dos talhões da subbacia 1 da microbacia dos Marins, assim como os planos de informação descritos no capítulo anterior. São apresentados também os resultados estimados do cenário proposto, e por fim a comparação com o modelo adotado.

Na bibliografia consultada, não foi encontrado nenhum trabalho que relacionasse eficiência de operações agrícolas com formato geométrico de talhões, utilizando Sistema de Informações Geográficas.

\subsection{Situação atual}

As feições de interesse (uso do solo, área total dos talhões de cana-de-açúcar, a geometria das quadras, relação comprimento/largura, paralelismo às curvas de nível e eficiência de percurso) foram discriminadas e analisadas observando-se as imagens provenientes de fotografias aéreas.

\subsubsection{Talhões}

Com base nas imagens provenientes das fotografias aéreas, foi criado um plano de informação, contendo todos os talhões identificados na área (Figura 19). Estas informações foram classificadas para poder ser calculado:

- a área de cultivo (área total dos talhões);

- a eficiência de percurso;

- tempo de manobra. 


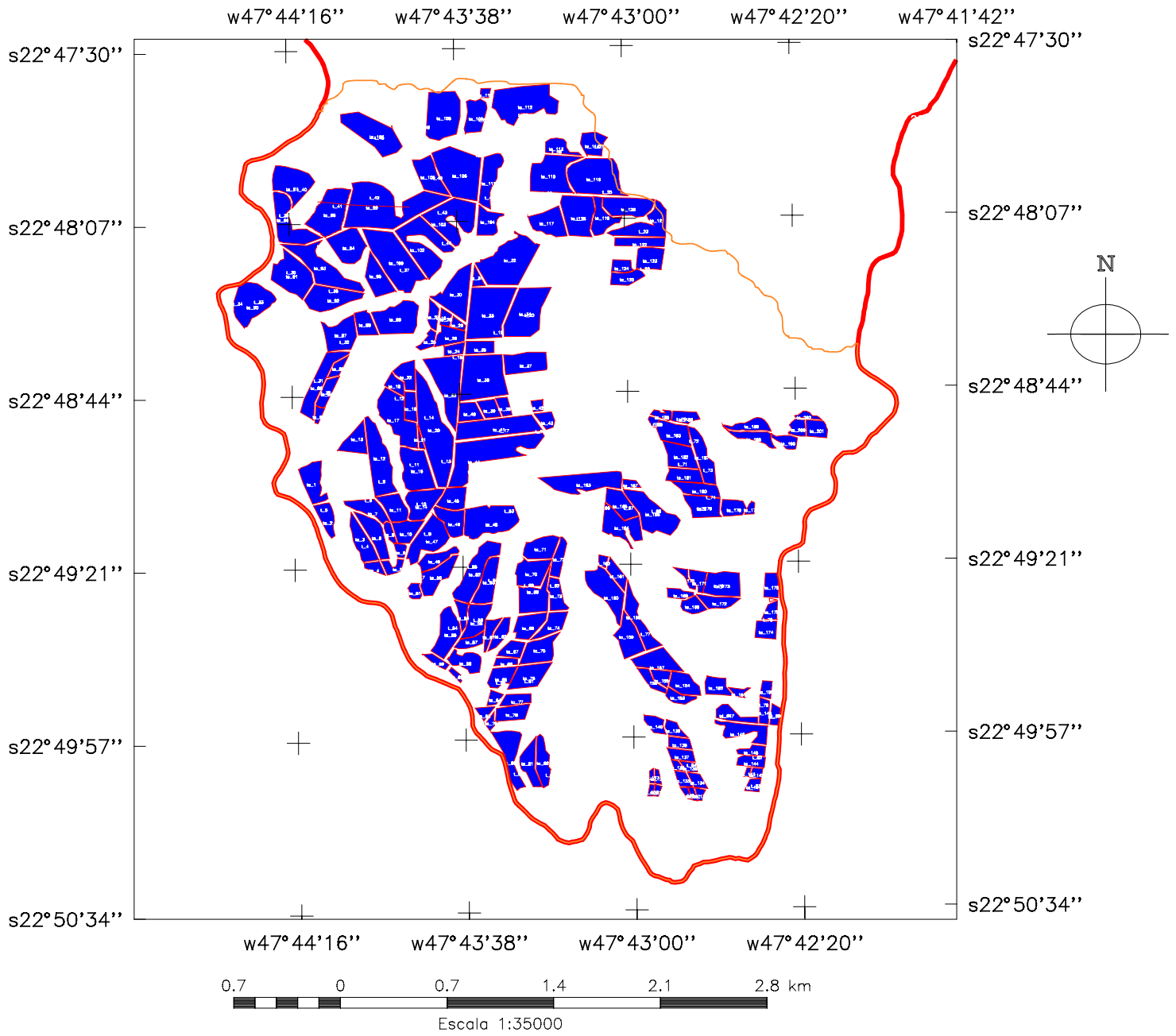

Figura 19 - Talhões identificados na área de estudo 
Tabela 6. Área dos talhões obtidas por sensoriamento remoto

\begin{tabular}{cc}
\hline Critério & Área (ha) \\
\hline Total & 448,81 \\
Média & 2,44 \\
Maior & 11,66 \\
Mínimo & 0,18 \\
\hline
\end{tabular}

TAMANHO DOS TALHÕES

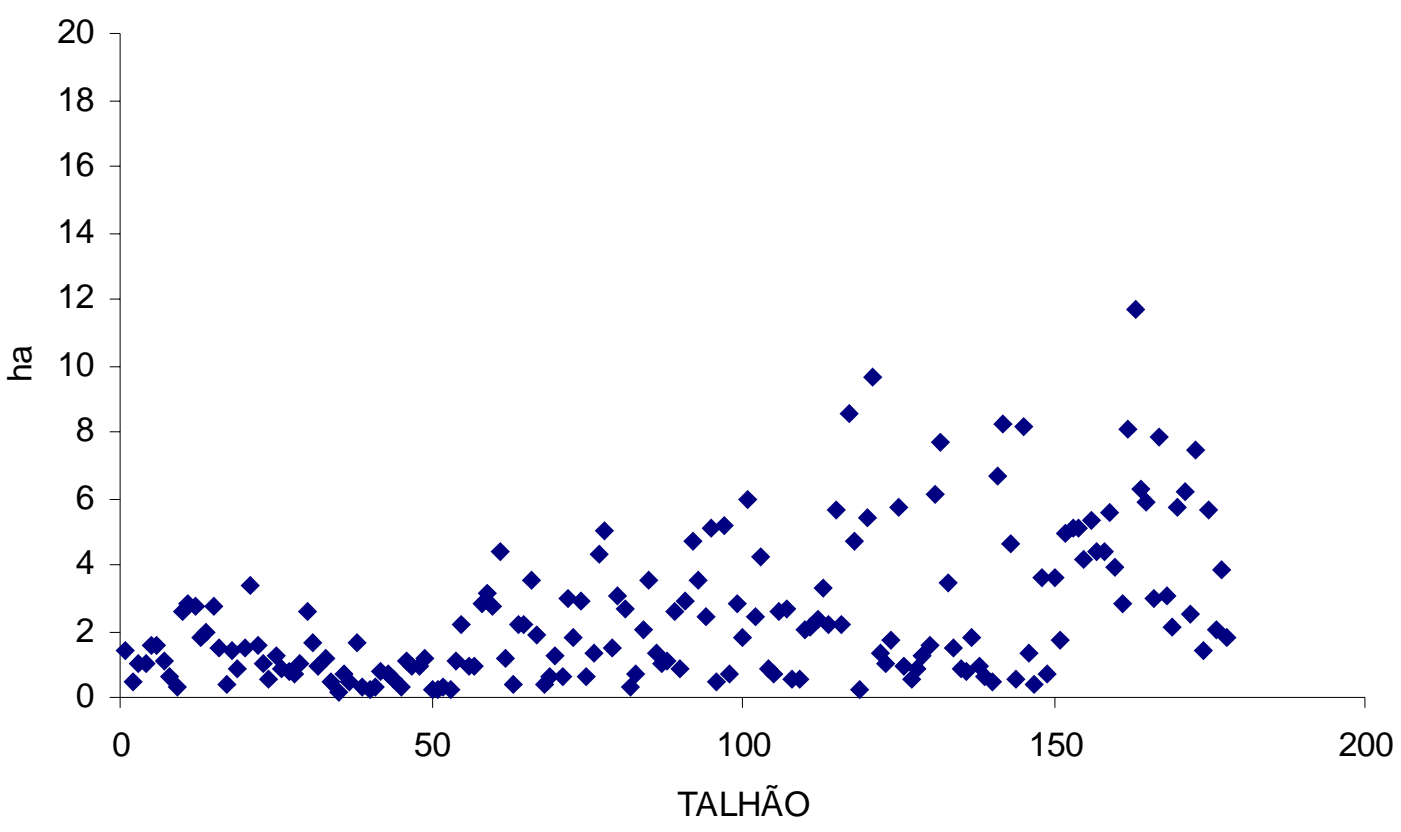

Figura 20 - Representação gráfica do tamanho dos talhões observados na área de estudo 


\subsubsection{Carreadores e estradas vicinais}

A extensão total dos carreadores na área de estudo é de 115,46 Km. As cartas do IBGE e as imagens provenientes das fotografias aéreas subsidiaram a elaboração deste plano de informação.

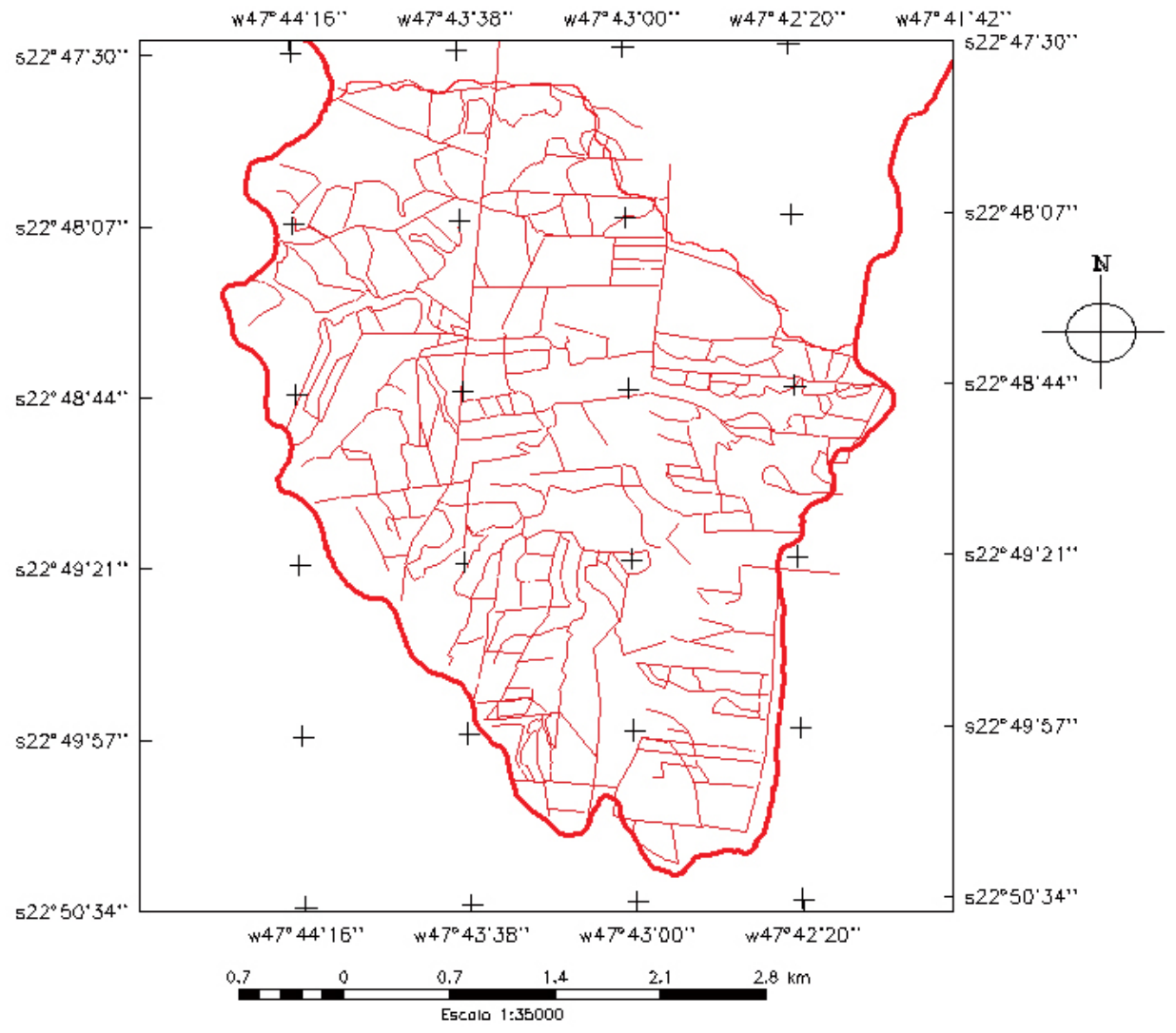

Figura 21 - Traçado de carreadores e estradas vicinais 


\subsubsection{Vegetação remanescente}

A microbacia possui uma área reduzida de vegetação remanescente, assim como pouca Mata Ciliar ao entorno do ribeirão do Marins. Foram observadas algumas regiões assoreadas devido à escassez de mata ciliar.

Na Figura 21 a região verde indica a região onde foi identificada 120,07 ha de vegetação remanescente e de mata ciliar.

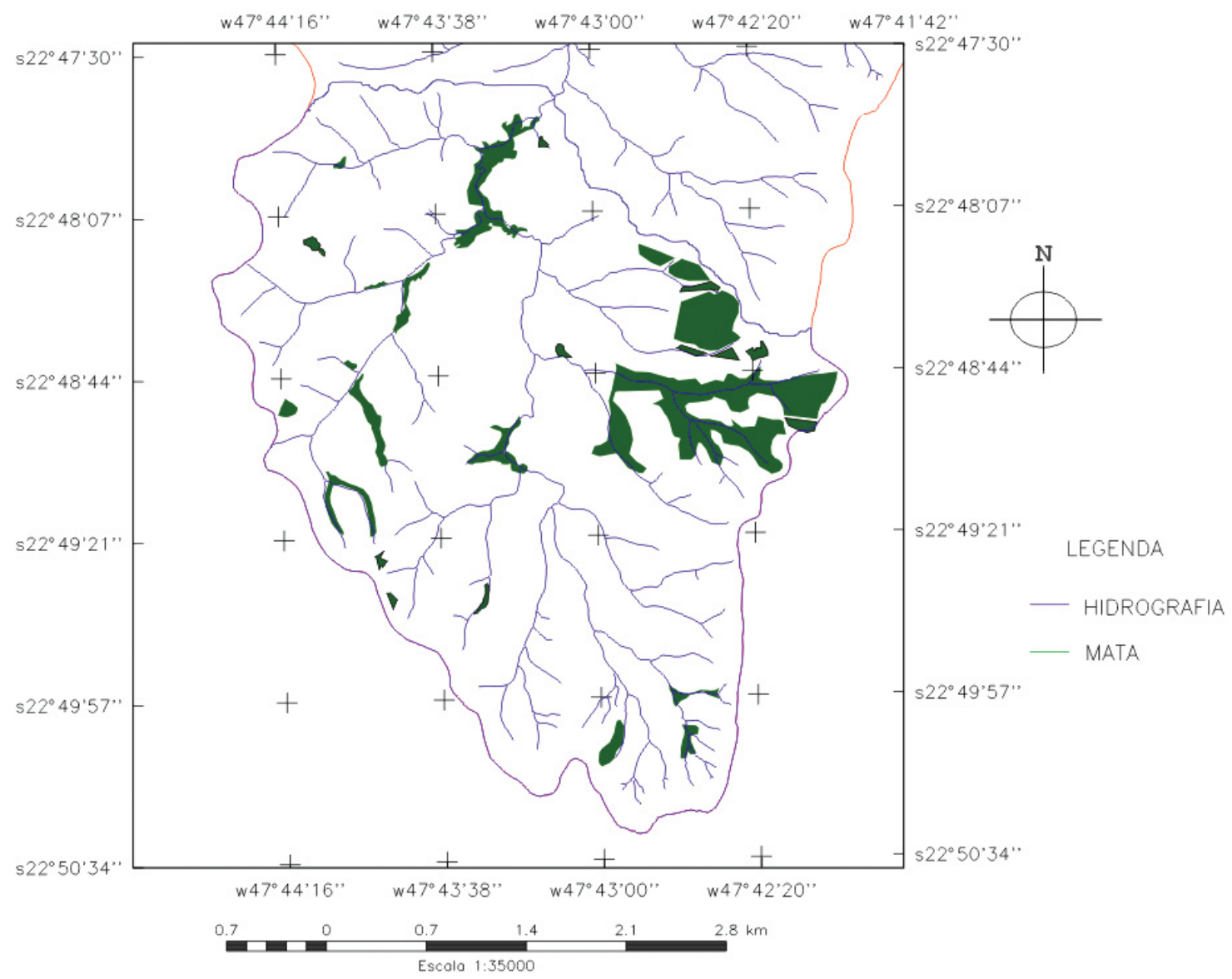

Figura 22 - Vegetação remanescente da área de estudo 


\subsubsection{Mapa temático de aptidão}

A região pode ser considerada, analisando-se o plano de informação elaborado, como ondulada. A declividade é considerada por De Biasi (1998) como uns dos principais fatores de erosão do solo, assim como determinante para algumas operações agrícolas, entre elas a colheita mecanizada.

TALHÕES

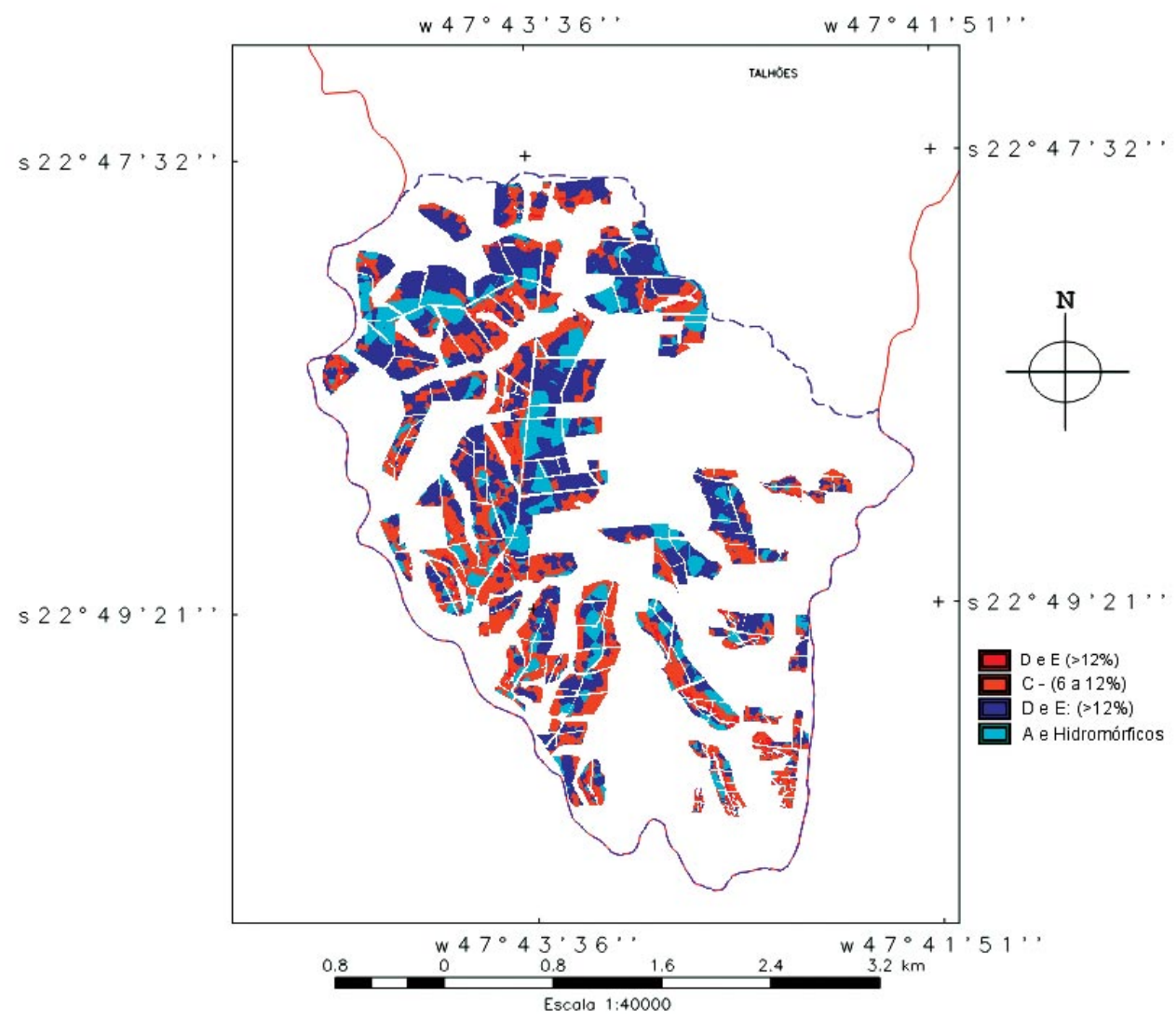

Figura 23 - Mapa de aptidão da área de cana-de-açúcar

Tabela 7. Aptidão da área na qual é cultivada cana-deaçúcar

\begin{tabular}{cc} 
açúcar & Área (ha) \\
\hline Classe & 85,89 \\
A e Hidromórficos & 207,73 \\
B: $(3$ a 6\%) & 153,68 \\
C: (6 a 12\%) & 16,70 \\
D e E: (>12\%) & 464,00 \\
Area total das classes & \\
\hline
\end{tabular}




\subsubsection{Propriedades rurais}

As propriedades rurais (Figura 24) são fornecedoras de cana-de-açúcar da Usina Santa Helena, sendo a maioria delas de pequeno porte, com seus valores mostrados na Tabela 8. A representação gráfica é apresentada na Figura 25.

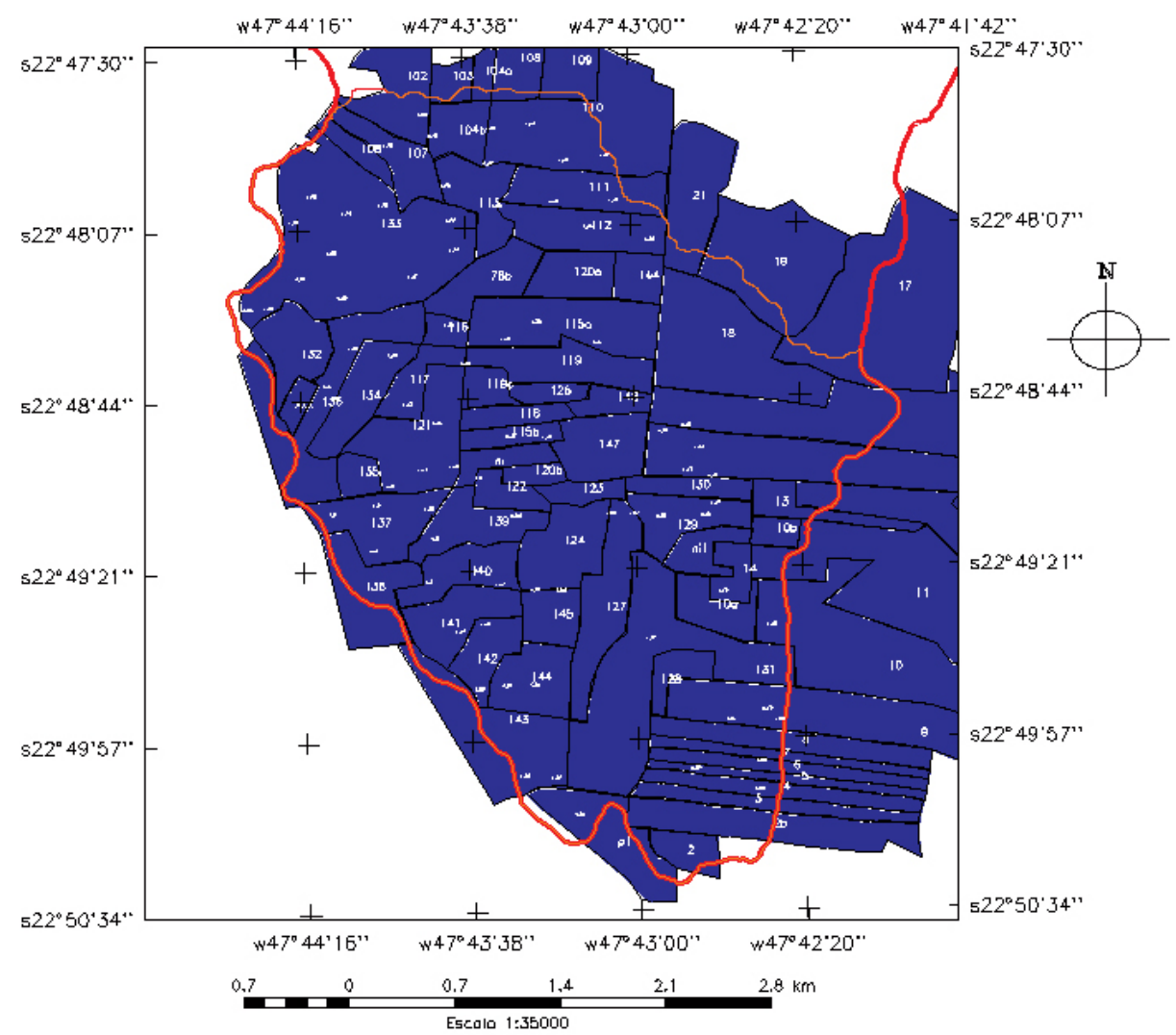

Figura 24 - Propriedades rurais da região da área de estudo 
Tabela 8. Dados estatísticos do conjunto das 73 propriedades rurais, presentes na área de estudo

\begin{tabular}{cc}
\hline Criterio & Área (ha) \\
\hline Média & 29,37 \\
Mediana & 20,32 \\
Menor & 4,65 \\
Maior & 135,97 \\
Área total & $2.144,34$
\end{tabular}

TAMANHO DAS PROPRIEDADES

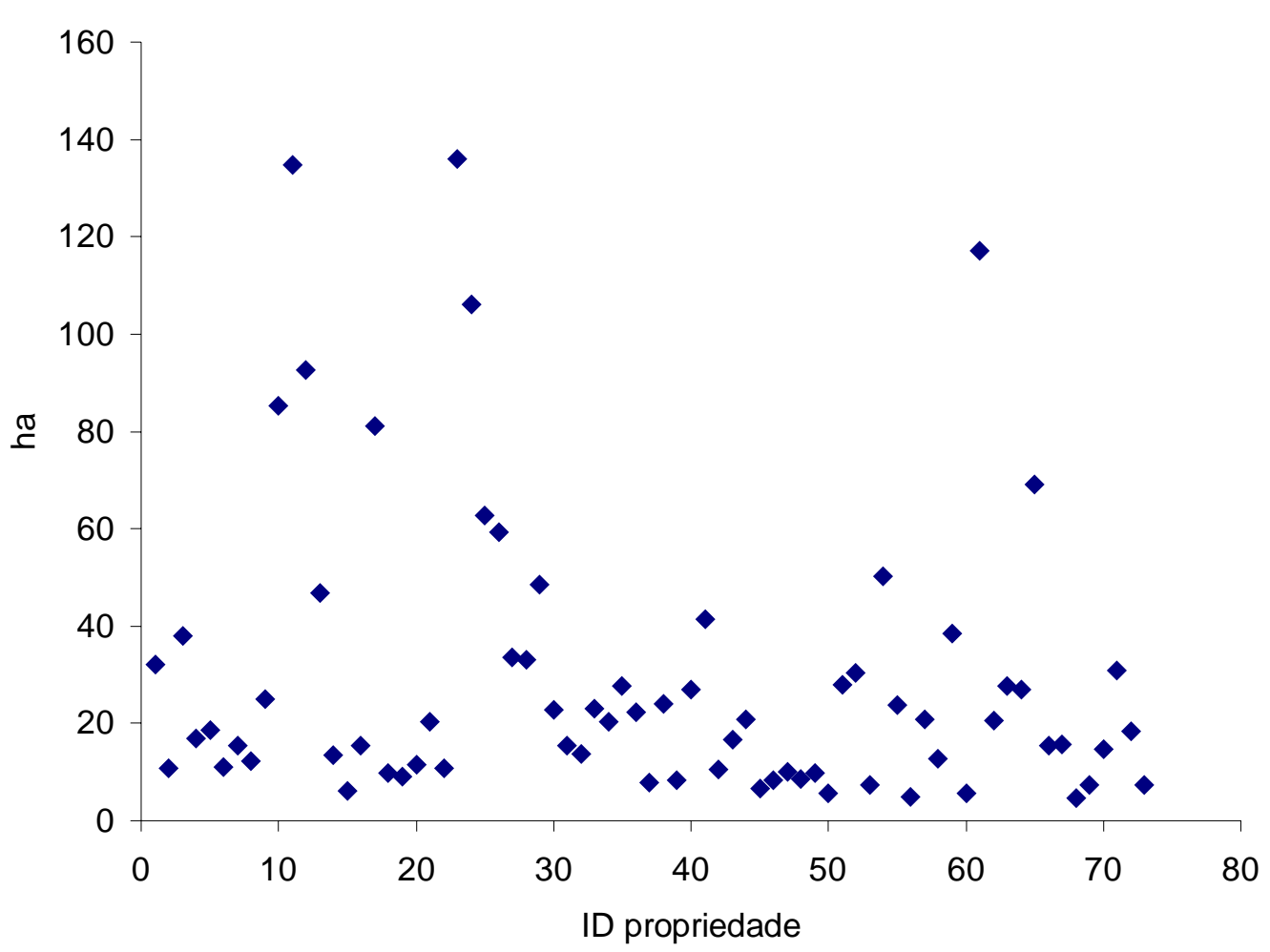

Figura 25 - Tamanho (ha) das propriedades rurais presentes na área de estudo 


\subsubsection{Tempo de manobra}

\subsubsection{Aplicação de herbicida}

O tempo de manobra (Tabela 9) foi estimado a partir de um ensaio de campo, realizado na microbacia dos Marins. O cálculo foi realizado considerando a largura de trabalho do implemento, a largura do talhão e a média do tempo de manobra, observada no campo. A representação gráfica é apresentada na Figura 26.

Tabela 9. Tempo estimado de manobra para a aplicação de herbicida para os 189 talhões observados

\begin{tabular}{cc}
\hline Dados estatísticos & Tempo (s) \\
\hline Média & $32^{\prime} 27^{\prime \prime}$ \\
Mínimo & $5^{\prime} 46^{\prime \prime}$ \\
Máximo & $66^{\prime} 32^{\prime \prime}$ \\
Total & $6.132^{\prime} 49^{\prime \prime}$ \\
\hline
\end{tabular}

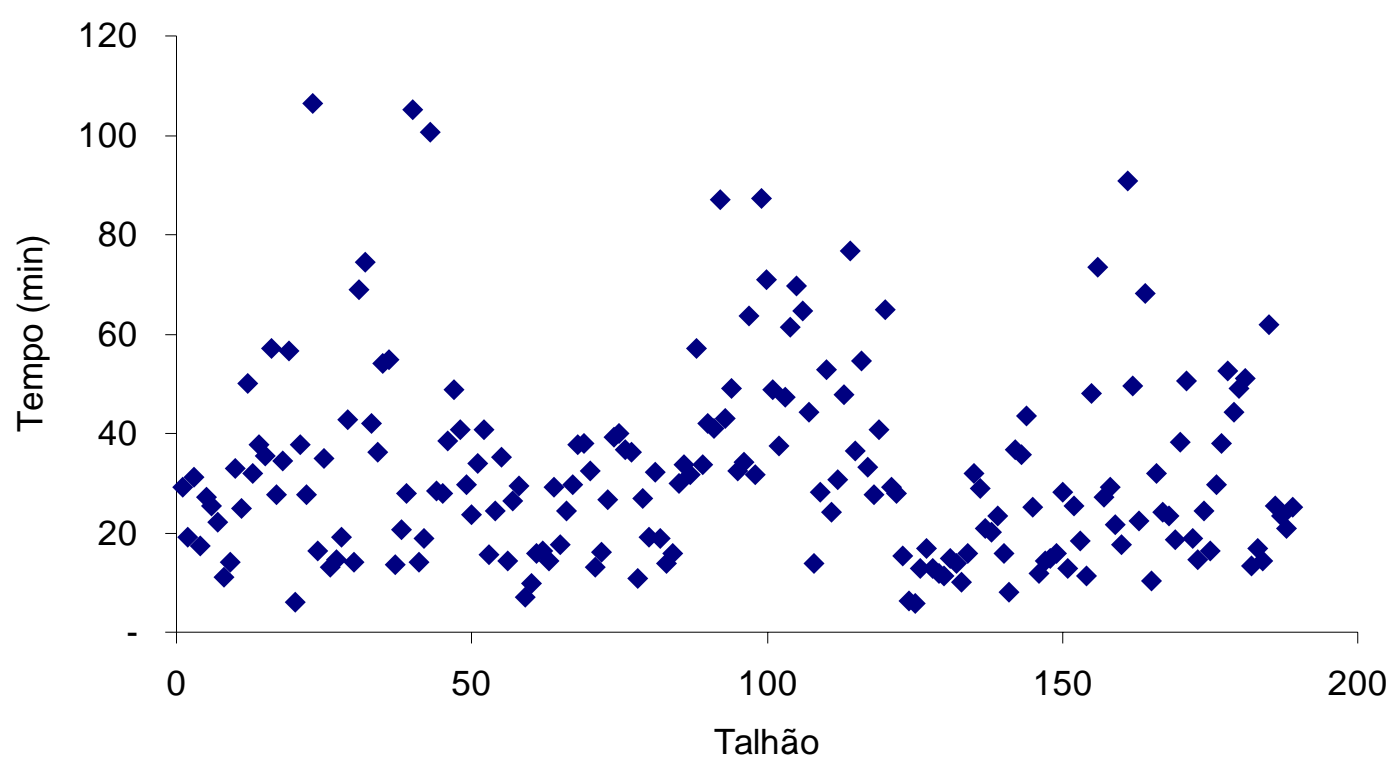

Figura 26 - Tempo estimado em manobras de cabeceira para operação de aplicação de herbicida 


\subsubsection{Adubação}

O tempo estimado de manobra de cabeceira para adubação foi calculado utilizando-se o mesmo procedimento para a estimativa do tempo de manobra para a aplicação de herbicida. Entretanto, pela diferença estrutural do implemento, o movimento das máquinas tem uma dinâmica mais ágil, demandando menos horas/máquina para a realização do trabalho, como é mostrado na Tabela 10 e na Figura 27.

\begin{tabular}{cc}
$\begin{array}{c}\text { Tabela 10. Tempo estimado de manobra para adubação em } \\
189 \text { talhões }\end{array}$ \\
\hline Dados estatísticos & Tempo (min) \\
\hline Média & $21^{\prime} 17^{\prime \prime}$ \\
Mínimo & $5^{\prime} 57^{\prime \prime}$ \\
Máximo & $49^{\prime} 30^{\prime \prime}$ \\
Desvio Padrão & $8^{\prime} 58^{\prime \prime}$ \\
Tempo total & $1.714^{\prime} 29^{\prime \prime}$
\end{tabular}

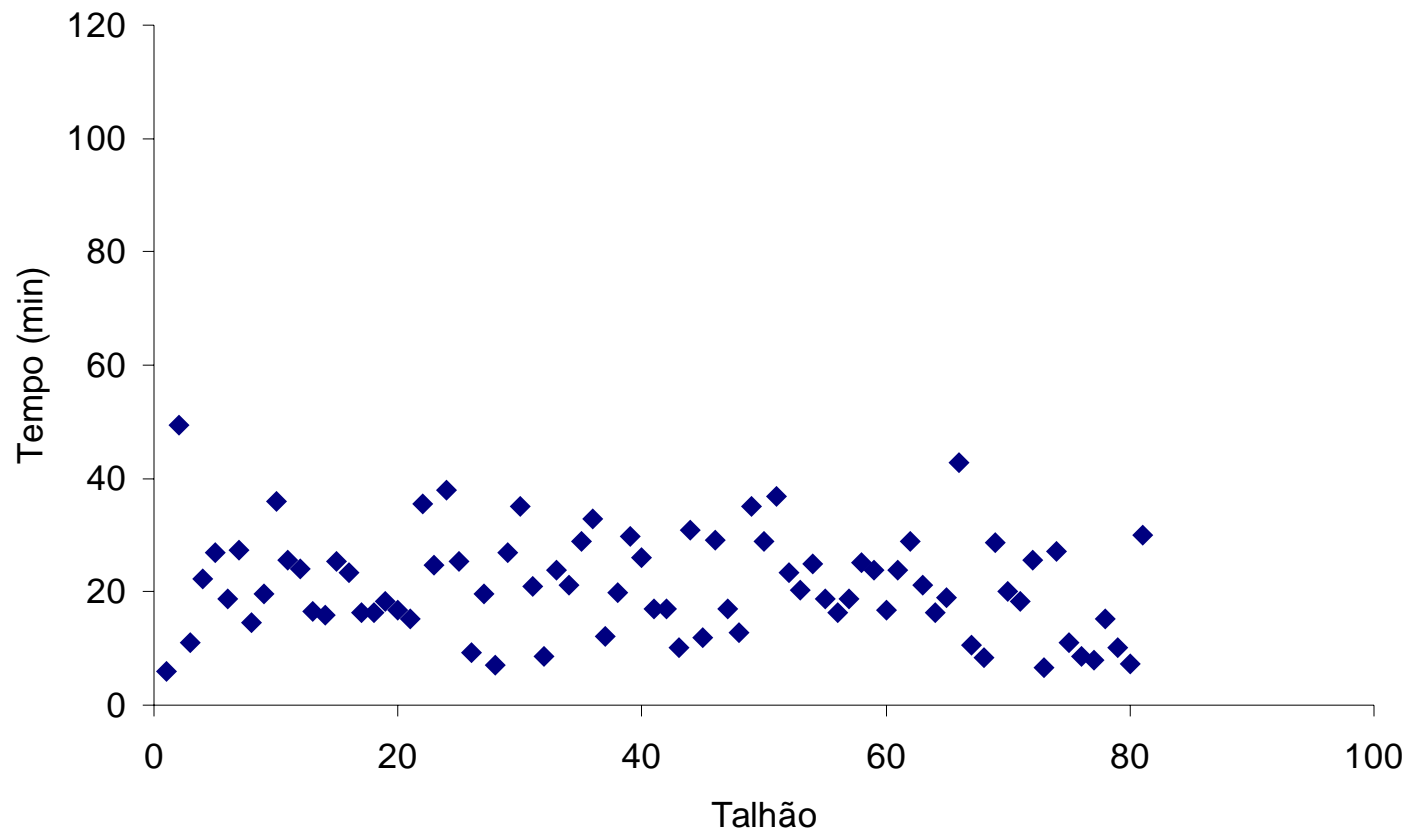

Figura 27 - Tempo estimado de manobra para adubação 


\subsubsection{Eficiência de percurso}

Os talhões analisados apresentaram EP\% baixo (Tabela 11), em média de 69\%. Isso significa que o rendimento das operações agrícolas está sendo pouco aproveitado. Observando-se o gráfico, representado na Figura 28, pode-se perceber que muitos talhões têm rendimento abaixo de $50 \%$, ou seja, o comprimento é menor do que a largura, ocasionando muitas manobras desnecessárias.

Tabela 11. Eficiência de percurso dos 189 talhões observados na área de estudo

\begin{tabular}{cc}
\hline Dados estatísticos & EP\% \\
\hline Média & $69 \%$ \\
Desvio padrão & $13 \%$ \\
Mínimo & $29 \%$ \\
Máximo & $91 \%$ \\
\hline
\end{tabular}

\section{EP\%}

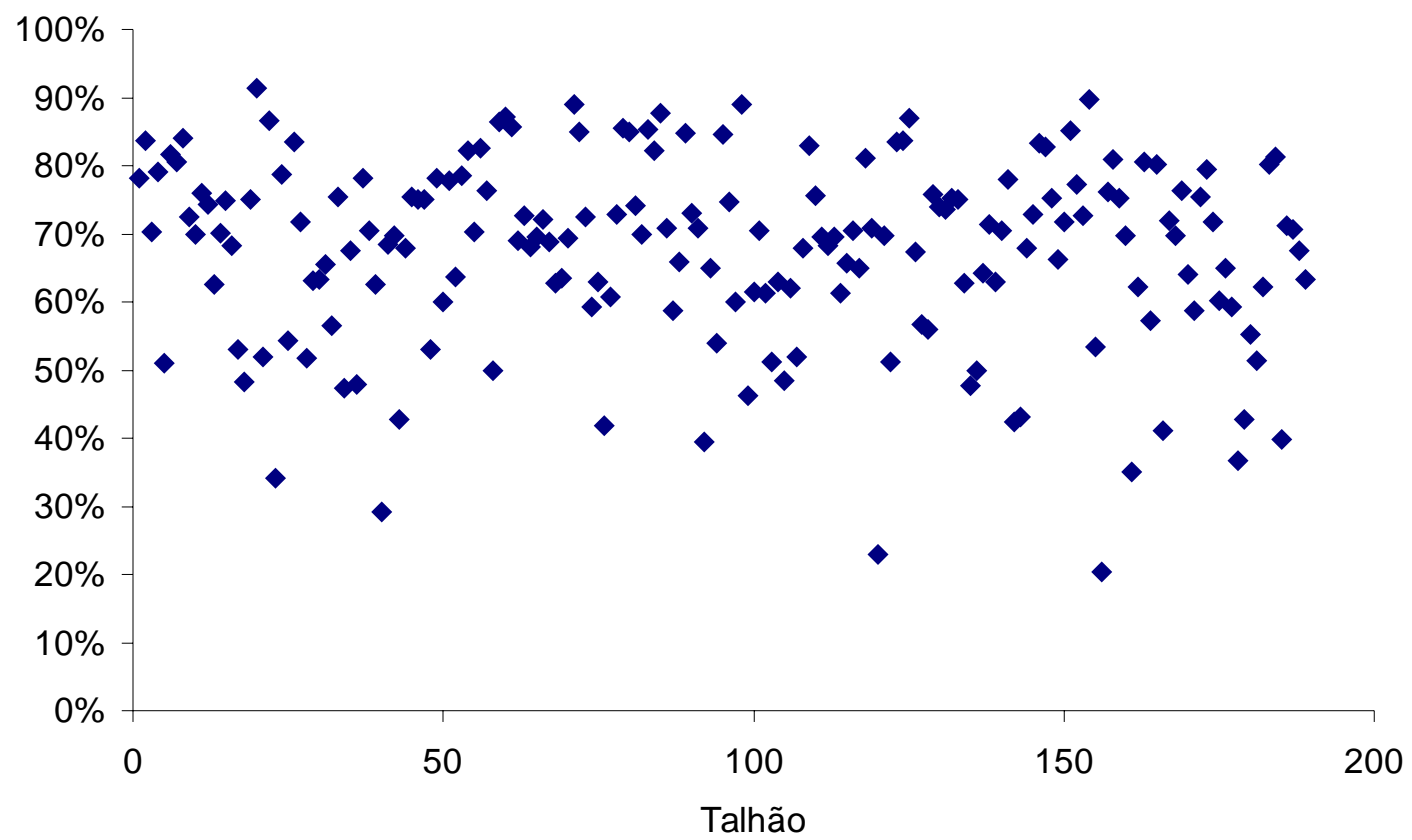

Figura 28 - Eficiência de percurso dos talhões presentes na área de estudo 


\subsection{Cenários}

\subsubsection{APP}

A proposta contida neste projeto leva em consideração os termos da Lei Federal 4.771/65 de 15 de setembro de 1965, que dispõe sobre a ocupação das Áreas de Preservação Permanente. Dessa maneira foi feito todo o planejamento de modo a proporcionar a recomposição da mata ciliar, considerando uma faixa de largura ao longo de todos os canais de drenagem, conforme o disposto na Lei em vigor, que regulamenta uma faixa de 30 metros.

Com a metodologia empregada a Área de Preservação Permanente seria de 334,23 ha.

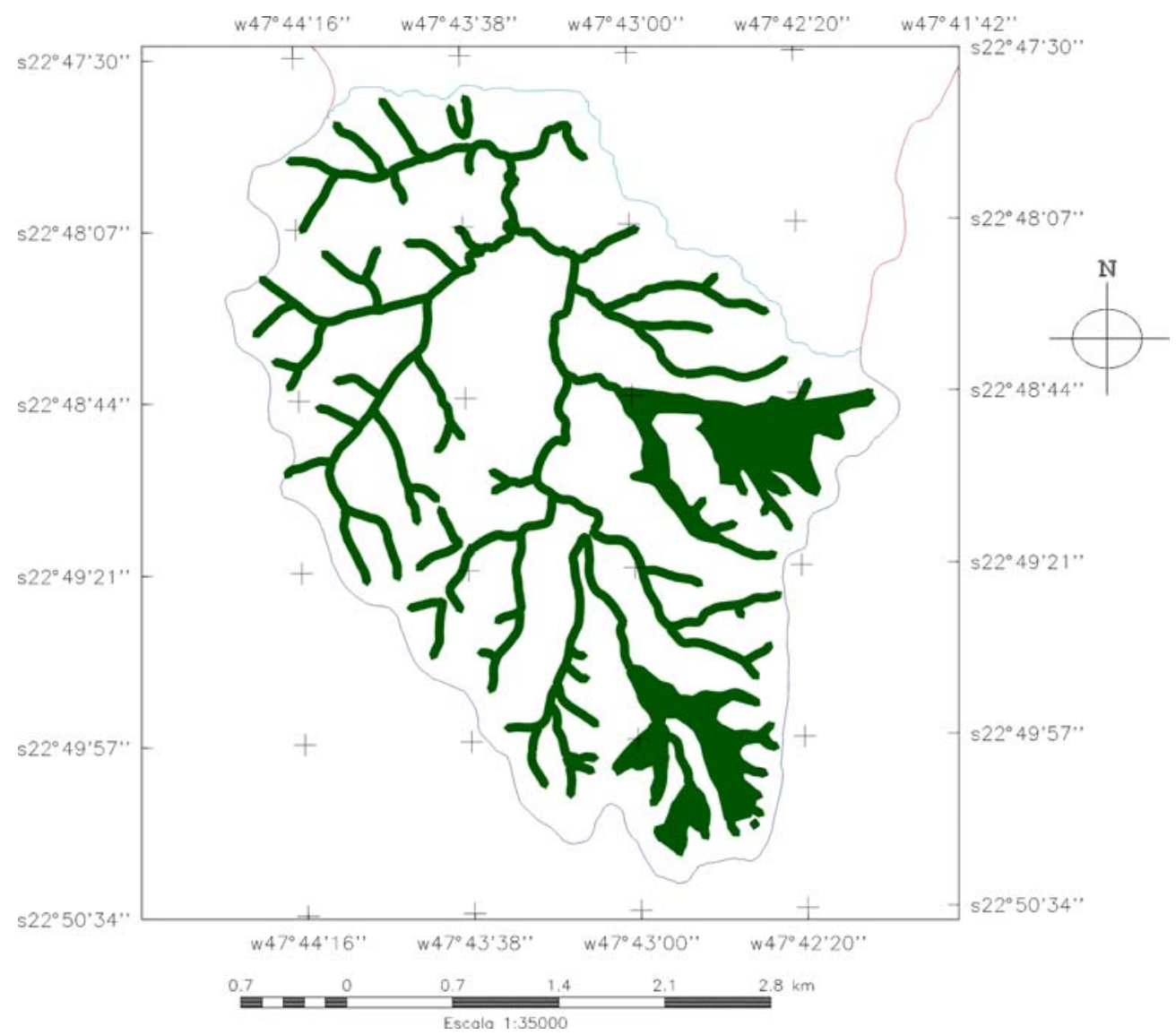

Figura 29 - Cenário de Área de Preservação Permante (APP) 


\subsubsection{Mapa temático de aptidão}

Foi utilizado um algoritmo em LEGAL para a determinação da aptidão, de acordo com as classes propostas por de Biasi (1991). Os valores são apresentados na Tabela 12 e a representação gráfica na Figura 30.

Tabela 12. Aptidão em relação à mecanização

\begin{tabular}{cc}
\hline Classe & Área (ha) \\
\hline A e Hidromórficos & 91,25 \\
B: (3 a 6\%) & 245,56 \\
C: $(6$ a 12\%) & 174,658 \\
D e E: (>12\%) & 14,06 \\
Area total das classes & 525,52 \\
\hline
\end{tabular}

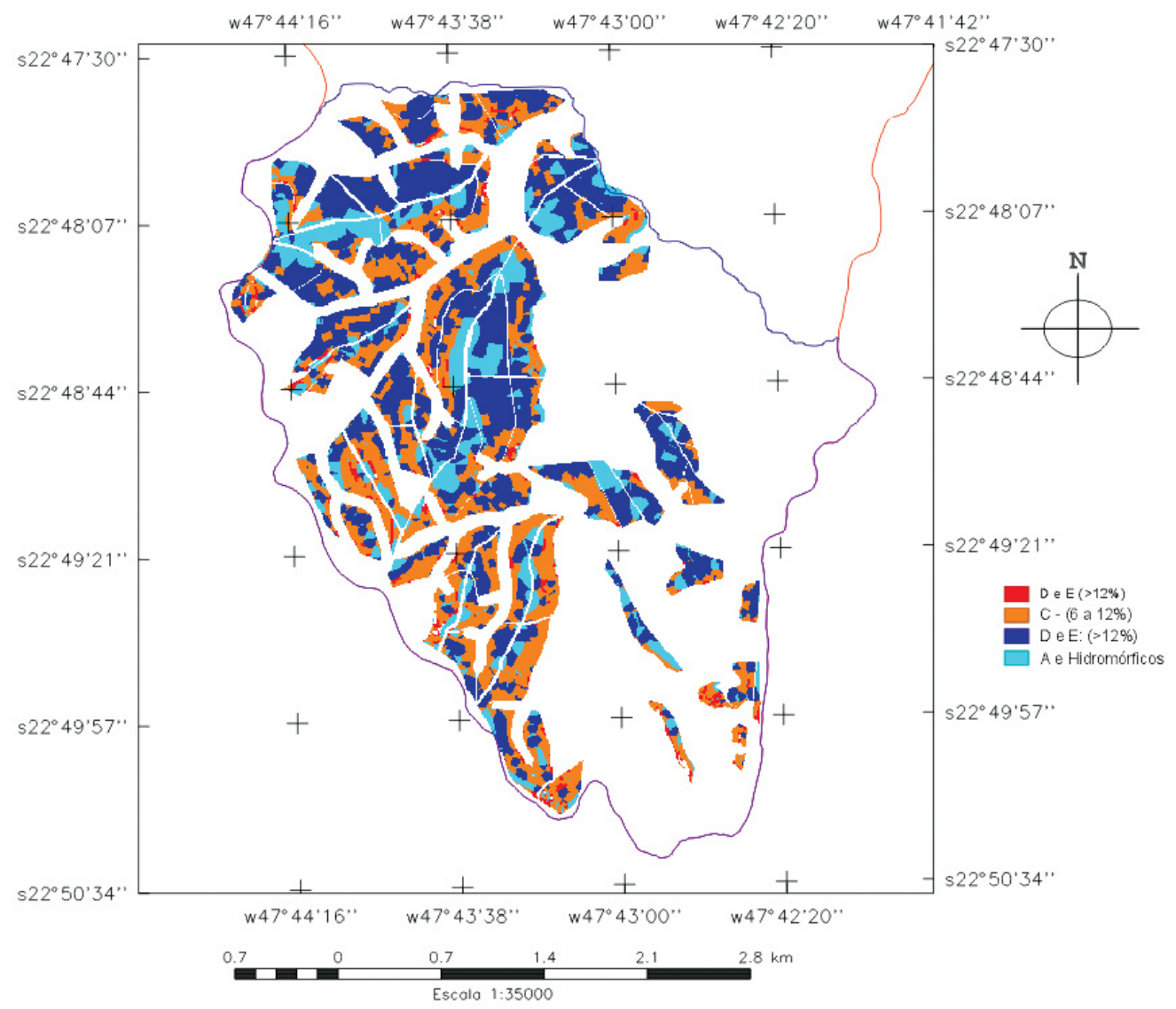

Figura 30 - Mapa de aptidão do modelo proposto 


\subsubsection{Carreadores e estradas vicinais}

Utilizando-se como base os mapas de declividade, curvas de nível, assim como os pontos de escoamento da produção, os carreadores foram traçados de modo a ficarem na perpendicular das maiores declividades. As estradas que circundam a bacia escoam a produção para a usina Santa Helena. Com os critérios adotados, o comprimento total dos carreadores e das estradas seria de $43,86 \mathrm{Km}$.

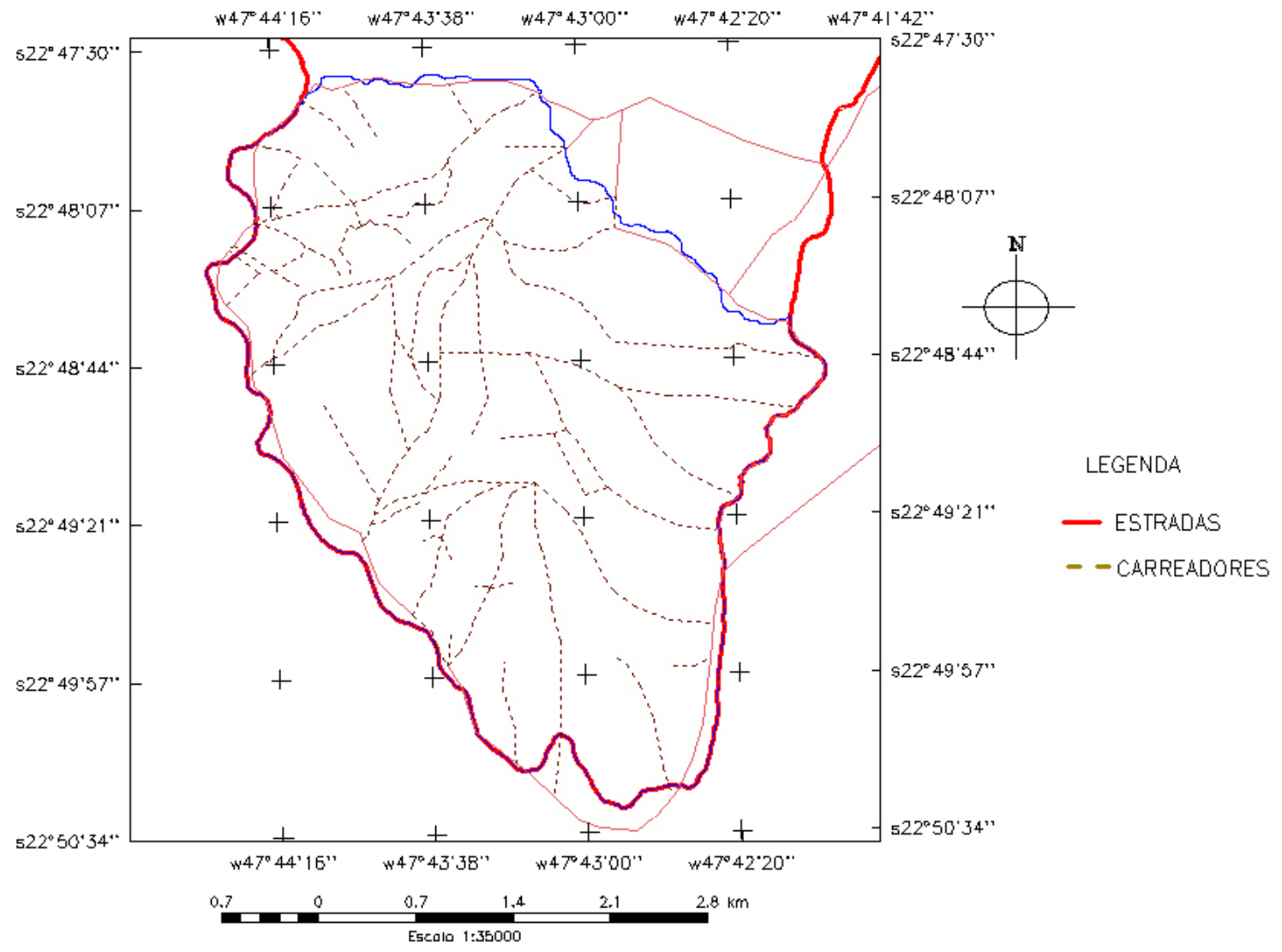

Figura 31 - Alternativa de traçado de carreadores ao modelo atual 


\subsubsection{Talhões}

De acordo com Furlani Neto (1994) os seguintes critérios foram utilizados:

- alteração no comprimento dos talhões, de 200 a 300 m e que precisam ser modificados para $400 \mathrm{~m}$ ou mais para aumentar o rendimento das colhedoras, ocasionado pela redução das manobras de cabeceira e estabilização da velocidade média;

- alterações na forma de se fazer a sulcação, que devem seguir paralelas às curvas de nível, evitando-se a presença dos "bicos", que implicam em aumento de manobras.

Com esses parâmetros, os talhões foram projetados (Figura 32). Os valores obtidos são mostrados na Tabela 13 e sua representação na forma gráfica na Figura 33.

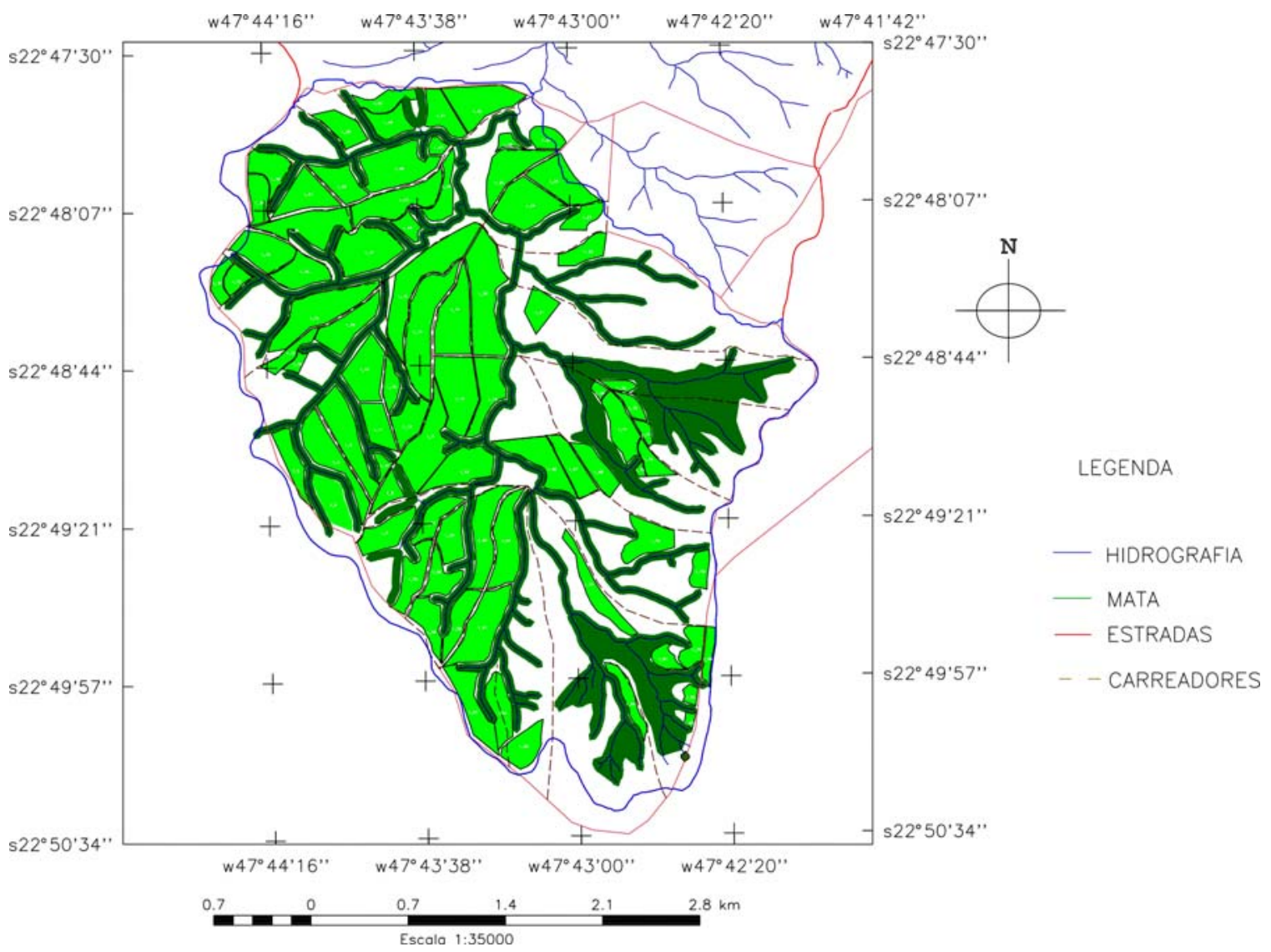

Figura 32 - Formato dos talhões propostos 
Tabela 13. Tamanho dos talhões propostos

\begin{tabular}{cc}
\hline Critérios & Área (ha) \\
\hline Média & 5,85 \\
Mínimo & 0,54 \\
Máximo & 17,81 \\
Total & 528,52 \\
\hline
\end{tabular}

\section{CENÁRIO DE TALHÕES}

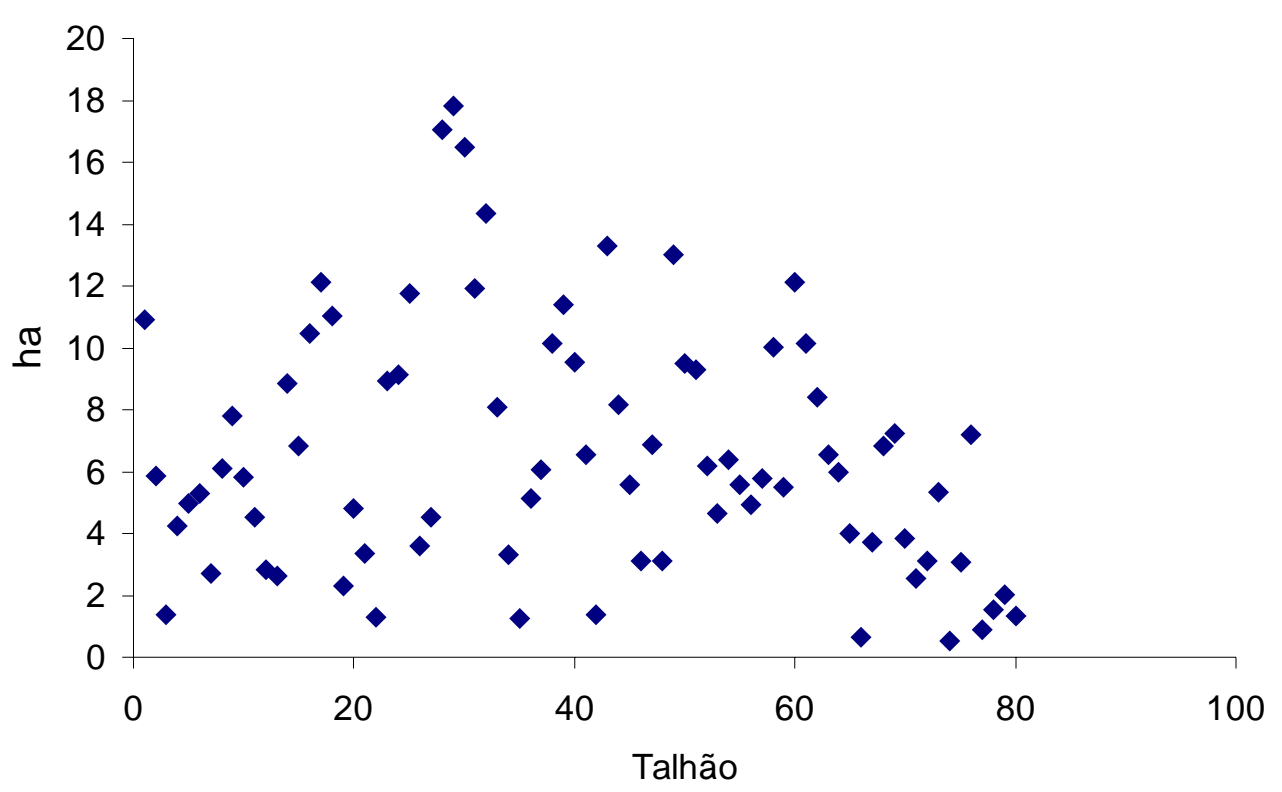

Figura 33 - Tamanho estimado dos talhões projetados 


\subsubsection{Intersecção entre propriedades e talhões}

Foi criado um algoritmo em LEGAL para a determinação da intersecção entre talhões e propriedades, com o objetivo de identificar as propriedades correspondentes aos talhões.

Deste modo o rendimento do talhão seria dividido de acordo com a porcentagem de intersecção em cada propriedade. Um exemplo é mostrado na Tabela 14 e na Figura 34

Tabela 14. Exemplo da aplicação do algoritimo em LEGAL: Área de três talhões presentes na propriedade 119

\begin{tabular}{cc}
\hline $\mathbf{N}^{\mathbf{0}}$ do talhão & Área (ha) \\
\hline 12 & 1,1 \\
11 & 4,34 \\
10 & 4,72 \\
Área total das classes: & 10,17 \\
\hline
\end{tabular}

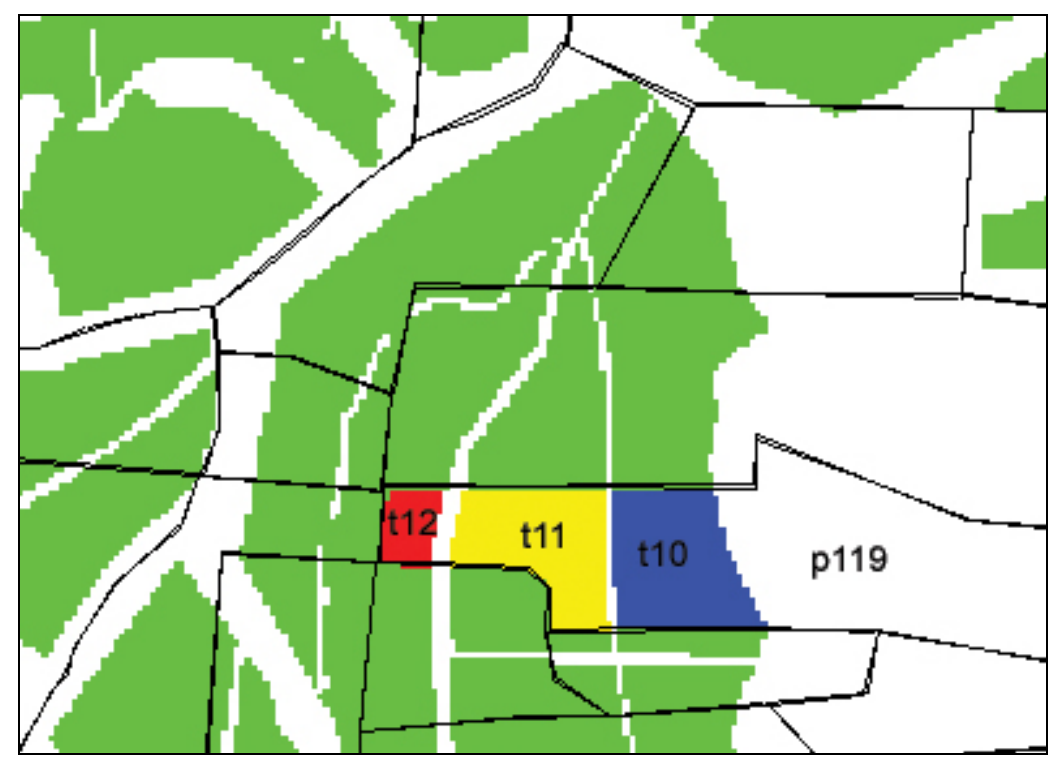

Figura 34 - Área de três talhões que tem intersecção com uma propriedade 


\subsubsection{Tempo de manobra}

\subsubsection{Adubação}

O tempo gasto com manobras nas cabeceiras dos talhões (Tabela 15) para a operação de adubação foi estimado com base nos ensaios de campo. A representação gráfica é apresentada na Figura 35.

Tabela 15. Tempo estimado com manobras de cabeceira para a operação de adubação, no cenário dos 81 talhões propostos

\begin{tabular}{cc}
\hline Dados estatísticos & Tempo (min) \\
\hline Média & $21^{\prime} 17^{\prime \prime}$ \\
Mínimo & $5^{\prime} 57^{\prime \prime}$ \\
Máximo & $49^{\prime} 30^{\prime \prime}$ \\
Desvio Padrão & $8^{\prime} 58^{\prime \prime}$ \\
Tempo total & $1.714^{\prime} 29^{\prime \prime}$ \\
\hline
\end{tabular}

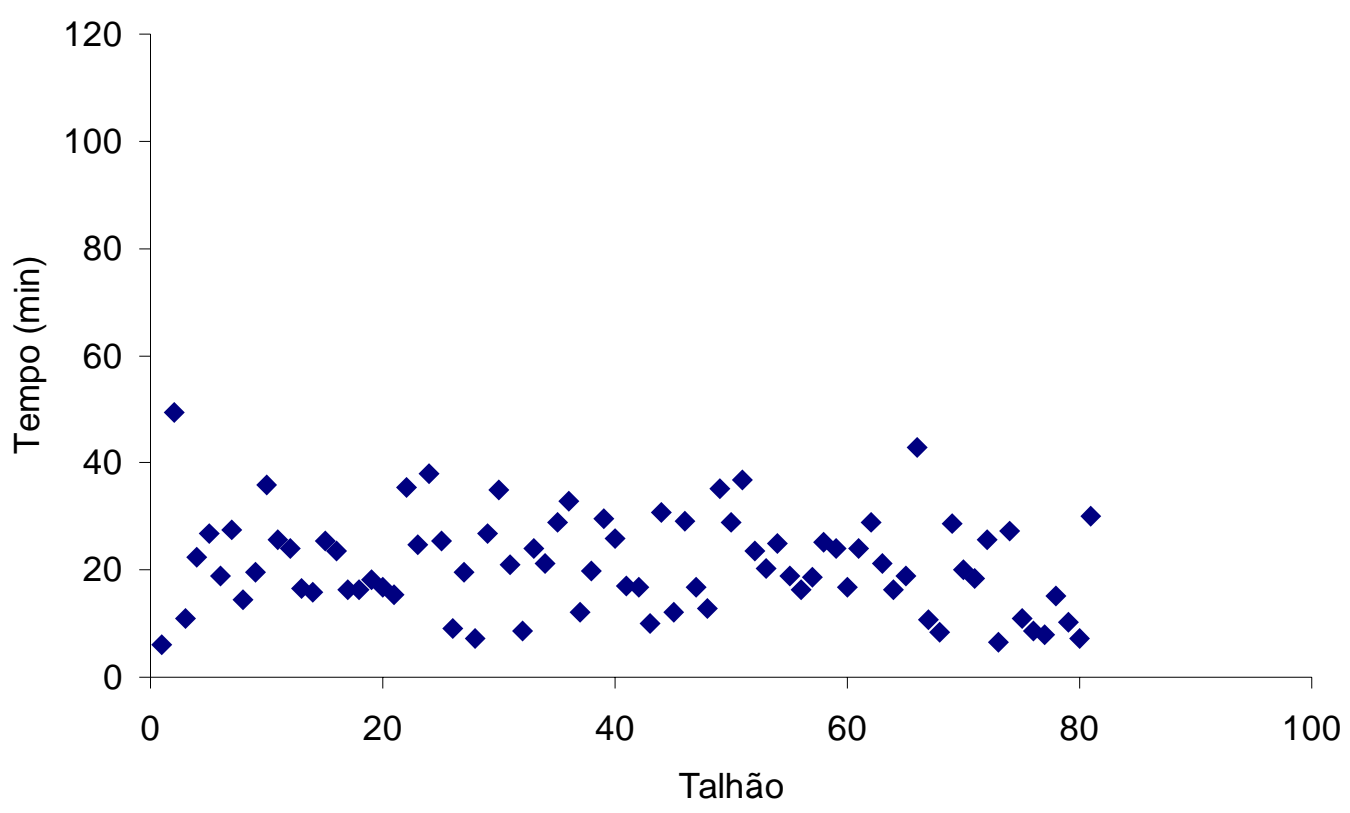

Figura 35 - Tempo estimado de manobra para o cenário de talhões propostos - operação: adubação 


\subsubsection{Aplicação de herbicida}

O tempo gasto com manobras nas cabeceiras dos talhões (Tabela 16) para a operação de aplicação de herbicida foi estimado com base nos ensaios de campo. A representação gráfica é apresentada na Figura 36.

Tabela 16. Tempo de manobra estimado para aplicação de herbicida nos 81 talhões projetados com os critérios propostos

\begin{tabular}{cc}
\hline Dados estatísticos & Tempo (min) \\
\hline Média & $43^{\prime} 9 "$ \\
Desvio padrão & $18^{\prime} 17^{\prime \prime}$ \\
Mínimo & $12^{\prime} 8^{\prime \prime}$ \\
Máximo & $60^{\prime} 55^{\prime \prime}$ \\
Soma & $3495^{\prime} 52^{\prime \prime}$ \\
\hline
\end{tabular}

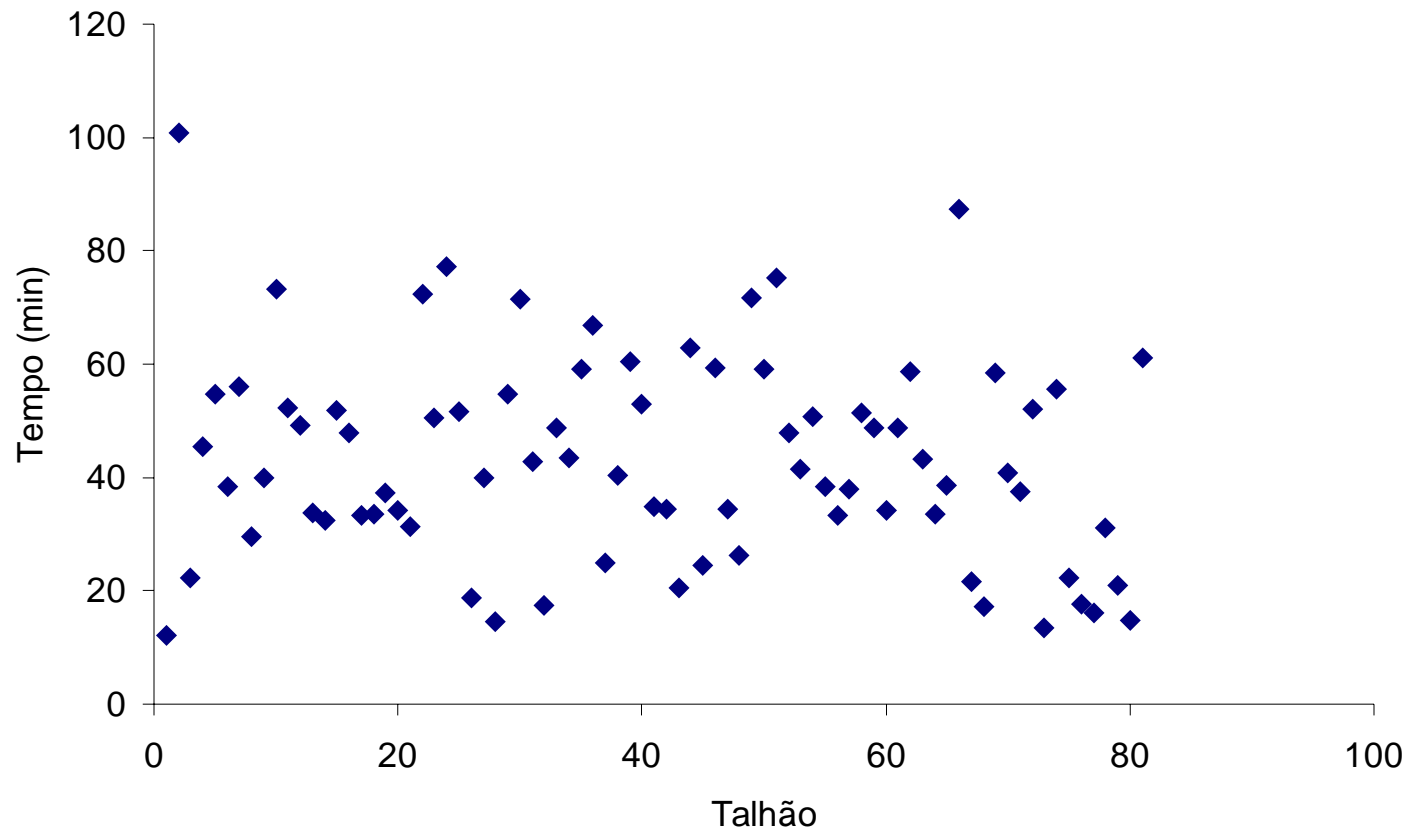

Figura 36 - Cenário de tempo de manobra para aplicação de herbicida 


\subsubsection{Cenário de eficiência de percurso}

A eficiência de percurso, termo proposto por Mialhe (1974), representa a relação da largura do implemento com a largura do talhão, e tem relação direta com o tempo gasto para a execução de determinada operação agrícola. Neste estudo, foi proposto um cenário de talhões de modo a aumentar a eficiência de percurso, em uma área específica, e compara-lo com a situação real de campo. Os principais valores estatísticos são apresentados na Tabela 17 e a representação gráfica na Figura 37.

Tabela 17. Estatística descritiva da EP\% no cenário proposto para 81 talhões

\begin{tabular}{cc}
\hline Dados estatísticos & Eficiência de percurso (EP\%) \\
\hline Média & $75 \%$ \\
Mediana & $76 \%$ \\
Desvio padrão & $11 \%$ \\
Mínimo & $42 \%$ \\
Máximo & $96 \%$ \\
\hline
\end{tabular}

CENÁRIO - EFICIÊNCIA DE PERCURSO

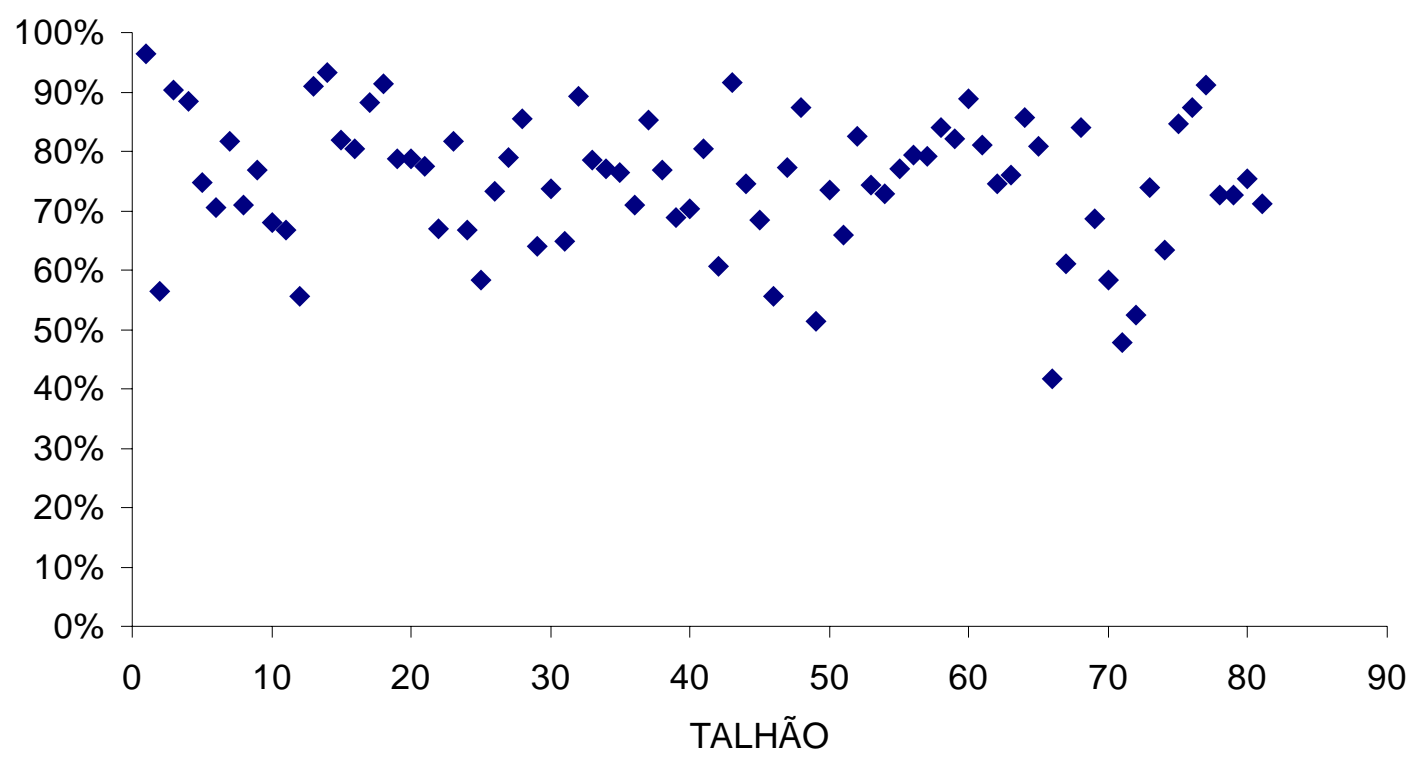

Figura 37 - Eficiência de percurso dos talhões propostos 


\subsection{Análise comparativa}

A situação atual e o cenário proposto foram comparados de acordo com os critérios avaliados neste estudo. Observando-se a Tabela 18, é possível perceber o aumento da eficiência em $8,69 \%$. Com a realização do teste $T$, para dados não pareados, foi constatado que ao nível de significância de 1\%, o valor obtido representa uma melhora significativa.

Tabela 18. Comparação entre o modelo adotado e o cenário proposto

\begin{tabular}{cccc}
\hline Critério & situação atual & $\begin{array}{c}\text { Cenário } \\
\text { proposto }\end{array}$ & Variação \% \\
\hline Área total & $464,00 \mathrm{ha}$ & $525,52 \mathrm{ha}$ & $+13,35$ \\
D e E - Inapta & $16,70 \mathrm{ha}$ & $14,06 \mathrm{ha}$ & $-15,80$ \\
\hline B - Mecanizável (terreno ondulado) & $153,68 \mathrm{ha}$ & $174,66 \mathrm{ha}$ & $+13,65$ \\
C - Mecanizável (terreno suave ondulado) & $207,73 \mathrm{ha}$ & $245,56 \mathrm{ha}$ & $+18,21$ \\
Tempo de manobra / Adubação & $50 \mathrm{~h}$ & $29 \mathrm{~h}$ & $-42,00$ \\
Tempo de manobra / Aplicação de herbicida & $102 \mathrm{~h}$ & $58 \mathrm{~h}$ & $-43,13$ \\
Dias de trabalho (considerando jornada diária & 19 & 10 & $-47,36$ \\
de 8 h) & & & $+8,69$ \\
Eficiência de percurso & $69 \%$ & $334,23 \mathrm{ha}$ & $+178,36$ \\
Vegetação / APP & $120,07 \mathrm{ha}$ & $43,86 \mathrm{Km}$ & $-62,01$ \\
\hline
\end{tabular}




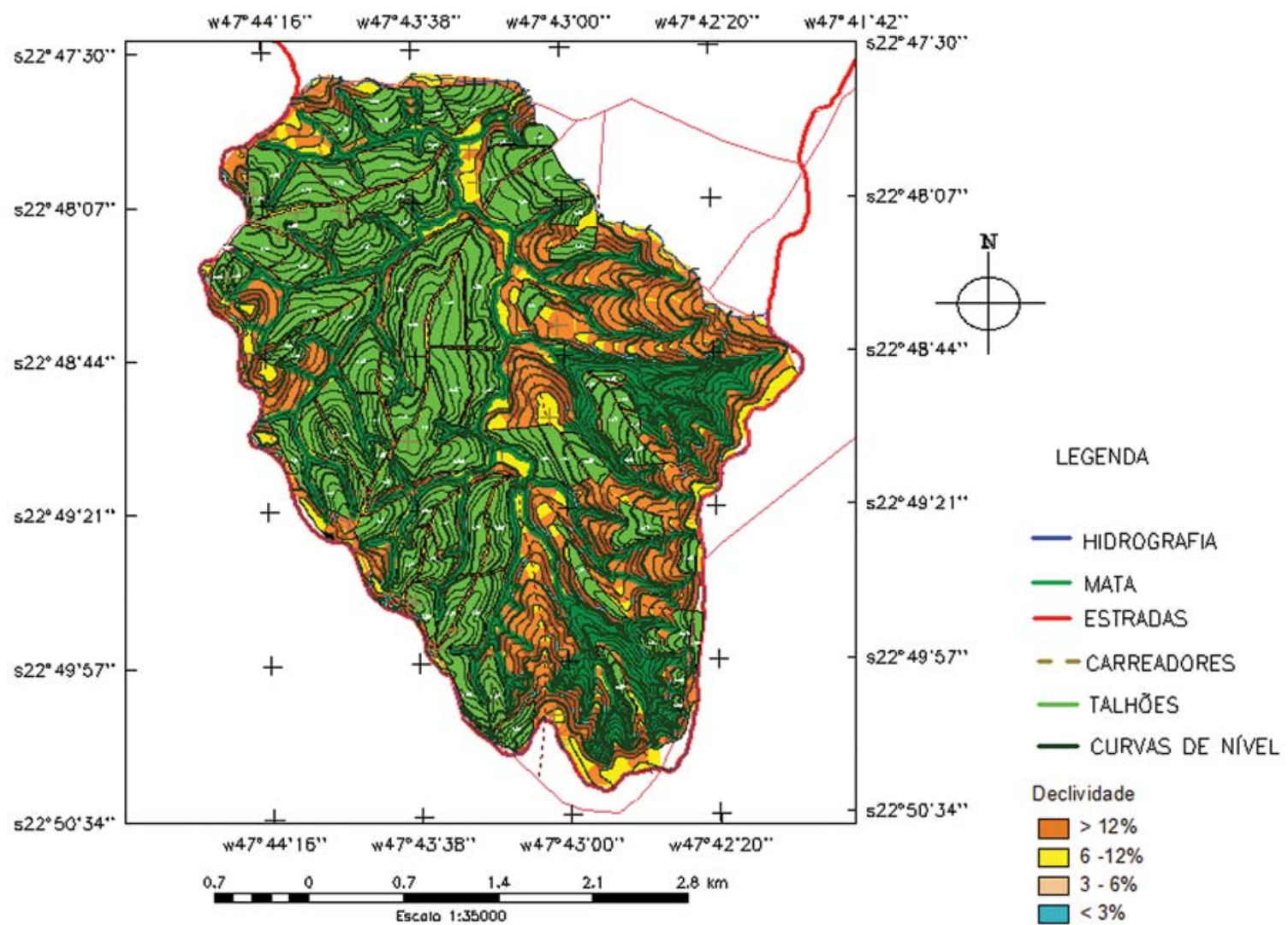

Figura 38 - Sobreposição das camadas, declividade, cenários de carreadores, APP, hidrografia e cenário de talhões 


\section{CONCLUSÕES}

O presente trabalho alcançou com êxito seus objetivos. A geometria dos talhões, assim como o traçado dos carreadores tem uma influência significativa no tempo de manobra (relacionados com a eficiência das duas operações agrícolas estudadas), no comprimento total dos carreadores e estradas vicinais assim como na área cultivada. Com metodologia adotada foi possível avaliar uma região canavieira e propor critérios para a elaboração de cenários que possam contribuir para:

- aumentar a eficiência de percurso, reduzindo o tempo de manobra nas cabeceiras, possibilitando economia em horas/máquinas;

- reduzir o comprimento total dos carreadores, de modo a diminuir o consumo de combustível;

- diminuir a compactação do solo, pela redução do número manobras e de passadas nas operações agrícolas;

- aumentar a área produtiva, pela diminuição da área com carreadores e estradas vicinais;

- localizar áreas potenciais para Preservação Permanente, referente à mata ciliar e a declividade permitida pelo código florestal vigente. 


\subsection{Estudos futuros}

Com a base de dados elaborada, ela pode ser utilizada para as seguintes disciplinas:

- Logística: Com a criação do roteirizador, a dinâmica de transporte e armazenagem de cana pode ser aprofundada em ambiente de SIG's;

- Economia Agroindustrial: Cálculos econômicos do ciclo da cultura da cana-de-açúcar, considerando outras operações agrícolas, com os recursos de SIG's;

- Sensoriamento Remoto: Para determinação de ambientes de produção por sensores orbitais, para a alocação dos talhões de acordo com as propriedades físicas, químicas e geométricas;

- Máquinas Agrícolas: A realização de outros ensaios de Máquinas Agrícolas com técnicas de geoprocessamento;

- Agricultura de Precisão: A divisão em zonas de manejo, assim como aplicações em taxas variáveis devem considerar a topografia e a geometria dos talhões, visando a otimização de recursos. A utilização destes outros elementos pode agregar conhecimento aos estudos de Agricultura de Precisão.

- Legislação florestal e seqüestro de carbono: Estudo para alocação de reserva legal e APP em microbacia e regiões canavierias. 


\section{REFERÊNCIAS BIBLIOGRÁFICAS}

ANTUNES, L.M.; ENGEL, A. A informática na agropecuária. Guaíba: Agropecuária, 1996. $175 p$.

ARONOFF, S. Geographic information systems: a management perspective. Ottawa: WDL,1989. 294 p.

ARRUDA, J.J.A. História: moderna e contemporânea. São Paulo: Ática, 1996. 472p.

ASCOUGH, J.C.; HOAG, D.L.; FRASIER, W.M.; McMASTER, G.S. Computer use in agriculture: an analysis of great plains producers. Computers and Electronics in Agriculture, v. 23, p. 189-204, 1999.

ASSAD, E.D.; SANO,E.E. Sistema de Informações Geográficas: aplicações na agricultura. Brasília: EMBRAPA, CPAC, 1993. 274p.

BALSADI, O.V. A demanda regional da força de trabalho agrícola no Estado de São Paulo e sua sazonalidade, 1994-94. Informações Econômicas, v. 25, n. 6, p.19-30, jun, 1995.

BARBOSA, C.C.F. Álgebra de mapas e suas aplicações em sensoriamento remoto e geoprocessamento. São José dos Campos, 1997. 152p. Dissertação (Mestrado) - Instituto Nacional de Pesquisas Espaciais.

BERNARDI, J.V.E.; LANDIM, P.M.B. Aplicação do Sistema de Posicionamento Global (GPS) na coleta de dados. http://www.rc.unesp.br/igce/aplicada/textodi.html. (20 out. 2002. 
BERTOLINI, J.; DRUGOWICH M.I.; LOMBARDI NETO, F.; BENATTI JUNIOR, R. Conclusões gerais das pesquisas sobre conservação do solo no Instituto Agronômico. Campinas: Instituto Agronômico, 1972. 56 p. (IAC. Circular, 20).

BINS, L.S.; ERTHAL, G.J.; FONSECA, L.M.G. Um método de classificação não supervisionado por regiões. In: SIMPÓSIO BRASILEIRO DE COMPUTAÇÃO GRÁFICA E PROCESSAMENTO DE IMAGENS, 6., Recife, 1993. Anais. Recife: SBC; UFPe, 1993. v.2, p.65-68.

BINS, L.S.;. FONSECA, L.M.G ERTHAL, G.J; II, F.M. Satellite imagery segmentation: a region growing approach (compact disc) In: SIMPÓSIO BRASILEIRO DE SENSORIAMENTO REMOTO, 8., Salvador, 1996. Anais. São José dos Campos: INPE, 1996.

BLITZKOW, D. Navstar/GPS: um desafio tornado realidade. In: SIMPÓSIO BRASILEIRO DE GEOPROCESSAMENTO, 3., São Paulo, 1995. Anais. São José dos Campos, 1995.

BRASIL. Leis, Decretos, etc. Decreto Lei N 4.771, de 15 de setembro de 1965. Código Florestal Brasileiro. Diário Oficial da República Federativa do Brasil, Brasília, 16 de set. 1965.

BRASIL. Ministério da Agricultura, Pecuária e Abastecimento. Japão quer importar álcool de novas áreas agrícolas do Brasil.

http://extranet.agricultura.gov.br/pls/pubacs_cons/!ap_detalhe_noticia_cons?p_id_publicaca o=4455. (22 out. 2003).

BRASIL. RADAMBRASIL: folha SF. 23 Rio de Janeiro e folha SF. 24 Vitória; geologia, geomorfologia, vegetação, uso potencial da terra. Rio de Janeiro, 1983. 780p. (Levantamento dos Recursos Naturais, 32).

CÂMARA, G. Modelos, linguagens e arquitetura para banco de dados geográficos. São José dos Campos, 1995. 286 p. Tese (Doutorado) - Instituto Nacional de Pesquisas Espaciais.

CÂMARA, G.; SOUZA, R.C.M.; FREITAS, U.M.; GARRIDO, J.C.P. SPRING: Integrating remote sensing and GIS with object-oriented data modelling. Computers and Graphics, v.15, n.6, p.13-22, July 1996. 
CAMPOS, R.C. Determinação da cor do solo e sua utilização nos teores de hematita.

Piracicaba, 2002. 71p. Dissertação (Mestrado) - Escola Superior de Agricultura "Luiz de Queiroz", Universidade de São Paulo.

COMISSÃO TÉCNICA DE CANA-DE-AÇÚCAR. Relatório preliminar sobre processos de colheita. São Paulo: Secretaria de Agricultura e Abastecimento, 1997.

CONDE, A.J.; JOAQUIM, A.C. Planejamento de talhões pela base física. In: SEMINÁRIO DE TECNOLOGIA AGRONÔMICA, 7., Piracicaba, 1995. Piracicaba: COPERSUCAR, 1995. p.156-160.

CONGRESSO BRASILEIRO DE ECONOMIA E SOCIOLOGIA RURAL, 37., Foz do Iguaçu, 1999. Anais. Foz do Iguaçu: SOBER, 1999.

COURSEWARE. Sistemas de Informações Geográficas.

http://www.prudente.unesp.br/dcartog/arlete/hp_arlete/courseware/intgeo.htm, (10 ago. 2002).

CROSTA, A.P. Processamento digital de imagens de sensoriamento remoto. Campinas: UNICAMP. 1992. 170p.

CRESTANA, M.S.M.; TOLEDO FILHO, D.V.; CAMPOS, J.B. Florestas: sistemas de recuperação com essências nativas. Campinas: CATI, 1993. 60p.

De BIASI, Carta clinográfica: métodos de representação e sua confecção. São Paulo: Geográfica, 1991.

DEMATTÊ, J.A.M; DEMÉTRIO, V.A. Caracterização de solos por padrões de drenagem e sua relação com índices de intemperismo. Pesquisa Agropecuária Brasileira, v.33, n.1, p. 8795, jan.1998.

DEPARTAMENTO DE ESTRADAS E RODAGENS. Manual de revestimento vegetal. São Paulo, 1975. 1v.

DISPERATI, A.A. Obtenção e uso de fotografias aéreas de pequeno formato. Curitiba: UFPR; FUPEF, 1991. 290p. 
EMPRESA BRASILEIRA DE PESQUISA AGROPECUÁRIA. Centro Nacional de Pesquisa de Solos. Sistema brasileiro de classificação de solos. Brasília: Embrapa Produção de Informações; Embrapa Solos, 1999. 412 p.

EMPRESA BRASILEIRA DE PESQUISA AGROPECUÁRIA. Monitoramento por satélites, o Brasil visto do espaço. http://www.cnpm.embrapa.br/. (01 jun. 2003).

FUNDAÇÃO SEADE. Sensor Rural, n.1, set./dez. 1996.

FUNDAÇÃO SEADE. Sensor Rural, n.3, maio/ago. 1997.

FNP CONSULTORIA \& COMÉRCIO. Agrianual 2002: Anuário da agricultura brasileira, São Paulo, 2002. 536p.

FURLANI NETO, V.L Sulcos alternados duplos (SAD) e simples - controle de tráfego na colheita de cana picada. STAB. Açúcar, Álcool e Subprodutos, v. 13, n.4, p.14-16, mar./abr. 1995.

FURLANI NETO, V.L. Colheita mecanizada da cana-de-açúcar. STAB, Açúcar, Álcool e Subprodutos, v. 12, n.3, p.8-9, jan./fev. 1994.

HAN, S.; RAWLINS, S.L.: SHENEIDER, S.M.; EVANS, R.G. Yield mapping with differential GPS. St. Joseph: ASAE, 1995. 6p. (ASAE Paper, PNW95-302).

INSTITUTO NACIONAL DE PESQUISAS ESPACIAIS. Introdução ao sensoriamento remoto: sistema de ajuda do SPRING, São José dos Campos, 2003.

KENNIE, T.J.M; MATEEHEWS, M.C. Remote sensing in civil engineering: New York: John Wiley, 1985. 357p.

LIMA, W.P. Princípios de manejo de bacias hidrográficas. Piracicaba: ESALQ, Departamento de Ciencias Florestais, 1976. 150p.

LETHAM, L. GPS Made easy: using global positioning systems in the outdoors. Seattle: The Mountaineers, 1996. 112 p. 
MACHADO, P.A.L. As 17 Leis ambientais mais importantes do país. http://www.jornal-domeio-ambiente.com.br. (20 jul. 2002).

MAGUIRE, D.J. Na overview and definition of GIS. In: MAGUIRE, D.J.; GOODCHILD, M.F.; RHIND, D.W. Geographical information system. New York: John Wiley. 1991. cap. 1, p. 9-20.

MARCHETTI, D.A.B.; GARCIA, G.J. Princípios de fotogrametria e fotointerpretação. São Paulo: Nobel, 1986. 257p.

MATINELLI, L.A.; SILVA, A.M.; CAMARGO, P.B.; MORETTI, L.R.; TOMAZELLI, A.C.; SILVA, D.M.L.; FISHER, E.G.; SONODA, K.C.; SALOMÂO, M.S.M.B. Levantamento das cargas orgânicas lançadas nos rios do Estado de São Paulo. Biotaneotrópica, v.2, n.2, p.1-18, 2002.

MATHER, P.M. Computer processing of remotely sensed images. Chichester: John Wiley, 1987. 352p.

MATTEO, K.C. Sistemas de Informação Geográfica para monitoramento da cultura de cana de açúcar. São José dos Campos, 1998. Dissertação (Mestrado) - Instituto Nacional de Pesquisas Espaciais.

MIALHE, L.G. Manual de mecanização agrícola. São Paulo: Agronômica Ceres, 1974. 301p.

MIALHE, L.G. Máquinas agrícolas: ensaios \& certificação. Piracicaba: FEALQ, 1996. 716p.

MOLIN, J.P. Agricultura de precisão: o gerenciamento da variabilidade. Piracicaba: o autor, 2001. 83p.

MONICO, J.F.G. Posicionamento pelo NAVSTAR-GPS: descrição, fundamentos e aplicações. São Paulo: Editora UNESP, 2000. 287 p.

NOVO, E.M.L.M. Sensoriamento remoto: princípios e aplicações. 2.ed. São Paulo: Edgard Blusher, 1995. 308p. 
PROJETO PIRACENA. Geoprocessamento. http://www.cena.usp.br/piracena/geopro.htm. (10 jul. 2002).

PENIDO, LR.Técnicas de sensoriamento remoto e SIG aplicadas ao planejamento de uma rodovia, estudo de caso: trecho oeste do Rodoanel Metropolitano de São Paulo. São José dos Campos, 1998. 123p. Dissertação (Mestrado) - Instituto Nacional de Pesquisas Espaciais.

PRADO, H. Manual de classificação de solos do Brasil. Jaboticabal: FUNEP, 1996. 195 p.

REVISTA GLEBA - INFORMATIVO TÉCNICO. Cana-de-açúcar: proteger o ambiente e continuar gerando empregos. Edição Setembro 2001. http://www.cna.org.br/gleba99n/set01/cana.htm. (20 out. 2003).

RICHARDS, J.A. Remote sensing digital image analysis: an introduction. Berlin: SpringerVerlag, 1986. 218p.

RÍPOLI, T.C.C.; BALASTREIRE, L.A. Contribuição ao estudo do sistema de colheita mecanizada de cana-de-açúcar. Brasil Açucareiro, v.87, n4, p.11-17, abr. 1976.

RÍPOLI, T.C.C.: PARANHOS, S.B. Sistemas de colheitas. In: PARANHOS, S.B. (Coord.). Cana-de-açúcar: cultivo e utilização. Campinas: Fundação Cargil, 1987. v.2.

ROSS, J.L.S. Análise empírica da fragilidade dos ambientes naturais e antropizados. Revista do Departamento de Geografia FFLCH-USP, n.8, p.63-74, 1994.

SATURNINO, H.M.; LANDERS, J.N. (Ed.). O meio ambiente e o plantio direto. Goiânia: EMBRAPA, 1997. 116p.

SENTELHAS, P.C.; PEREIRA, A.R.; MARIN, F.R.; ANGELOCCI, L.R.; ALFONSI, R.R.; CARAMORI, P.H.; SWART, S. Balanços Hídricos Climatológicos do Brasil - 500 balanços hídricos de localidades brasileiras. Piracicaba: ESALQ, 1999. 1 CD-ROM

SHEPHERD, I.D.H. Information integration and GIS. In: MAGUIRE, D.J.; GOODCHILD, M. F.; RHINd, D.W. Geographical Information Systems. New York: Jonh Wiley. 1991. cap. 22, p. 337-360. 
SOUZA, P.R.P.; MILLS,J., (Coord.) Conflitos jurídicos, econômicos e ambientais: estratégias para o desenvolvimento de políticas ambientais e de uso do solo. Maringá: Universidade Estadual, 1995. 204p.

SPAROVEK, G. Informações geográficas para a identificação de áreas com potencialidade para colheita de cana crua. In: SEMANA DA CANA-DE-AÇÚCAR DE PIRACICABA, 2., Piracicaba, 1997. Anais. p. 58-60.

SUGAR \& SWEETENER. Situation and Outlook Report. Washington: USDA, 1996.

TOLEDO, P.E.N. Avaliação do potencial de uso das colheitadeiras de cana-de-açúcar no Estado de São Paulo. Informações Econômicas, v. 21, n. 6, p.13-20, jun. 1991,

TOMLIN, D. Geographic information systems and cartographic modeling. New York Prentice Hall, 1990.

VEIGA FILHO, A de A. Fatores explicativos da mecanização do corte na lavoura canavieira paulista. São Paulo: IEA; Secretaria de Agricultura e Abastecimento, 1998.

VEIGA FILHO, A. de A.; SANTOS, Z.A.P.; VEIGA, J.E.R.; OTANI, M.N.; YOSHI, R.L.. Estimativa de desempenho na colheita de cana decorrente da mecanização. STAB, Açúcar, Álcool e Subprodutos, v. 13, n. 4,p.19-21, 1995.

VENTURIERI, A. Segmentação de imagens e lógica nebulosa para treinamento de uma rede neural artificial na caracterização do uso da terra na região de Tucuruí (PA). São José dos Campos, 1996. Dissertação (Mestrado) - Instituto Nacional de Pesquisas Espaciais,

WEICK, C.W. Agribusiness technology in 2010: directions and challenges. Technology in Society, v. 23, p 59-72, 2001.

WOLF, P.R. Elements of photogrammetry. New York: McGraw-Hill,1974. 562p. 